\title{
ESTABILIDADE DA CORREÇÃO DO \\ APINHAMENTO ÂNTERO-INFERIOR NA MÁ \\ OCLUSÃO DE CLASSE II DE ANGLE TRATADA COM A EXTRAÇÃO DE DOIS E QUATRO PRÉ- MOLARES
}

MAURO CARLOS AGNER

BUSATO

Dissertação apresentada à Faculdade de Odontologia de Bauru, Universidade de São Paulo, como parte dos requisitos para obtenção do título de Mestre em Odontologia, área de Ortodontia.

(Edição Revisada)

\section{BAURU}




\section{ESTABILIDADE DA CORREÇÃO DO \\ APINHAMENTO ÂNTERO-INFERIOR NA MÁ \\ OCLUSÃO DE CLASSE II DE ANGLE TRATADA \\ COM A EXTRAÇÃO DE DOIS E QUATRO PRÉ- \\ MOLARES}

MAURO CARLOS AGNER

BUSATO

Dissertação apresentada à Faculdade de Odontologia de Bauru, Universidade de São Paulo, como parte dos requisitos para obtenção do título de Mestre em Odontologia, área de Ortodontia.

(Edição Revisada)

Orientador:Prof. Dr. Guilherme dos Reis

Pereira Janson

BAURU

2003 


\section{Busato, Mauro Carlos Agner}

B96e Estabilidade da correção do apinhamento ântero-inferior na má oclusão de Classe II de Angle tratada com a extração de dois e quatro pré-molares. / Mauro Carlos Agner Busato. - Bauru, 2003.

xxii, 136p. : il. ; $30 \mathrm{~cm}$.

Dissertação (Mestrado) - Faculdade de Odontologia de Bauru. Universidade de São Paulo.

Orientador: Prof. Dr. Guilherme dos Reis Pereira Janson

Autorizo, exclusivamente para fins acadêmicos e científicos, a reprodução total ou parcial desta dissertação/tese, por processos fotocopiadores e outros meios eletrônicos.

Assinatura:

Data:

Comitê de Ética da FOB: $\quad$ Projeto de pesquisa aprovado em 24 de abril de 2002

No do Protocolo: Processo $n^{\circ}$ ODON-3042002 
“...se vocês podem resistir, conscientemente, àmaléfica tendência de errar, à permanente tentação que todos, eu e você, temos para nos enganar, até que tenhamos formado o hábito de oferecer sempre o melhor, seja nos estudos, nas reflexões ou no trabalho clínico, tão bem se desenvolverá nosso caráter que jamais será permitido o erro, e se algum trabalho não for considerado excelente, não haverá descanso até que as imperfeições sejam sanadas". 


\section{MAURO C. AGNER BUSATO}

27 de Julho de 1974

Cascavel-PR

$1992-1996$

$1997-1999$

$2000-2002$

$2001-2003$
Nascimento

Curso de Graduação em Odontologia, pela

Universidade Federal do Paraná.

Curso de Pós-graduação em Ortodontia, ao nível de Especialização, pela Escola de Aperfeiçoamento Profissional, Associação Brasileira de Odontologia, Ponta Grossa-PR.

Professor Auxiliar na Disciplina de Ortodontia, do curso de Graduação em Odontologia da Universidade Estadual do Oeste do Paraná, Cascavel-PR.

Curso de Pós-graduação em Ortodontia, ao nível de Mestrado, Faculdade de Odontologia de Bauru-USP e Universidade Estadual de Londrina-UEL

Associação Brasileira de Odontologia - Paraná, Regional de Cascavel. 
Dedicatórias e Agradecimentos 


\section{Dedicatórias e Agradecimentos}

À Deus, por nos conduzir e dar força na execução dos nossos projetos, $e$ nos mostrar que para quem nele crê, tudo é possível.

Aos meus pais, Mauro e Maria, por sempre estarem presentes e participarem de meus sonhos, incentivando e confiando. A eles dedico este trabalho, lembrandome sempre do exemplo de paciência e amor por eles demonstrados, e que me auxiliarão sobremaneira a vencer os obstáculos e alcançar o objetivo.

À minha irmã, Marcia pelo apoio e incentivo, e servindo de exemplo para mim de amor à Odontologia, dedico este trabalho.

Ao meu avô, José (in memoriam), pelo ensinamento e exemplos de honestidade e amor ao trabalho. 


\section{Ao Prof Dr. Guilherme Janson,}

meu orientador, agradeço os ensinamentos transmitidos, as críticas positivamente dirigidas e a credibilidade em mim depositada. Agradeço também os exemplos de trabalho árduo, da preocupação com a veracidade dos dados obtidos e utilizados neste trabalho, mostrando que a qualidade e seriedade nas pesquisas deve nortear a vida de um Mestre. 
Ao Prof. Dr. José Fernando Castanha Henniques, pela correção dura da didática nos seminários, o que me marcou, e me fez almejar a busca da excelência neste quesito.

Ao, Prof. Dr. Marcos Roberto de Freitas, minha gratidão, pelos primordiais e inestimáveis ensinamentos transmitidos para a minha formação docente e clinica dentro da Ortodontia.

Ao, Prof. Dr. SNewton Expedito de Moraes, agradeço pela confiança depositada, e pela garra demonstrada na viabilização do Mestrado Interinstitucional.

À, Prof $^{a}$. Dra . Maria Fidela de Lima Navarro, meus agradecimentos pela oportunidade de titulação que ànós foi dada, meu sincero reconhecimento. 
À Faculdade de Odontologia de Bauru (FOB - USP) e à UEL (Universidade Estadual de Londrina).

Ao Prof. e Amigo Roberto Bombonatti, pelos ensinamentos (estatística)e incentivos na realização deste trabalho.

Aos colegas de Mestrado Fábio, João Tadeu, Marise, Cabrera, Carlos Eduardo, Nadyr, Cirino, Ricardo, Laélia, pela convivência e troca de experiências.

Aos amigos do curso de mestrado Virgínia, Fátima, Geraldinho, pela amizade presente em momentos por nós compartilhados.

Aos amigos Vlisses Coetho, Emígdio Gimenez, Professores do curso de Especialização em Ortodontia, em especial o Prof. Armando X. Saga (por seu caráter, exemplo e ensinamentos de planejamento e Ortodontia clínica) 
Aos amigos do curso de Graduação,

$$
\text { Lúcio, Meitor e Marcelo pela }
$$

amizade, união, entusiasmo e confiança.

Ao amigo Ivandro e Alexandre pela amizade e incentivo.

Aos meus pacientes do consultório e alunos da UNIOESTE, pela compreensão nos momentos em que tive de me ausentar.

$$
\begin{aligned}
& \text { Aos meus colegas de Disciplina e amigos da VNIOESTE, Prof. } \\
& \text { Amadeu, Prof. Roberto e Prof. Luis Marchi, pela compreensão e } \\
& \text { incentivo nos momentos em que estive ausente. }
\end{aligned}
$$

À minha secretária Juliane, pela paciência em me aguentar nos momentos difíceis nesta caminhada, e pela força dada ao longo destes anos que estamos juntos.

Ao secretário do ITEDES, Ricardo, pela presteza e trabalho que fez possivel o sucesso do MINNTER. 
Ao tio José Ronaldo e a tia Rose, exemplos de trabalho e dedicação à Odontologia, em quem me espelho na busca de ser um bom clínico.

Aos funcionários da Disciplina de Ortodontia da FOB - USP, Cristina, Daniel, Sérgio, Vera e "Tia" Maria pela dedicação, carinho e atenção com que sempre me atenderam.

Ao Prof. José Roberto Lauris pela paciência e orientação no tratamento estatístico deste trabalho.

À Fundação de Amparo à Pesquisa do Estado de São Paulo — FAPESP, pelo apoio financeiro para a realização do curso e viabilização deste projeto.

À todos que direta ou indiretamente estiveram envolvidos no desenvolvimento deste trabalho. 
Sumário 


\section{SUMÁRIO}

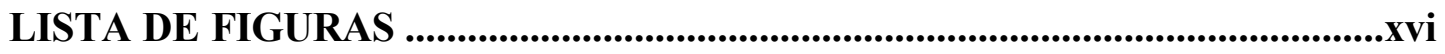

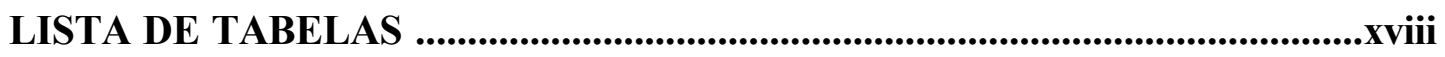

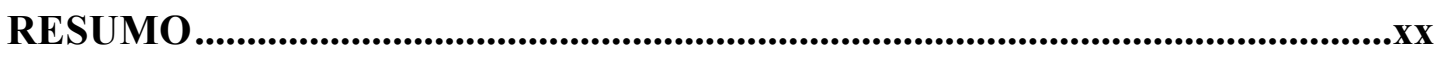

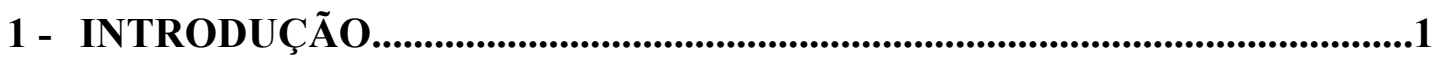

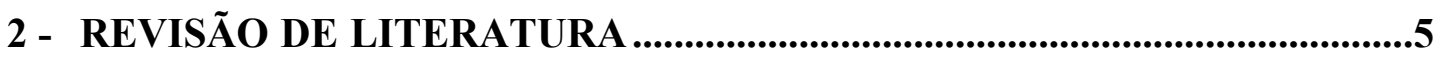

2.1- INDICAÇÃO DE EXTRAÇÕES NA ORTODONTIA ..................................6

2.2 - INDICAÇÕES DE EXTRAÇÕES NA MÁ OCLUSÃO DE CLASSE II.........9

2.2.1 - Indicações de extrações por biprotrusão ...................................................10

2.2.2 - Indicações de extrações por apinhamento ....................................................13

2.2.3 - Indicações de extrações para correção da relação molar.................................15

2.2.4 - Indicações de extrações na má oclusão de Classe II em pacientes com crescimento vertical.............................................................................. 16

2.3 - CONTRA-INDICAÇÕES DE EXTRAÇÕES NA MÁ OCLUSÃO DE



2.3.1 - Contra-indicações de extração na má oclusão de Classe II, divisão 2 ............21

2.4 - RECIDIVA DA CORREÇÃO DO APINHAMENTO INFERIOR .................24

2.4.1 - Amostras tratadas com e sem extrações no arco inferior................................24

2.4.2 - Amostras tratadas com extrações no arco inferior ........................................28

2.4.3 - Amostras tratadas sem extrações no arco inferior............................................

2.4.4 - Apinhamento ântero-inferior e o desenvolvimento da oclusão.........................39 
2.5 - DIMENSÕES DO ARCO INFERIOR (LARGURA E COMPRIMENTO)...40

2.5.1 - Amostras tratadas com e sem extrações no arco inferior. . .40

2.5.2 - Amostras tratadas com extrações no arco inferior ..... .46

2.5.3 - Amostras tratadas sem extrações no arco inferior. .52

2.5.4 - Dimensões do arco inferior e o desenvolvimento da oclusão .56

3 - PROPOSIÇÃO. 59

4 - MATERIAL E MÉTODOS .61

4.1 - MATERIAL .62

4.2 - MÉTODOS. .64

4.2.1 - Medidas no Modelo Inferior. .64

4.2.2 - Análise Estatística .66

5 - RESULTADOS .68

6 - DISCUSSÃO . .74

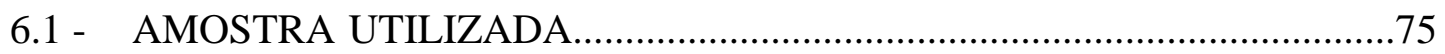

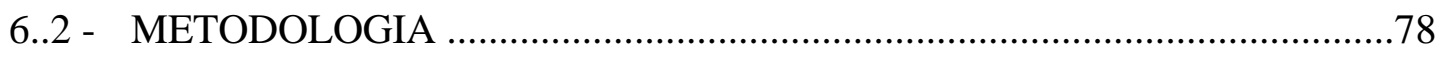



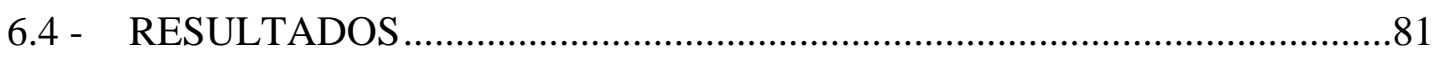

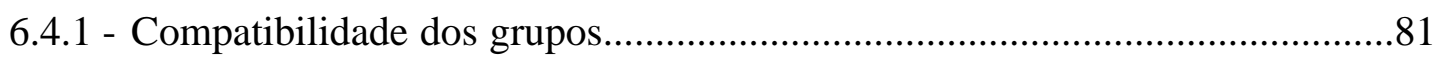

6.4 .2 - Recidiva do apinhamento ântero-inferior.................................................. 82

6.4.3 - Alterações da largura intercaninos durante e após o tratamento Ortodôntico . .90 
6.4.4 - Alterações da largura intermolares durante e após o tratamento

Ortodôntico.

6.4.5 - Alterações do comprimento do arco durante e após o tratamento

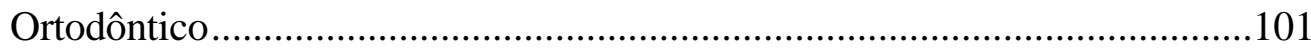

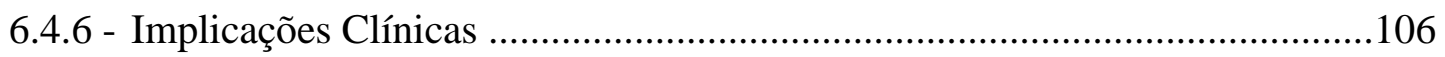



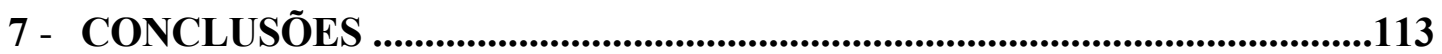

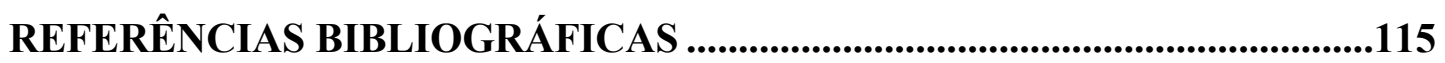

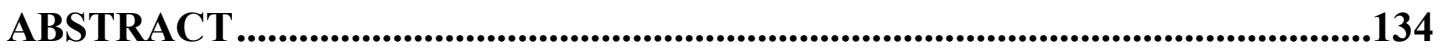

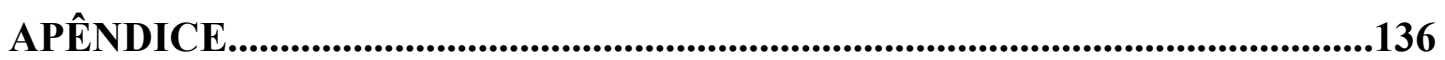


Lista de Figuras 


\section{LISTA DE FIGURAS}

FIGURA 4.1 - Técnica de medição dos modelos, segundo Little ${ }^{65}$. .65

FIGURA 4.2 - Técnica de medição dos modelos, segundo Little ${ }^{66}$. .65 
Lista de Tabelas 


\section{LISTA DE TABELAS}

TABELA 5.1 - Apresentação dos erros casuais (Dahlberg) e dos resultados do teste t para amostras dependentes, do teste intra-examinador .69

TABELA 5.2 - Resultado do teste T independente, entre os grupos 1 e 2 . .70

TABELA 5.3 - Resultado do teste $\mathrm{T}$ independente, entre os grupos 1 e 2 , para as alterações das variáveis nos diferentes período de avaliação . .71

TABELA 5.4 - Resultado do teste $\mathrm{T}$ independente, entre o grupo 1 e o subgrupo 2, com apinhamento inicial compatível

TABELA 5.5 - Resultado do teste T independente, entre o grupo 1 e o subgrupo 2 com apinhamento inicial compatível, para as alterações das variáveis nos diferentes período de avaliação . .73 
Resumo 


\section{RESUMO}

O objetivo desse estudo foi comparar a estabilidade de correção do apinhamento ântero-inferior, em pacientes portadores de má oclusão Classe II de Angle, que haviam se submetido à tratamento ortodôntico com duas ou com quatro extrações de pré-molares. Para tanto, foram selecionados 66 pacientes que apresentavam inicialmente uma má oclusão de no mínimo meia Classe II, e que foram tratados com uma das formas de tratamento propostas. Esses pacientes foram divididos em dois grupos, sendo o grupo 1 (pacientes tratados com extração de dois pré-molares superiores), constituído de 19 pacientes, com idade média de 14,04 anos; e o grupo 2 (pacientes tratados com extração de quatro pré-molares) composto de 47 pacientes, com idade média de 13,03 anos. Para verificação das diferenças entre os grupos da recidiva do apinhamento inferior, utilizou-se o Índice de Irregularidade de Little, medindo-se os modelos referentes às fases pré-tratamento, pós-tratamento, e em média cinco anos após o final do tratamento ativo. Adicionalmente, realizou-se avaliações do comportamento da largura e do comprimento do arco inferior, durante o período do tratamento e pós-tratamento, buscando-se evidenciar possíveis diferenças entre as duas abordagens terapêuticas. As alterações do índice de Little e das dimensões do arco inferior, entre as três fases, também foram comparadas. Os valores foram submetidos à análise estatística pelo teste $\mathrm{t}$ independente para comparar as variáveis entre os grupos. Os resultados demonstraram que não houve diferença entre os dois grupos para a recidiva pós-tratamento do apinhamento inferior, bem como para as mudanças pós-contenção no comprimento e na largura do arco inferior. Portanto, pode-se esperar o mesmo grau de recidiva da correção do 
apinhamento inferior em pacientes com má oclusão de Classe II, quando o tratamento é conduzido com extrações de dois pré-molares superiores, ou quando realizado com extrações de quatro pré- molares. 
1-Introdução 


\section{1 - INTRODUÇÃO}

A estabilidade a longo prazo do tratamento ortodôntico, talvez seja, dentre as metas a serem alcançadas por esta terapia, a de maior dificuldade de obtenção $^{105,129,67,72}$. ANGLE ${ }^{3,4}$, em 1907, já afirmava que as recidivas ocorrerão se os dentes não permanecerem, ao final do tratamento, em oclusão normal.

As recidivas que podem ocorrem, são das mais diversas naturezas, tanto interarcos, como intra-arcos ${ }^{82}$, sendo que a instabilidade mais notada é a volta de irregularidades na região ântero-inferior, pois esta é em geral a característica mais freqüente da má oclusão ${ }^{1}$,e aquela que, na maioria das vezes, traz o paciente ao consultório para sua correção ${ }^{66,131}$. Desta forma, o sucesso ou a falha de um caso ortodôntico, é freqüentemente interpretado sob a ótica da estabilidade pós-tratamento dos incisivos inferiores, pois o paciente tende a priorizar quase que exclusivamente o alinhamento de seus incisivos e caninos $^{26,131}$, muito embora, as mudanças nas relações dentárias, após o tratamento ortodôntico, não indicam necessariamente uma recidiva $^{128}$.

Estudos de proservação de casos tratados, têm mostrado que uma melhoria na dentição pode ser alcançada, porém infelizmente a irregularidade de incisivos, particularmente na mandíbula, na maioria das vezes, se desenvolve após a fase de contenção ${ }^{33,67,74,102,105}$. Os ortodontistas têm observado que os resultados de seus tratamentos são susceptíveis às mudanças, em níveis no mínimo similares a 
oclusões não tratadas, havendo desta forma limitações a longo prazo na estabilidade das correções obtidas ${ }^{129}$.

Os trabalhos da Universidade de Washington $^{5,6,33,34,49,67,68,69,70,71,72,73,80,100,113,115}$, atestam a dificuldade de se manter o alinhamento ântero-inferior, independente da filosofia e técnica de tratamento, gênero e idade do paciente, sendo que a longo prazo, 20 anos em média pós-tratamento, apenas 30\% dos pacientes que tinham alinhamento ântero-inferior aceitável ao final do tratamento(índice de Little igual ou menor que 3,5 mm), permaneceram com índices considerados clinicamente satisfatórios. Desta forma o alinhamento a longo prazo é variável e imprevisível ${ }^{72}$.

Com relação a abordagem da má oclusão de Classe II de Angle, esta pode ser tratada com e sem extrações de dentes permanentes, dependendo das características inerentes ao caso ${ }^{6,14,17}$. No caso de optar-se por extrações de prémolares, esta podem envolver extrações de dois ${ }^{87}$ ou quatro pré-molares ${ }^{6,14,17}$. Para BRAMBILLA $^{22}$, a abordagem da classe II com extração de dois pré-molares, permite obter melhores relações oclusais ao final do tratamento, do que a abordagem com extrações de quatro pré-molares. Isso nos remete à debates seculares da ciência ortodôntica, pois se por um lado quando são extraídos somente dois pré-molares superiores, há um melhor resultado oclusal final, e em decorrência desta melhor oclusão de finalização, poderia se esperar melhor estabilidade ${ }^{3,4}$, por outro, na abordagem sem extrações no arco inferior, são suscitadas expansões do arco, tanto no sentido transversal (distância intercaninos e intermolares), bem como no sentido ântero-posterior (vestibularização de incisivos), o que deixaria os casos assim 
tratados, com uma maior suscetibilidade à recidiva no apinhamento inferior $^{19,120,127,128}$. A corrente científica que advoga a abordagem com extração de quatro pré-molares, justifica as extrações no arco inferior, como forma de melhor posicionar os incisivos sobre o osso basal (verticalização) ${ }^{78,127,128}$, obtendo-se assim a estabilidade como meta final do tratamento ortodôntico, muito embora se saiba, através de estudos de pós-contenção de casos tratados com extrações de quatro prémolares, que estes apresentaram recidiva do alinhamento ântero-inferior a longo $\operatorname{prazo}^{68,72}$.

Desta forma, resolveu-se realizar esta pesquisa, no intuito de comparar a estabilidade da correção do apinhamento ântero-inferior, de dois grupos de pacientes portadores de má oclusão Classe II de Angle, tratados com a extração de quatro e dois pré-molares, buscando-se avaliar possíveis diferenças na recidiva do apinhamento pós-tratamento, bem como comparar o comportamento, durante o tratamento e na pós-contenção, das medidas do comprimento de arco inferior, distância intercaninos e distância intermolares, para os dois grupos em questão. 
2-Revisão de Literatura 


\section{2 - REVISÃO DE LITERATURA}

Com o objetivo de ficilitar a compreensão, a revisão de literatura foi desenvolvida de modo a fornecer informações sobre a indicação da extrações na Ortodontia em geral, e especificamente para a correção da má oclusão de Classe II. A recidiva e a estabilidade da correção do apinhamento ântero-inferior em amostras tratadas com e sem extrações, também foram revistas. Da mesma maneira, foi realizada uma revisão sobre as alterações na forma do arco dentário (largura intercaninos, largura intermolares e comprimento do arco) durante o tratamento, e na pós-contenção.

\section{1 - INDICAÇÃO DE EXTRAÇÕES NA ORTODONTIA}

Celsius, no começo da era cristã, já aconselhava extrair dentes decíduos para facilitar a erupção dos permanentes. Bourdet (1757) recomendava a extração dos pré-molares para aliviar o apinhamento dos dentes anteriores, com um objetivo claramente estético ${ }^{24}$.

John Hunter (1771), em seu livro "História natural dos dentes", descreve a correção da protrusão dos dentes com a extração dos pré-molares. Esta abordagem extracionista foi transmitida a seu discípulo Fox (1803), que defendia a extração de dentes decíduos, como medida preventiva da ocorrência das más posições dentárias com a erupção dos dentes permanentes ${ }^{24,104}$. 
Delabarre, em sua obra "Odontologia” (1815) é contra a extração de dentes decíduos, porque estes servem como mantenedores de espaço e a extração desses dentes poderia afetar o crescimento e desenvolvimento dentário ${ }^{24}$.

Lefoulon (1841), considera que não se deve extrair pré-molares sem antes estimular o crescimento ósseo através da expansão, mesmo quando há apinhamento $^{24}$.

$\mathrm{Na}$ mesma época, o critério extracionista seguia com forte tendência como um "requisito imprescindível na prevenção e correção de certas irregularidades dentárias". Farrer, em sua obra de 1888, alerta que "a extração indiscriminada pode criar problemas e novas dificuldades" ${ }^{, 24,104}$. Maclean (1857) aconselha a extração dos primeiros molares permanentes, para que o resto dos dentes se alinhem melhor ${ }^{24}$.

Nessa linha de pensamento se encontrava também Edward Angle, que na $6^{\mathrm{a}}$ edição do seu livro, considera que é difícil generalizar as indicações das extrações, e esse é um problema que envolve considerações amplas, e merece um estudo mais detalhado de cada caso. Na Classe II, divisão 1, Angle aconselhava que para estabelecer harmonia no tamanho dos arcos dentários e melhorar a oclusão, os primeiros pré-molares superiores deveriam ser extraídos ${ }^{24,104}$.

Anos depois, Angle defende com ardor o conceito de desenvolvimento funcional, no qual apregoa que os dentes devem ser colocados em suas posições corretas e articulados perfeitamente entre si, para que a função estimule o crescimento dos maxilares, e para que haja espaço para todos os dentes. Este posicionamento pôs fim a uma época em que os clínicos haviam recorrido às 
extrações em casos de má posição dentária ou de falta de espaço. Angle levou essa posição ao extremo: "nunca devem-se extrair dentes" 3,4,24,38,104. Para firmar essa idéia, Angle assim definiu "oclusão normal” : "O melhor equilíbrio, a melhor harmonia, as melhores proporções bucais com relação as outras estruturas, requer a existência da dentadura completa e que cada dente ocupe sua posição normal" $\left(\right.$ ANGLE, 1907) ${ }^{3}$.

Os objetivos de Angle para a correção da má oclusão sugerem: (1) uma estética facial e dentária, (2) uma saúde periodontal, (3) funcionamento ideal dos dentes e (4) um resultado estável. Esses objetivos foram traçados no início do ano de 1900 e são válidos até os dias de hoje. Mas, na concepção de Angle, esses objetivos só seriam alcançados se todos os dentes estivessem presentes na cavidade bucal. Entretanto, para $\mathrm{CASE}^{28}, \mathrm{HAHN}^{48}, \mathrm{TWEED}^{127}, \mathrm{BEGG}^{10}, \mathrm{STRANG}^{119}$, LISCHER $^{63}$, e muitos outros afirmaram não ser possível, manter todos os dentes na boca durante o tratamento de alguns tipos de má oclusão.

Apresentando indicações de extrações de dentes em procedimentos ortodônticos, TWEED ${ }^{127}$, em 1944, esclarece que todos os dentes deveriam ser mantidos o mais integralmente possível. No entanto, em seus pacientes já tratados constatou surpreso que, o seu sucesso era menor do que $20 \%$ e seus insucessos maiores do que $80 \%$. Com base nesses resultados, Tweed passou a considerar necessária a extração de dentes, em praticamente todos os casos de prognatismo dento-alveolar, para sua redução e para alinhar os dentes no os so basal ${ }^{78,81,128,130,132}$.

Preocupando-se também com a harmonia das linhas faciais, TWEED $^{127}$, em 1944, concluiu que o equilíbrio e a harmonia da estética facial são 
alcançados quando, os incisivos inferiores são posicionados verticalmente em sua base óssea e portanto, a obtenção de uma "oclusão normal" pela terapia ortodôntica é bastante limitada. Desta maneira, quando ocorre discrepância entre as estruturas óssea e dentária, uma melhor estética facial será obtida com a remoção de dentes.

De fato, os casos de biprotrusão tratados por Tweed que requereriam esse diagnóstico, foram responsáveis por mudar a concepção ortodôntica sobre extração. Entretanto, a filosofia e a técnica de tratamento estabelecida por Tweed está sempre sendo atualizada e refinada ${ }^{60}$.

\section{2 - INDICAÇÕES DE EXTRAÇÕES NA MÁ OCLUSÃO DE CLASSE}

\section{II}

A má oclusão de Classe II é caracterizada por uma relação distal do primeiro molar inferior em relação ao primeiro molar superior ${ }^{3}$. Ela pode ser individualizada em Classe II, divisão 1 que possui como característica principal a sobressaliência, evidenciando na maioria dos casos, um perfil facial acentuadamente convexo, e a Classe II, divisão 2 geralmente acompanhado de uma sobremordida profunda. A má oclusão de Classe II pode ser dentoalveolar, esquelética ou uma combinação das duas. Existem diversos métodos de tratamento para esse tipo de má oclusão, os quais dependem tanto da época de intervenção ortodôntica, quanto do grau de severidade da má oclusão. As indicações do tratamento ortodôntico utilizando o protocolo de extrações serão retratadas a seguir. 


\subsection{1 - Indicações de extrações por biprotrusão}

Contrariando o princípio não extracionista de Angle, $\mathrm{CASE}^{27,28}$, em 1908, admitia as extrações nos casos de protrusões acentuadas ou nas irregularidades dento-faciais severas.

Os principais casos de má oclusão de Classe II, divisão 1 que requerem extração, segundo $\operatorname{CASE}^{27,28}$ são: 1- aqueles que possuem protrusão do lábio superior, com os dentes inferiores e a mandíbula bem posicionados ${ }^{13}$, e $2-$ aqueles casos com protrusão superior acompanhado de retrusão mandibular. Enfatiza ainda que, a extração não deve estar relacionada com apinhamento, e sim com a obtenção de um perfil facial harmônico ${ }^{28}$.

TWEED $^{127}$ em 1936, ao aplicar os princípios básicos da técnica de Arco de Canto, no tratamento das más oclusões de Classe II, divisão 1, sem extração, percebeu que não conseguia bons resultados. Ao final do tratamento esses casos eram transformados meramente em biprotrusões. Esses fracassos não ocorriam devido a uma deficiência no controle da técnica, mais sim a um planejamento incorreto. Para resolver esse impasse, o autor começou a admitir a possibilidade das extrações dos primeiros pré-molares superiores e inferiores, contrariando os rígidos princípios de seu mestre Angle.

Como discípulo de Angle, TWEED ${ }^{127,128}$, ao aplicar os princípios básicos da técnica do Arco de Canto no tratamento das más oclusões de Classe II, divisão 1, sem extração, preocupava-se com os constantes fracassos clínicos obtidos, ao perceber que ao final do tratamento as más posições tornavam-se biprotrusões. Para solucionar esse impasse, TWEED ${ }^{127,128}$, em 1936, passou a admitir a 
possibilidade das extrações dos primeiros pré-molares superiores e inferiores para obter melhor posicionamento dos dentes em suas inclinações axiais corretas, contrariando assim os princípios de seu mestre. Anteriormente, em $1941^{128}$, idealizou o preparo de ancoragem, que sem dúvida, aliado às extrações dentárias, alteram todo o sistema mecânico de ANGLE ${ }^{3,4}$.

Graças à sua genialidade, Tweed revolucionou a Ortodontia, apresentando casos retratados com extrações dos primeiros pré-molares, provando indiscutivelmente a eficiência de sua mecânica, quando coadjuvada por um diagnóstico correto.

O plano de tratamento ortodôntico pode variar de acordo com as características dentárias, esqueléticas e faciais de cada paciente e da mecânica utilizada por cada profissional. Estudos realizados sobre a má oclusão de Classe II, revelam que as extrações dentárias devem constituir parte do tratamento ortodôntico quando essa má oclusão for considerada uma verdadeira biprotrusão ou casos em que se necessita da correção da relação ântero-posterior dos $\operatorname{arcos~dentários~}^{119}$.

Segundo TERRY ${ }^{123}$, em 1969, casos com um maior deslocamento para mesial dos dentes superiores mas com um bom perfil facial, exceto pelo posicionamento anterior do ponto $\mathrm{A}$, podem ser melhor tratados com a remoção bilateral dos pré-molares superiores. Geralmente os dentes escolhidos para serem extraídos são os primeiros pré-molares. Entretanto, as mensurações dos dentes frequentemente indicam que a remoção do segundo pré-molar, por ser este menor que o primeiro, permitirá melhor intercuspidação reduzindo assim o problema de 
espaço ou diminuindo a tendência dos dentes ântero-inferiores sofrerem um leve apinhamento, conseguindo-se, assim, a melhor estética nos incisivos superiores.

Para SHEPARD ${ }^{112}$, a correção de casos com biprotrusão maxilar, frequentemente inclui a extração dos primeiros pré-molares superiores e inferiores.

VADEN $^{130}$, em 1991, salientou que casos de Classe II, divisão 1, que apresentam biprotrusão e apinhamento provavelmente serão tratados com a extração dos quatro primeiros pré-molares.

Em 1995, BISHARA ${ }^{13}$ comparou as características dento-faciais pré-tratamento, de pacientes com má oclusão de Classe II, divisão 1, tratados com ou sem extração. Segundo o autor, algumas dessas características podem ajudar a identificar quais parâmetros influenciam na decisão de se fazer extração ${ }^{88}$. O grupo com os quatro primeiros pré-molares extraídos tinha significativamente maior discrepância dentária em ambos os arcos, e os lábios superior e inferior dos homens, e o lábio inferior das mulheres estavam significativamente mais protruídos. Esse resultado indica que, nesse grupo de pacientes, lábio protruído é uma das razões mais importantes para se optar pela extração.

Os autores STRANG ${ }^{19}$ e BRUSOLA ${ }^{24}$ concordam que o primeiro problema a ser resolvido nos casos de Classe II se refere à seleção dos dentes a serem extraídos, mas diferem quanto ao critério de seleção. A decisão, segundo STRANG ${ }^{119}$, depende dos seguintes fatores: 1. A gravidade da má oclusão: - se o caso de Classe II for uma biprotrusão, se extraem geralmente os primeiros prémolares de ambos os arcos ou os primeiros pré-molares superiores e os segundos prémolares inferiores; - se o caso de Classe II está agravado com um crescimento ósseo 
insuficiente, e os segmentos posteriores ocupam o espaço dos dentes anteriores, está indicada a extração dos primeiros pré-molares de ambos os arcos; 2 . O crescimento dos maxilares: se a mandíbula cresceu o bastante para dar lugar a todos os dentes, mas a maxila apresenta apinhamento e rotações dentárias, pode ser aconselhável extrair os segundos molares superiores e utilizar o amplo espaço adquirido para a movimentação distal de todo o arco superior; 3. Idade do paciente: em pacientes com idade relativamente avançada, nos quais é conveniente encurtar ao máximo a duração do tratamento, e cujos dentes estão bem alinhados, as extrações se limitam aos primeiros pré-molares superiores.

\subsection{2 - Indicações de extrações por apinhamento}

Para autores como TULLEY; CAMPBELL ${ }^{126}$, o apinhamento é uma das principais indicações para extrações no arco inferior em tratamentos de casos de Classe II, divisão 1. Eles afirmam não ser possível, criar espaço com aparelhos para corrigir o apinhamento, sem utilizar de extrações no arco inferior. Se os incisivos inferiores forem protruídos para obter espaço para os pré-molares, eles irão recidivar pela ação contrária do lábio.

A terapêutica selecionada para o tratamento ortodôntico dependerá, entre outros, da época de intervenção. Sendo esta realizada na fase da dentadura mista tardia, a relação de má oclusão de Classe II pode ser completamente corrigida sem a necessidade de extrações ${ }^{7,46}$. Quando o paciente não apresentar mais crescimento e possuir um bom arco inferior, o tratamento deverá ser realizado com extrações dos primeiros pré-molares superiores ${ }^{46}$, ou com a distalização dos dentes 
superiores $^{7}$. Quando houver um grande apinhamento no arco inferior, o tratamento deverá ser realizado com a remoção dos quatro primeiros pré-molares ou, dos primeiros pré-molares superiores e dos segundos pré-molares inferiores ${ }^{7,46}$.

Segundo McDOWELL ${ }^{79}$, em 1970, a extração de pré-molares inferiores permite uma mesialização dos molares inferiores, alcançando assim uma condição de relação cêntrica. A extração de pré-molares inferiores permite também uma distalização dos caninos inferiores, em casos de apinhamento ântero-inferior, evitando a protrusão excessiva desses dentes.

Partindo do princípio de que os maxilares dificilmente podem aumentar de tamanho, a extração está indicada em três casos: 1. Para corrigir o apinhamento: é mais difícil obter espaço no arco inferior que no superior, e a idade do paciente afeta o prognóstico da correção. Pode-se corrigir o apinhamento lançando-se mão de distalizar os molares, expandir o arco ou inclinando e protruir os incisivos. Quando o apinhamento inferior é maior que 5 milímetros, todas as possibilidades conservadoras estão esgotadas e a solução é a extração; 2. Para reduzir a protrusão dento-alveolar, melhorando a estética facial e funcional do paciente; 3. Para relacionar adequadamente os arcos dentários em oclusão normal: em más oclusões de Classe II em que e impossível reduzir a protrusão superior, algumas vezes se recorre à extração superior ${ }^{24}$.

Os resultados atuais indicam que uma importante variável clínica que influencia a decisão pela extração é a presença de apinhamento ${ }^{8,38}$. Além disso, na má oclusão de Classe II, há outros parâmetros que podem ser observados, mas são mais subjetivos e incluem a inclinação dos incisivos, a filosofia de tratamento do 
profissional, os princípios biomecânicos praticados, o potencial de crescimento do paciente e a severidade das discrepâncias dento-faciais vertical, horizontal e ânteroposterior $^{14}$.

\subsection{3 - Indicações de extrações para correção da relação molar}

$\mathrm{VADEN}^{130}$, em 1997, apresenta um caso clínico, em que a paciente apresentava uma má oclusão de Classe II de Angle, com discreto apinhamento e protrusão ântero-inferior. Entretanto, ele alegou a necessidade de ganhar espaço no arco inferior para (1) para corrigir o pequeno apinhamento que estava presente e (2) para corrigir a relação molar de Classe II, por meio da mesialização do primeiro molar inferior. Por essa razão, os segundos pré-molares inferiores foram extraídos. Os primeiros pré-molares superiores foram extraídos para facilitar a retração dos dentes ântero-superiores. Vaden ${ }^{130}$ acreditou que essa combinação de extrações seria necessária para a correção da má oclusão, para a manutenção dos dentes no osso basal e restabelecer a harmonia facial. Para isso foi usado o sistema de força direcional de Tweed-Merrifield.

Para PAQUETTE; BEATTIE; JOHNSTON JÚNIOR. ${ }^{89}$, em 1992, a correção total da relação molar de Classe II em pacientes adultos, ocorre em menor escala quando comparado ao mesmo tipo de correção em pacientes adolescentes. Isso se deve ao fato de que em pacientes adultos não se pode contar com o crescimento mandibular para ir de encontro com o movimento distal dos molares superiores. 
VADEN; HARRIS; BEHRENTS ${ }^{130}$, em 1995, apresentaram dois tratamentos de má oclusão de Classe II, um realizado em adolescente e o outro num paciente adulto. Para a correção desse tipo de má oclusão eles trataram os dois casos com a extração de quatro pré-molares mas, a escolha dos dentes extraídos tiveram razões diferentes. No paciente adolescente foi feita a extração dos quatro primeiros pré-molares, enquanto no paciente adulto optou-se pela extração dos primeiros prémolares superiores e segundos pré-molares inferiores. A extração dos segundos prémolares inferiores no paciente adulto, segundo os autores, foi para facilitar a movimentação para mesial do primeiro molar inferior corrigindo, assim, a má oclusão que no paciente adulto é conseguida exclusivamente por movimentação dentária.

\subsection{4 - Indicações de extrações na má oclusão de Classe II em pacientes com crescimento vertical}

Para YAMAGUCHI ${ }^{137}$, muitos clínicos recomendam extrações de pré-molares em pacientes com altura facial anterior aumentada e um plano mandibular aumentado, mesmo quando as discrepâncias dentárias e esqueléticas são consideradas leves, com a convicção de que o movimento mesial dos molares pode permitir uma rotação anterior da mandíbula ${ }^{137}$.

Para tentar melhorar a estética em pacientes com perfil divergente, ou ao menos não piorá-la, LAMARQUE ${ }^{60}$, em 1995, diz que deve-se evitar trabalhar nesses pacientes com a mecânica de Classe II e o preparo de ancoragem, devido a ausência de controle vertical. Em pacientes com perfil divergente e em fase de 
crescimento, o preparo de ancoragem pode melhorar o crescimento alveolar vertical no arco mandibular. Quando esse fenômeno ocorre, uma compensação no crescimento condilar poderá manter o mesmo valor do ângulo FMA. O plano oclusal também poderá manter-se estável mas, a face do paciente pode parecer alongada como um resultado do tratamento ortodôntico. Quanto maior for a tendência de crescimento vertical do paciente, maior será o crescimento alveolar vertical com o preparo de ancoragem.

Portanto, os pacientes com ângulos de crescimento divergentes que possuem má oclusão de Classe II e que apresentam somente discrepância cefalométrica, podem algumas, vezes ser tratados com a extração dos primeiros prémolares superiores e segundos inferiores. Esse padrão de extração é mais adequado para o movimento mesial dos dentes póstero-inferiores, colocando a oclusão numa relação de Classe I mais rapidamente. Além disso, esse procedimento requer menor preparo de ancoragem ${ }^{60}$. Em alguns pacientes o movimento mesial do primeiro molar inferior não é suficiente para corrigir a relação molar de Classe II, então, o elástico de Classe II com força leve é usado cuidadosamente. Para um paciente com esse problema, algum preparo de ancoragem no segundo molar pode ser requerido. É preciso muito cuidado com a mecânica de tratamento utilizada nesse tipo de paciente $^{60}$.

JANSON, et al. ${ }^{56}$, em 2002, apresentaram dois casos clínicos com o objetivo de discutir a influência do padrão facial na decisão de extrações. Para os autores $^{56}$ a dúvida de qual a abordagem terapêutica a ser escolhida, surge quando o apinhamento ou a protrusão de incisivos é leve ou moderada (casos limítrofes). Neste 
momento do planejamento, o padrão facial é uma característica a ser levada em consideração, sendo segundo os autores mais vantajoso, no que se refere à estética facial, se extrair pré-molares no paciente dolicofacial, e não se extrair no paciente braquifacial. Para JANSON, et al. ${ }^{56}$, as extrações no paciente com padrão facial vertical, favorecem a retração de incisivos e a diminuição da altura facial ânteroinferior, que em conjunto propiciam um selamento labial passivo.

Por meio de uma carta enviada ao editor do AJO-DO, RUBIN ${ }^{103}$ contesta o artigo do ROCKE ${ }^{101}$ publicado em julho de 1991 no AJO-DO, no qual este descreve um tratamento extremamente bem sucedido mas, que levanta importantes questões não respondidas no texto. Comenta que o tratamento ortodôntico da má oclusão de Classe II com ângulo do plano mandibular acentuado, com apinhamento no arco inferior está fadado ao fracasso. As extrações dos quatro primeiros prémolares em tais casos, pode ter um resultado desastroso. Acredita que o sucesso do resultado obtido pelo Dr. Rocke não foi relacionado à sua escolha pelo aparelho de Begg. Ele dependeu de uma quantidade extraordinária de crescimento mandibular que ocorreu durante o tratamento. Quantidade essa que não é geralmente observada nesses casos. Para RUBIN ${ }^{103}$, quando o Dr. Rocke, ou qualquer outro, puder mostrar 20 casos consecutivos de Classe II com ângulo mandibular acentuado, tratados com sucesso por meio de extrações de quatro pré-molares, certamente reconsiderará sua opinião. 


\section{3 - CONTRA-INDICAÇÕES DE EXTRAÇÕES NA MÁ OCLUSÃo DE CLASSE II}

A má oclusão de Classe II, classificada por Angle ${ }^{3}$, consiste no posicionamento distalizado do primeiro molar inferior em relação ao primeiro molar superior. Essa classificação dentária, entretanto, pode apresentar características faciais diferentes para cada paciente e conseqüentemente estabelecer planos de tratamento também diferentes. Baseado nesse fato, a extração de pré-molares não deve ser realizada em alguns pacientes com esse tipo de má oclusão. Para $\mathrm{CASE}^{28}$, esses casos de não extração estariam classificados por uma retrusão dos dentes inferiores em relação à um bom posicionamento mandibular (ângulo mento-labial aumentado) e com os dentes superiores bem posicionados ou levemente vestibularizados.

De acordo com SALZMANN ${ }^{104}$, as extrações dentárias na terapia ortodôntica não devem ser utilizadas para abreviar o tratamento ou para alinhar dentes apinhados mas, como um método auxiliar de tratamento, no qual o arco basal não é grande o suficiente para acomodar todos os dentes normalmente, sem provocar uma protrusão dento-alveolar, ou naqueles em que as forças funcionais terão o potencial de causar uma recidiva. As extrações na terapia ortodôntica não são praticadas com base em porcentagens. Os dados cefalométricos que medem a protrusão dos incisivos inferiores com relação ao plano mandibular ou plano de Frankfort, podem servir como guia mas não são aceitas como critério invariável para a extração. 
$\mathrm{Na}$ mesma época, GRABER ${ }^{47}$, apresenta um caso de Classe II tratado ortodonticamente no qual demonstra que a interpretação cefalométrica não deve ser levada tão a risca. A aparente protrusão dos incisivos inferiores não justifica a extração de dentes nesse caso. O paciente apresentava uma possibilidade de crescimento horizontal da mandíbula e por isso o tratamento foi iniciado na fase de dentadura mista. Em outro caso tratado, também de Classe II, afirma que, em alguns casos o posicionamento mais anterior dos incisivos inferiores pode ser aceito.

Para GRABER ${ }^{47}$, a remoção de quatro pré-molares na má oclusão de Classe II, divisão 1 dificulta o controle da sobremordida, dificulta a eliminação da atividade muscular anormal, e o controle da inclinação axial dos incisivos superiores e inferiores, requer maior quantidade de torque, potencializando a resposta iatrogênica do dente. Portanto, a extração de quatro pré-molares pode não ser a melhor escolha, ou melhor, a extração no arco inferior pode não ser aconselhável. Num estudo com 150 pacientes com má oclusão de Classe II, divisão 1, GRABER ${ }^{47}$ notou que dois terços desse pacientes tinham, essencialmente, os arcos inferiores normais, tanto em relação à forma, quanto em relação à posição dos dentes. $\mathrm{O}$ problema estava na relação espacial do arco inferior com o arco superior (e dentes). Essa notação, segundo o autor, sustenta a impressão que a extração no arco inferior geralmente não se faz necessária.

Uma alternativa para a extração de quatro pré-molares naqueles casos em que provavelmente há uma insuficiência de crescimento ósseo, é remover os dois primeiros pré-molares superiores. Isso permitiria uma redução da protrusão da pré-maxila, a eliminação da sobressaliência excessiva, e possibilitaria o 
estabelecimento da atividade normal da musculatura perioral. Além disso, os movimentos radiculares dos dentes em casos tratados com duas extrações são mais fáceis, quando comparados aos casos de extrações de quatro pré- molares, diminuindo também o tempo de tratamento ${ }^{46,64}$.

Apesar da má oclusão de Classe II, divisão 1 de Angle, em um caso apresentado por ARVYSTAS $^{7}$, em 1985, a extração foi contra-indicada no tratamento pois o paciente em questão apresentava um perfil facial reto, sem nenhum apinhamento superior e com os incisivos superiores levemente retroinclinados.

A extração está contra-indicada em casos de má oclusão de Classe II, divisão 1, segundo ARVYSTAS ${ }^{7}$, quando ainda houver desenvolvimento dentário, crescimento alveolar, crescimento ântero-posterior da maxila e da mandíbula. Uma vez cessado o crescimento, uma opção de tratamento sem extração para esse tipo de má oclusão é a distalização dos dentes superiores.

\subsection{1 - Contra-indicações de extração na má oclusão de Classe II, divisão 2}

ANGLE $^{3,4}$ já advertia que as dificuldades do tratamento aumentariam em decorrência de extrações na Classe II, divisão 2. Os dentes anteriores inferiores deveriam ser colocados em posição vertical normal, e caso houvesse perda do dente permanente, o espaço deveria ser substituído por uma prótese dentária. Caso fosse perda de dente decíduo, o espaço deveria ser mantido, permitindo a erupção do sucessor permanente. Concordando com ANGLE ${ }^{3,4}$, CLEALL; BEGOLE ${ }^{30}$ afirmam que, apesar do segmento ântero-inferior ser 
notavelmente estável, as extrações de pré-molares inferiores na má oclusão de Classe II, divisão 2, continua sendo imprudente porque a oclusão dos incisivos inferiores ocorrerá no terço gengival da face palatina dos incisivos superiores. Nessa situação, o menor movimento dos incisivos inferiores pode converter uma suave má oclusão em uma oclusão traumática, na papila gengival dos dentes superiores. Por essa razão, é melhor aceitar um suave apinhamento ântero-inferior nessa má oclusão, do que criar um excesso de espaço na mandíbula com possibilidades de efeitos desastrosos na estabilidade da oclusão ${ }^{30}$.

A Classe II, divisão 2 é uma má oclusão difícil de ser tratada. A Literatura Britânica enfatiza a necessidade da extração quando no tratamento de más oclusões de Classe II, divisão 2. Essa situação foi confirmada na época da popularidade da técnica de Begg, em que as extrações de pré-molares eram essenciais. Em contraste, a Literatura Americana sugere que a extração na Classe II, divisão 2 deverá ser praticada somente quando há discrepância do arco definida, e não como ajuda para o alinhamento dentário ${ }^{104}$. Essa última abordagem é de particular importância nas más oclusões de Classe II, divisão 2, em que a sobremordida conduz freqüentemente a um trauma . A abertura da mordida é mais efetiva quando todos os pré- molares e molares estão presentes e em contato. Há um risco real de insucesso, se os pré-molares inferiores são extraídos no tratamento com aparelhos removíveis e o tratamento com aparelho fixo pode se tornar mais difícil, se não impossível ${ }^{46}$.

Para CLEALL; BEGOLE ${ }^{30}$, em 1982, pacientes com má oclusão de Classe II, divisão 2 em fase de crescimento, na dentadura mista tardia ou no início da 
dentadura permanente, são melhor tratados se a extração puder ser evitada. Essa opção de tratamento sem extração nos casos de má oclusão de Classe II, divisão 2, deve ser adotada sempre que possível pois, as características mais comumente associadas ao tratamento dessa má oclusão com protocolo de extração são a tendência acentuada de achatamento do perfil facial e aumento da sobremordida, ambas desfavoráveis para esse tipo de paciente ${ }^{64}$.

Para YAMAGUCHI; NANDA ${ }^{137}$ (1991), a extração de pré-molares deve ser evitada em casos de sobremordida profunda e com um ângulo mandibular obtuso, devido à tendência de recidiva da sobremordida, e em razão da força muscular durante a mastigação.

Para ALEXANDER; SINCLAIR; GOATES ${ }^{2}$, em 1986, a extração de pré-molares no arco inferior em pacientes adultos, deveria somente ser indicada depois de uma avaliação muito cuidadosa de todas as outras possíveis alternativas. São inúmeras as más consequiências causadas pela extração de quatro primeiros prémolares no paciente adulto. Em primeiro lugar, é virtualmente impossível corrigir a má oclusão de Classe II com essa padronização de extração. Segundo os autores ${ }^{2}$, isso aumentaria a distância que os dentes teriam que movimentar, conseqüentemente aumentando o desconforto do paciente, o tempo de tratamento, o potencial de reabsorção radicular e a possibilidade de problemas periodontais ${ }^{47,64}$.

Os problemas mecânicos resultantes de extrações inferiores são aumentados quando o paciente possui uma curva de Spee acentuada, tornando extremamente difícil o seu nivelamento. Algumas alternativas poderiam ser viáveis 
para essa situação, como por exemplo, a redução de esmalte dos dentes e expandir os dentes posteriores, ou também protruir os dentes anteriores ${ }^{2}$.

\section{4 - RECIDIVA DA CORREÇÃO DO APINHAMENTO INFERIOR}

\subsection{1 - Amostras tratadas com e sem extrações no arco inferior}

SADOWSKY; SAKOLS ${ }^{105}$, em 1982, estudaram a estabilidade a longo prazo do tratamento ortodôntico e avaliaram em um grupo de 96 pacientes tratados entre as idades de 12 a 35 anos. Os registros das relações dentárias foram executados em modelos de estudo no pré-tratamento, pós-tratamento, e ao final de um período de proservação de no mínimo 12 anos. A amostra foi composta por pacientes Classe I e Classe II, tratados com extrações de quatro pré-molares e sem extrações de pré-molares. Ao final do tratamento, todos os pacientes apresentaram oclusões ideais. Os resultados a longo prazo, quando comparados com a má oclusão original, mostraram um aumento no apinhamento ântero-inferior em $9 \%$ dos casos. Com relação ao apinhamento ântero-inferior, até 3 milímetros de discrepância foi aceito como dentro da normalidade ${ }^{66}$. Enquanto no início do tratamento $35 \%$ da amostra apresentava apinhamento ântero-inferior acima da variação considerada normal, $15 \%$ dos casos apresentou um grau de apinhamento acima de 3 milímetros ao final do tratamento. Os autores ${ }^{105}$ sugerem que, os ortodontistas devem ficar alertas com relação à mudanças a longo prazo nas relações dentárias, muitos anos após o tratamento, e levar isto em conta, quando aconselharem os pacientes sobre os possíveis benefícios do tratamento ortodôntico. 
PAQUETTE; BEATTIE; JOHNSTON JÚNIOR. ${ }^{89}$, em 1992 compararam o comportamento a longo prazo, de duas amostras de pacientes Classe II, divisão 1 tratados com aparelhos de Arco de Canto, sendo que estes sessenta e três pacientes, foram considerados como passíveis igualmente de receber tratamentos com ou sem extrações ("borderline”). Desta forma, 33 casos foram tratados com extração e 30 sem extração de pré-molares, com intervalo médio de acompanhamento pós-contenção de 14,5 anos. As duas alternativas produziram mudanças pós-tratamento idênticas. Os pacientes tratados sem extração tinham um apinhamento inicial de 5,1 milímetros, sofreram uma recidiva para em média para 3,4 milímetros. Por outro lado aqueles pacientes que foram tratados com extração de quatro pré-molares, que ao início do tratamento apresentaram um índice de Little de 6,5 milímetros, sofreram uma recidiva para em média 2,9 milímetros.

ROSSOUW et al $^{102}$, em 1993, realizaram estudo com oitenta e oito pacientes leucodermas, para avaliar a estabilidade de sua dentição após o tratamento ortodônticos com aparelhos de Arco de Canto, sendo que 44\% receberam tratamento sem extrações e $56 \%$ com extrações. As avaliações foram realizadas antes do tratamento, ao final do tratamento e em média 7 anos após o final do tratamento. Não houve diferenças nas mudanças ocorridas quando a amostra foi dividida em pacientes com e sem extração, no período final do tratamento e na pós-contenção. O índice de irregularidade de Little estava dentro de uma variação normal e permaneceu estável durante o período estudado, variando de um valor médio de 4,21 milímetros prétratamento, para 1,71 milímetros no pós-tratamento, indicando estabilidade clínica aceitável dos resultados . 
LUPPANAPORNLARP; JOHNSTON JÚNIOR ${ }^{76}$, em 1993, compararam os resultados a longo prazo (média de 15 anos após o final do tratamento ortodôntico) da terapia ortodôntica com e sem extrações de 62 pacientes portadores de má oclusão de Classe II, sendo 33 tratados com extrações e 29 tratados sem extrações. As mudanças ocorridas no pós-tratamento foram essencialmente as mesmas para os dois grupos, sendo que o padrão de mudança dentária e recidiva, foi correlacionado como uma compensação ao deslocamento sagital mandibular, porém o deslocamento mesial no grupo com extrações foi significativamente maior. O índice de irregularidade no pós-tratamento foi de 2,6 milímetros no grupo tratado com extração e 3,1 milímetros no grupo tratado sem extrações.

BISHARA et $\mathrm{al}^{17}$, em 1994, estudaram pacientes com má oclusão de Classe II, divisão 1, com abordagem sem extrações de pré-molares, e com extrações de quatro primeiros pré-molares, tratados com a técnica do Arco de Canto, sendo que resultado final destes tratamentos foi considerado sucesso. Uma série de parâmetros foram medidos em modelos de gesso, antes do tratamento, póstratamento e pelo menos 2 anos após o final do tratamento. Como resultado observaram $^{17}$ que no pós-tratamento, os dois grupos experimentaram um aumento similar na discrepância entre o tamanho dentário e o comprimento do arco, sendo de 1,3 e 1,25 milímetros, respectivamente para o grupo sem e com extrações.

ARTUN; GAROL; LITTLE 6 , em 1996, avaliaram a estabilidade a longo prazo do alinhamento ântero-inferior, em uma amostra de pacientes Classe II, divisão 1, tratados com sucesso, sendo que a extração de quatro pré-molares foi executada em 37 pacientes da amostra, e 41 pacientes foram tratados sem extrações. 
As avaliações dos registros (modelos e cefalometria) foram executadas no prétratamento, pós-tratamento, e em média 14 anos após a remoção das contenções. Os resultados mostram um aumento da irregularidade dos incisivos, sem diferença para a recidiva do alinhamento ântero-inferior dos casos tratados com ou sem extração de pré-molares, sendo que na amostra tratada sem extrações, a recidiva chegou a 3,36 milímetros, excedendo o apinhamento pré-tratamento que era 2,77 milímetros . A recidiva nos pacientes tratados com extrações chegou em média a 4,05 milímetros, chegando próximo aos valores pré-tratamento de 5,27 milímetros. Os autores ${ }^{6}$ concluem que as chances de se manter o alinhamento dos incisivos é menor do que $50 \%$, apesar dos bons resultados oclusais ao final do tratamento, permitindo interpretar que a recidiva do alinhamento ântero-inferior é inevitável, mesmo com um diagnóstico bem feito e resultados satisfatórios ao final do tratamento. Os autores $^{6}$ sugerem uma contenção semi-permanente no segmento ântero-inferior após a remoção dos aparelhos, porém há necessidade de se estudar consequiências do uso prolongado de contenções coladas.

BISHARA; CUMMINS; ZAHER ${ }^{14}$, em 1997 estudaram pacientes com má oclusão de Classe II, divisão 1, tratados com abordagem sem extrações de pré-molares, e com extrações de quatro primeiros pré-molares, com a técnica do Arco de Canto, sendo que, o resultado final destes tratamentos foi considerado sucesso. Uma série de parâmetros foram medidos em modelos de gesso antes do tratamento, pós-tratamento e pelo menos 2 anos após o final do tratamento. Como resultado observaram ${ }^{14}$ que no pós-tratamento os dois grupos experimentaram um aumento similar na discrepância entre o tamanho dentário e o comprimento do arco, sendo de 1,3 e 1,25 milímetros respectivamente para o grupo sem e com extrações. 
Em 1999, LITTLE $^{73}$, relatou que, por mais de 40 anos, o Departamento de Ortodontia da Universidade de Washington, em Seattle, se concentrou na coleta de mais de 800 conjuntos de exames de pacientes para verificar a estabilidade e a recidiva no tratamento ortodôntico. Todos os pacientes completaram o tratamento há uma década ou mais antes do último conjunto de dados. Segundo o autor ${ }^{73}$, as extrações de pré-molares, a fim de permitir o alinhamento dos dentes apinhados, têm sido um procedimento aceito por décadas e continua sendo o tratamento mais comum utilizado para pacientes com arcos desalinhados. Apesar de se alcançar normas cefalométricas sugeridas e aceitas, e apesar de se aderir aos padrões clínicos usuais de forma do arco, trespasse vertical, etc., a manutenção, a longo prazo, de resultados aceitáveis é desapontadora , com apenas $30 \%$ dos pacientes mostrando resultados aceitáveis a longo prazo. O uso indefinido de contenções fixas ou removíveis, talvez para a vida toda, parece ser o único recurso lógico. Infelizmente, as sequielas indesejáveis de tal programa de contenção não são conhecidas.

\subsection{2 - Amostras tratadas com extrações no arco inferior}

BOESE $^{20,21}$, em 1980 avaliou os resultados clínicos a longo prazo da fibrotomia supracristal e desgaste interproximal em 40 pacientes tratados ortodonticamente com extrações de pré-molares, porém sem o uso de qualquer tipo de dispositivo para contenção. Como resultados reduziu um índice de Little prétratamento médio de 9,18 milímetros, sendo que este, recidivou no pós-tratamento(4 a 9 anos) para apenas de 0,62 milímetros. O autor ${ }^{20,21}$ conclui que a fibrotomia 
associada ao desgaste interproximal, produz estabilidade a longo prazo de dentes previamente girados, que receberam correção ortodôntica, principalmente do segmento ântero-inferior. Estes resultados são melhores que outros trabalhos com extrações $^{72,80}$, em que não foi realizada a fibrotomia .

BEGOLE; SADOWSKI ${ }^{11}$ em 1999, em uma revisão da literatura, concluíram que a estabilidade a longo prazo continuará a ser uma preocupação dos pacientes e dos ortodontistas. Os achados das pesquisas tendem a ser desapontadores, particularmente com respeito à irregularidade dos incisivos inferiores. Entretanto, relatos anedóticos por parte dos clínicos são sempre mais otimistas. Eles representam o sucesso com aderência a um rigoroso protocolo de contenção e ao uso de estratégias para aumentar a estabilidade, incluindo atenção a detalhes na finalização, fibrotomia supracristal ${ }^{20,21,35}$, desgaste interproximal do esmalte ${ }^{109,110,111}$ e contenção fixa a longo prazo ${ }^{106}$. É insensato esperar um resultado perfeitamente estável por toda a vida, dada a maturação da face e da dentição que está se processando.

LITTLE; WALLEN; RIEDEL ${ }^{67}$, em 1981,com a intenção de avaliar possíveis causas da recidiva do alinhamento ântero-anterior e prever resultado pós-contenção a longo prazo, com informação dos modelos pré e pós-tratamento , avaliaram 65 pacientes no estágio de dentadura permanente que foram tratados com extração de quatro pré-molares e mecânica do Arco de Canto, decorridos pelo menos 10 anos da remoção de todos os dispositivos de contenção. Os pacientes apresentavam um apinhamento ântero-inferior (índice de irregularidade de Little) no pré-tratamento com valor médio de 7.31 milímetros, que foi corrigido para 1.73 milímetros ao final do tratamento corretivo, e recidivou para 4.63 milímetros no 
período de 10 anos pós-contenção. Somente $30 \%$ dos pacientes foram considerados com alinhamento ântero-anterior clinicamente aceitáveis. Os autores ${ }^{67}$ consideraram que a longo prazo, o comportamento do alinhamento ântero-anterior é variável e imprevisível, e que nenhuma variável avaliada neste estudo, tais como quantidade de apinhamento inicial, idade, gênero, tipo de má oclusão de Angle, tempo de contenção foram úteis para se estabelecer um prognóstico do resultado a longo prazo.

SHIELDS; LITTLE; CHAPKO ${ }^{113}$, em 1985 avaliaram 54 casos tratados com extração de quatro primeiros pré-molares e técnica do Arco de Canto tradicional, com pelo menos dez anos sem contenção, utilizando-se de modelos e telerradiografias de perfil, buscaram definir parâmetros cefalométricos pré e póstratamento, para predição do comportamento a longo prazo do alinhamento ânteroinferior. Concluíram ${ }^{113}$ não ser possível prever o apinhamento pós-contenção, com base em valores cefalométricos pré e pós-tratamento, porém o grupo com menos apinhamento pós-contenção foi tratado em média, com verticalização do incisivo inferior de $4^{\circ}$, enquanto pacientes que apresentaram apinhamentos mais severos, não apresentaram mudanças, ou sofreram vestibularização dos incisivos inferiores. As mudanças cefalométricas pós-contenção, não explicam o apinhamento póscontenção, e nem a inclinação axial, nem posição de corpo dos incisivos inferiores em qualquer dos períodos estudados, foi associado com irregularidade no alinhamento ântero-inferior na pós-contenção.

LITTLE; RIEDEL; ARTUN ${ }^{72}$, em 1988, avaliaram o alinhamento ântero-inferior de trinta e um pacientes, tratados com extrações de quatro prémolares (mecânica do Arco de Canto), nos períodos pré-tratamento, pós-tratamento , 
e dez e vinte anos pós-contenção, usando para tanto, o índice de irregularidade de Little para os modelos inferiores, nos quatro períodos avaliados. Em 29 dos 31 casos houve retração (verticalização) ou manutenção da inclinação do incisivo inferior em sua base apical durante a mecânica corretiva. A média do índice de irregularidade na região ântero-anterior no pré-tratamento foi de 7,41 milímetros, 1,66 milímetros no pós-tratamento, 5,25 milímetros na avaliação dez anos pós-contenção, e 6,02 milímetros, ao final de vinte anos sem contenção. Os autores ${ }^{71}$ constataram, que o apinhamento continua a aumentar no período entre os 10 anos pós-contenção até 20 anos sem contenção, mas em um menor grau quando comparado com o período que compreende do final da contenção, até 10 anos pós-contenção. Concluem ${ }^{72}$, que após o final do surto de crescimento, as mudanças oclusais se mostram imprevisíveis e variáveis de caso para caso, não havendo como prever a estabilidade quando se avaliam os registros iniciais e os resultados do tratamento. Assim, sugeriu-se o uso de contenção fixa ou removível pelo resto da vida, como único meio de se assegurar um alinhamento satisfatório no pós-tratamento, bem como informar aos pacientes e pais da ocorrência destas mudanças a longo prazo, de forma que entendam as limitações dos profissionais da Ortodontia e o seu papel na manutenção dos resultados do tratamento.

LITTLE; RIEDEL; ENGEST ${ }^{71}$, em 1990 , avaliaram os registros de trinta pacientes que foram submetidos à extração seriada de dentes decíduos, mais quatro primeiros pré-molares, seguido de tratamento ortodôntico e contenção. O índice de Little inicial era de 4,13 milímetros. Os registros diagnósticos foram avaliados nos estágios pré-extrações, início do tratamento ativo, final do tratamento ativo, e no período mínimo de 10 anos após a remoção dos aparelhos de contenção. 
Todos os casos foram tratados com a técnica do Arco de Canto padrão, e foram julgados clinicamente satisfatórios ao final do tratamento ativo. A média do índice irregularidade de Little foi de 4.39 milímetros, na pós contenção. Os autores ${ }^{71}$ concluem, que não há diferença com relação à estabilidade, entre a amostra de extração seriada e a amostra tratada com extrações de pré-molares após sua erupção completa $^{67}$, bem como a irregularidade pós-contenção é uma resposta inevitável em casos com inadequado comprimento de arco pré-tratamento. Mesmos resultados achados por WOODSIDE et al $^{136}$, para o procedimento de extração seriada. Já PETROVIC; STUTZMANN ${ }^{93}$, afirmam que o tratamento precoce proporciona uma melhor estabilidade.

McREYNOLDS; LITTLE ${ }^{80}$, em 1992, avaliaram os modelos dentários e radiografias cefalométricas de 46 pacientes, tratados com extração de segundos pré-molares inferiores e técnica do Arco de Canto convencional, sendo que estas avaliações foram executadas em três períodos distintos: antes do tratamento, ao final do tratamento, e com pelo menos 10 anos após a eliminação dos dispositivos de contenção. A amostra foi dividida em dois grupos, um com extrações precoce dos segundos pré-molares inferiores ( dentadura mista), e outro com extrações tardias dos mesmos dentes (dentadura permanente). Os resultados mostraram não haver diferença na estabilidade a longo prazo para os dois grupos, pois a irregularidade dos incisivos que era de 4 e 5,4 milímetros, respectivamente para o grupo da dentadura mista e permanente, aumentou no período da póscontenção para em média 3,5 e 4 milímetros, seguindo a ordem supracitada. Quando a amostra foi dividida tendo como critério a má oclusão, os pacientes Classe II de Angle apresentaram uma irregularidade na pós-contenção de 4,4 milímetros, ou seja, 
maior do que os 3 milímetros para os pacientes Classe I. As mudanças na inclinação axial dos incisivos durante o tratamento e na pós-contenção e sua relação com o apinhamento inferior foi altamente variável, desta maneira, a condução do tratamento para valores normativos cefalométricos parece não ser um fator que garanta a estabilidade do alinhamento dos incisivos na pós-contenção. Também, não encontraram correlação entre o alinhamento dos incisivos pré-tratamento e póscontenção. Os autores ${ }^{80}$ sugerem que os clínicos devem informar seus pacientes da importância de um longo período de contenção, bem como os pacientes devem entender que tem papel importante na manutenção dos resultados do tratamento a longo prazo.

RIEDEL; LITTLE; BUI ${ }^{100}$, em 1992 , avaliaram os modelos e radiografias cefalométricas de perfil de 42 pacientes em três períodos distintos: antes do tratamento, após o tratamento e 10 anos pós-contenção. Todos os pacientes foram submetidos a tratamento ortodôntico com a técnica do Arco de Canto, com extração de um ou dois incisivos inferiores, para corrigir uma irregularidade de incisivos de 2,38 milímetros. O aumento do índice de irregularidade no pós-contenção foi de 0,33 milímetros a 0,36 milímetros.

DE LA CRUZ et $\mathrm{aP}^{33}$, em 1995 , com o propósito de se estudar a estabilidade das mudanças induzidas pelo tratamento ortodôntico na forma do arco mandibular, estudaram 87 pacientes Classe II e I de Angle tratados ortodonticamente com a extração de quatro pré-molares, acompanhados por um período médio de 15 anos pós-contenção. A amostra de Classe I tinha uma irregularidade de incisivos de 8,1 milímetros ao início do tratamento, foi reduzida a 1,5 milímetros, e recidivou 
para 4 milímetros na pós-contenção. A amostra de Classe II tinha uma irregularidade de incisivos de 4,8 milímetros ao início do tratamento, foi reduzida a 1,4 milímetros, e recidivou para 4,4 milímetros na pós-contenção.

VADEN;HARRIS; GARDNER ${ }^{131}$, em 1997 quantificaram as alterações nas relações dentárias em um série de casos $(\mathrm{n}=36)$ aos 6 anos e novamente 15 anos após o tratamento, tratados com extrações de pré-molares. O tratamento reduziu a irregularidade de incisivos, que era de 4,7 milímetros prétratamento, para valores próximos a zero. A irregularidade recidivou após a fase de contenção, de forma que aqueles contatos que apresentavam mais irregularidade antes do tratamento tenderam a se deslocar mais após o tratamento. Com o tempo a taxa de alteração sofreu um decréscimo, sendo de 1,6 e 2,6 milímetros, respectivamente aos 6 e 15 anos pós-tratamento, justificando a discussão de que a "recidiva", na maioria das vezes, ocorre logo após o tratamento ${ }^{72}$. Houve associações menores, porém estatisticamente significantes entre a recidiva do apinhamento no incisivo e o crescimento sagital dos maxilares. Além disso, os autores ${ }^{131}$ afirmaram que a recidiva, tinha a tendência de ser menor nos casos tratados por um único especialista experiente, do que em amostras de universidades, tratada por diversos residentes em Ortodontia.

\subsection{3 - Amostras tratadas sem extrações no arco inferior}

GLENN; SINCLAIR ; ALEXANDER ${ }^{45}$, em 1987, avaliaram a estabilidade a longo prazo de tratamentos ortodônticos sem extração, através de modelos dentários e registros cefalométricos de 28 pacientes, em média 8 anos após 
a remoção da contenção. Resultados mostraram, que a estabilidade a longo prazo de forma geral é relativamente boa. Os padrões de recidiva vistos $(+1,2$ milímetros $)$ foram similares em natureza, mas de extensão intermediária, entre pacientes normais não tratados ${ }^{114}$ (+0,7 milímetros), e pacientes tratados com a extração de quatro prémolares ${ }^{67}(+2,9$ milímetros $)$. Os autores ${ }^{45}$, notaram que a severidade das mudanças pós-contenção parecer ter alguma relação com a severidade da má oclusão inicial. As más oclusões de Classe II com ângulos ANB maiores e com menores comprimentos mandibulares, mostraram irregularidade de incisivos aumentada na fase de póscontenção, sugerindo que a quantidade e a direção de crescimento facial, pode ser parcialmente responsabilizada pelas mudanças de maturação, vistas no período póscontenção.

LITTLE; RIEDEL ${ }^{68}$, em 1989, avaliaram 30 casos que estavam sem contenção por no mínimo 10 anos, e mostravam espaços generalizados nos dentes anteriores e ausência de apinhamento na região de caninos e pré-molares, antes do tratamento, com índice de Little de 2,5 milímetros ao início do tratamento. Os casos apresentaram na pós-contenção um aumento mínimo para o apinhamento na maioria dos casos, com média de 3,83 milímetros. Os autores afirmam ${ }^{68}$, que o grau de mal alinhamento pós-contenção é imprevisível, assim como para os casos com apinhamento inicial e extrações de pré-molares ${ }^{68,72}$, porém a incidência de apinhamento pós-contenção é menor na amostra com arco inferior espaçado.

LITTLE; RIEDEL; STEIN ${ }^{69}$, em 1990, observaram vinte e seis pacientes com registros obtidos antes do tratamento, após o tratamento, e no mínimo 6 anos sem contenção. Estes pacientes foram tratados com aumento do comprimento 
do arco de pelo menos 1 milímetro durante a dentadura mista (aparelhos fixos, arcos linguais ativos, placa lábio ativa, aparelhos removíveis). O apinhamento dos dentes anteriores na pós-contenção foi de 6,06 milímetros, comparado com 4,63 milímetros no índice de irregularidade nos casos de extração de primeiros pré-molares ${ }^{66}$ e 3,83 milímetros dos casos com espaço generalizado ${ }^{69}$, porém esta comparação intergrupos, segundo os autores ${ }^{69}$, não é válida, pois as amostras são diferentes no que tange ao apinhamento inicial.

HIME; OWENS III ${ }^{51}$, em 1990, avaliaram a estabilidade das expansões de arco obtidas com regulador de função em modelos de gesso. A amostra consistiu de 11 casos tratados com aparelho de Frankel e que estavam em média há 4 anos e 4 meses sem receber nenhum tratamento. Resultados mostraram, de uma forma geral, uma boa estabilidade, com alguma variação individual. A correção da irregularidade de incisivos (com os escudos vestibulares foi em média de -1,25 milímetros) mostrou uma melhor estabilidade (recidiva no índice de $+0,4$ milímetros no período pós-contenção) do que a obtida em outros estudos de estabilidade ${ }^{69,105}$, inclusive quando comparado ao aparelho fixo.

ARTUN; KROGSTAD; LITTLE , em 1990, com o propósito de determinar se os incisivos inferiores poderiam ser acentuadamente vestibularizados, sem que este procedimento aumentasse o potencial para a recidiva do apinhamento inferior, abordaram uma amostra de pacientes adultos com tratamento cirúrgico do prognatismo mandibular, de modo que em 29 pacientes os incisivos inferiores foram vestibularizados mais de $10^{\circ}\left(\mathrm{x}=12.41^{\circ}\right)$ na fase ortodôntica pré-cirúrgica. $\mathrm{O}$ outro grupo de 33 pacientes tiveram apenas pequenas mudanças de inclinação (menor do 
que $2^{\circ}$ ). Um exame de proservação foi executado 10 anos após a cirurgia. Nenhuma diferença entre os grupos nos parâmetros avaliados foi encontrada nos intervalos a longo prazo. A irregularidade dos incisivos (apinhamento secundário ao tratamento ortodôntico é inevitável) aumentou nos dois grupos durante os períodos de proservação (+0,50 milímetros), com os incisivos inferiores verticalizando nos dois grupos durante a observação pós-tratamento. Este estudo demonstra uma associação entre apinhamento pré-tratamento e irregularidade de incisivos a longo prazo. Os autores concluem ${ }^{5}$ que os incisivos inferiores, podem ser vestibularizados durante o alinhamento e nivelamento, nestes casos de adultos com má oclusão de Classe III tratados com combinação ortodontia-cirurgia ortognática, sem aumentar o risco de mal alinhamento no pós-tratamento.

SADOWSKY et $\mathrm{al}^{106}$, em 1994, estudaram uma amostra de 22 casos (predominância de Classe II) tratados ortodonticamente com o fim de se avaliar a estabilidade. Todos os pacientes foram tratados sem extrações com aparelhos fixos técnica Arco de Canto convencional e estavam sem contenções por no mínimo 5 anos. O tempo médio com a contenção inferior fixa, foi de 8.4 anos, sendo que na remoção da contenção, que foi usada pelo menos até os dezoito anos, foi executado um suave desgaste interproximal entre os incisivos inferiores. $O$ índice de irregularidade pré-tratamento foi de 5.2 milímetros no arco inferior; ao final do tratamento foi 1 milímetro, e na pós-contenção foi de 2.4 milímetros. Os autores concluem $^{106}$ que o segmento ântero-inferior, demonstrou um alinhamento relativamente bom a longo prazo, e isto pode ser um reflexo da contenção inferior por tempo prolongado. 
WILLIAMS; ANDERSEN ${ }^{135}$, em 1995, estudaram 42 crianças (23 meninos e 19 meninas) em que os incisivos inferiores tinham sido vestibularizados ou apresentavam movimento de corpo para anterior, como parte do tratamento ortodôntico para corrigir o apinhamento de 4,5 milímetros. Todos os pacientes desta amostra foram selecionados com base no seu padrão de crescimento mandibular, que previa-se através da análise da morfologia mandibular, ser com rotação para anterior, e desta forma esta vestibularização seria estável, segundo os autores ${ }^{135}$, para pacientes com este padrão de crescimento. Os resultados foram baseados em modelos de estudo e análise de cefalogramas de perfil, tomados antes e após o tratamento ativo, bem como após um período de pós-contenção, com um mínimo de 12 anos. Os resultados demonstram que a maioria das mudanças induzidas pelo tratamento se mantiveram bem, mesmo após a remoção das contenções. Houve, no entanto, uma tendência geral de apinhamento mínimo na região de incisivos inferiores (2,8 milímetros).

FREITAS $^{41}$ em 2002, estudou 40 pacientes portadores de má oclusão de Classe I e II de Angle, tratados sem extrações no arco inferior, com o objetivo de avaliar a recidiva do apinhamento ântero-inferior passados 5 anos do término do tratamento, e quais fatores poderiam estar associados coma esta recidiva. Como resultados, encontrou-se que a recidiva do apinhamento ântero-inferior ocorreu na maioria dos pacientes, porém a porcentagem média desta recidiva foi relativamente pequena $(26,54 \%)$. O gênero masculino apresentou, em média, maior apinhamento nas fases inicial e pós-contenção do que o gênero feminino. O grupo com apinhamento inicial suave apresentou maior recidiva que o grupo com apinhamento inicial severo, com valores estatisticamente significantes, portanto, a 
autora conclui que o grau de apinhamento inicial influenciou e se mostrou associado à recidiva do apinhamento ântero-inferior. $\mathrm{O}$ grupo com maiores tempos de contenção apresentou menor recidiva, porém, não significante estatisticamente. Com relação aos demais fatores estudados, aumento das distâncias intercaninos e intermolares, aumento do comprimento do arco, realização de extrações no aco superior, realização de desgastes interproximais, aumento da protrusão dos incisivos inferiores devido ao tratamento, posição final dos incisivos inferiores e tempo de tratamento, nenhum deles se mostrou significantemente associado à recidiva do apinha mento ântero-inferior.

\subsection{4 - Apinhamento ântero-inferior e o desenvolvimento da oclusão}

SINCLAIR; LITTLE ${ }^{115}$, em 1983, avaliaram os modelos dentários de 65 pacientes que apresentavam oclusões normais não tratadas, a fim de descrever a natureza e extensão das mudanças vistas durante o desenvolvimento da oclusão da dentadura mista até dentição permanente nos adultos. O índice de irregularidade de Little se manteve estável da dentadura mista (9-10 anos), até a dentição permanente jovem ( 12-13 anos), e aumentou em média 0,70 milímetros do início da dentição permanente até a fase de adulto jovem (19-20 anos). As mulheres mostraram aumentos no apinhamento mais severos do que os homens. Para o apinhamento inferior a velocidade do aumento do apinhamento, é duas vezes maior na póscontenção da amostra tratada(Little, 1981) ${ }^{67}$ do que o grupo com oclusão normal não $\operatorname{tratada}^{115}$. 
BISHARA $^{16}$, em 1989, avaliaram as alterações nos incisivos entre os 13 e os 28 anos de idade em pacientes com oclusão normal, e reavaliaram os mesmos indivíduos aos 45 anos de idade ${ }^{18,19}$. Seus achados indicaram que houve um aumento da discrepância entre o tamanho dentário e o comprimento do arco. As alterações médias foram de 2,7 milímetros nos homens e de 3,5 milímetros nas mulheres. Essas alterações no alinhamento dos dentes consistem primariamente no resultado de uma diminuição no comprimento disponível do arco. Essas alterações não foram significantemente relacionadas a qualquer variável dentária ou facial, ou seja, os autores afirmam que a causa é multifatorial e está associada com alterações na altura facial, trespasse vertical, inclinação incisal, dimensões do arco e diâmetro mésio-distal de vários dentes ${ }^{18}$.

\section{5 - DIMENSÕES DO ARCO INFERIOR (LARGURA E COMPRIMENTO)}

\subsection{1 - Amostras tratadas com e sem extrações no arco inferior}

GARDNER; CHACONAS ${ }^{42}$, em 1976, com o propósito de responder algumas questões relacionadas a estabilidade dos dentes no arco inferior, após o tratamento ortodôntico, observaram 103 casos, sendo 74 casos tratados sem extração, e 29 casos tratados com extração de 4 primeiros pré-molares. Executaram medidas da largura intercaninos, pré-molares e molares, e do comprimento de arco inferior, para identificar as mudanças ocorridas durante o tratamento e em média 5,2 anos pós-contenção. Como resultados, obtiveram que, nos casos com e sem 
extração, a distância intercaninos apresentou uma recidiva pós-tratamento semelhante nos dois grupos, de forma que algum aumento da largura intercaninos conseguida com o tratamento foi mantida. Obviamente, a distância intermolares apresentou um aumento de 2,04 milímetros no grupo sem extração, e reduziu-se durante o tratamento em média 1,46 milímetros, no grupo com extrações. O comportamento pós-tratamento desta variável foi semelhante nos dois grupos, com reduções mínimas, de forma que esta falta de mudança na pós-contenção, também notada nos casos sem extração, levou os autores ${ }^{42}$ a concluir que uma vez os molares inferiores posicionados, estes dentes mantém a sua largura intermolar. Com relação ao comprimento de arco, este apresentou uma redução de 1,20 milímetros no grupo sem extração, e reduziu-se durante o tratamento em média 6,45 milímetros, no grupo com extrações. O comportamento pós-tratamento desta variável foi semelhante nos dois grupos(-0,99 e -0,86 milímetros respectivamente para os grupos sem e com extrações). A expansão dos caninos tem uma forte tendência a retornar a sua posição original, independente do tipo de tratamento. Sendo assim, o melhor guia para a largura intercaninos é a largura intercaninos original, pré-tratamento ${ }^{108}$. No entanto WALTER $^{133}$, encontrou em casos sem extração, um aumento da largura intercaninos de 2 milímetros, o qual afirmou ter sido mantido na pós-contenção, bem como, uma expansão mantida de 1,4 milímetros na distância intermolares. STRANG ${ }^{119}$ afirmava que a distância intercaninos original não poderia ser violada, mas admitiu, em casos com extrações que a largura poderia ser aumentada se os caninos fossem movidos para porções mais largas do arco. Para a largura intermolares, em casos com extrações, a mudança ocorrida na pós-contenção foi próxima de zero ${ }^{42}$. Nos casos sem extrações, é aparente que a largura intermolares pode ser definitivamente 
expandida, e após a mudança inicial ou a mudança induzida pelo tratamento, o molar permanece onde ele está, independente do tipo de tratamento ${ }^{42}$. WALTER ${ }^{133}$ observou um aumento médio de 1,8 milímetros na largura intermolares, que se mantém por si próprio.

BEGOLE; FOX; SADOWSKY ${ }^{12}$, em 1998, realizaram um estudo sobre as formas dos arcos. Os achados sugerem que a estabilidade pode não estar relacionada com a quantidade de alteração produzida durante o tratamento. Significante expansão pode ser conseguida nas regiões dos pré-molares, podendo-se esperar a sua estabilidade. O maior ganho na largura do arco foi para os segundos pré-molares; em seguida veio o dos primeiros pré-molares, molares e, então, o dos caninos. As distâncias intercaninos para ambos os arcos diminuíram em relação aos valores pré-tratamento. Essa estabilidade na região de pré-molares já havia sido evidenciada por GARDNER; CHACONAS ${ }^{42}$.

BURKE et $\mathrm{al}^{25}$, pelo processo da metanálise de 26 artigos publicados e de algumas dissertações de Mestrado, avaliaram as alterações na largura intercaninos inferior, após o período de contenção. A amostra combinada compreendeu 1.233 indivíduos. Como conclusões, observaram que: 1) a largura intercaninos tende a expandir-se, durante o tratamento, entre 0,8 e 2,0 milímetros, independentemente da classificação da má oclusão e do tratamento ter sido realizado com ou sem extrações; 2) a largura intercaninos tende a diminuir, após o período de contenção, entre 1,2 e 1,9 milímetros, independentemente da classificação da má oclusão e do tratamento ter sido realizado com ou sem extrações; 3) a largura intercaninos tende a mostrar uma alteração “liquida' no período do pós-contenção na 
ordem de 0,5 milímetros de expansão a 0,6 milímetros de constrição, independentemente da má oclusão e do tratamento ter sido realizado com ou sem extrações; 4) desde que a alteração 'liquida' na largura intercaninos foi achada como sendo de aproximadamente zero, esse estudo claramente participa do conceito da manutenção da largura intercaninos original no tratamento ortodôntico ${ }^{119}$.

FASTLICHT $^{37}$, em 1970, afirmou que apinhamento pós-contenção resulta de uma combinação vários fatores, dentre estes, a diminuição da distância intercaninos, de modo que quanto maior a sua redução, maior o apinhamento gerado.

PAQUETTE; BEATTIE; JOHNSTON ${ }^{89}$, em 1992 compararam os efeitos a longo prazo de duas amostras de pacientes Classe II, divisão 1, tratados com aparelhos de Arco de Canto, sendo que 33 casos foram tratados com extração e 30 sem extração. O intervalo médio pós-contenção foi de 14.5 anos. As duas alternativas de tratamento produziram mudanças idênticas pós-tratamento. Houve uma pequena expansão dos caninos durante o tratamento, inclusive para o grupo sem extrações (1,1 milímetros), e na pós-contenção ocorreu uma redução de 0,6 milímetros e 1,2 milímetros, respectivamente para o grupo sem e com extrações. A distância intermolar inferior, foi reduzida 0,6 milímetros no grupo tratado com extrações e aumentada 1,8 milímetros no grupo sem extrações. Esta dimensão permaneceu a mesma, durante o período de controle pós-tratamento, no grupo com extrações e se expandiu 0,7 milímetros no grupo sem extrações. O comprimento de arco foi aumentado 2,9 milímetros no grupo sem extrações e diminuído 9,1 milímetros no grupo de extrações. Na pós-contenção o grupo sem extrações mostrou uma 
constrição de 3,9 milímetros e o grupo com extrações teve uma constrição de 2,6 milímetros, para o comprimento de arco.

\section{LUPPANAPORNLARP; JOHNSTON JÚNIOR ${ }^{76}$, em 1993,} compararam os resultados a longo prazo(média de 15 anos após o final do tratamento ortodôntico) da terapia ortodôntica com e sem extrações, de 62 pacientes portadores de má oclusão de Classe II, sendo 33 tratados com extrações, e 29 tratados sem extrações. As mudanças ocorridas no pós-tratamento, foram essencialmente as mesmas para os dois grupos, sendo que ocorreram reduções no comprimento do arco ( de 2,5 milímetros para o grupo com extrações e de 4,3 milímetros para o grupo sem extrações), na largura intercaninos ( de 1,4 milímetros para o grupo com extrações e sem extrações). A largura intermolares sofreu um aumento no período póscontenção( de 0,5 milímetros para o grupo com extrações e sem extrações).

Para ROSSOUW et $\mathrm{al}^{102}$, em 1993, não houve , durante o tratamento grandes alterações na distância intercaninos inferior (inclusive com pequena redução média de 0,8 milímetros), porém esta medida se alterou na avaliação pós-contenção (redução média de 0,22 milímetros), embora não significativamente, no sentido da diminuição de seus valores para números inferiores aos seus valores originais. O comprimento do arco diminuiu de forma significativa durante todo o período avaliado e foi, segundo os autores ${ }^{102}$, a única variável capaz de influenciar o índice de irregularidade dos incisivos inferiores. As reduções do comprimento do arco variaram de 3,37 milímetros ao final do tratamento, para 1,70 milímetros na pós-contenção. Estas reduções no comprimento de arco são resultado de uma verticalização do incisivo inferior em média de $1,72^{\circ}$, no período de pós- 
contenção, sendo considerada como principal agente etiológico da recidiva dos incisivos inferiores após o tratamento.

BISHARA et al $^{17}$, compararam mudanças pós-tratamento nos arcos dentários de pacientes com má oclusão de Classe II, divisão 1, tratada metade ( $\mathrm{N}=46 ; 20$ homens e 26 mulheres) com abordagem sem extrações, e a outra metade ( $N=45 ; 21$ homens e 24 mulheres) foi tratada com extração de quatro primeiros prémolares, com aparelhos Arco de Canto, e o resultado final destes tratamentos foi considerado sucesso. As dimensões do arco inferior foram medidas antes do tratamento, pós-tratamento e pelo menos 2 anos após o final do tratamento. Os resultado indicam que no pós-tratamento os dois grupos experimentaram uma redução no comprimento do arco. As extrações não alteram significativamente a direção das tendências gerais pós-tratamento de alguns parâmetros, por exemplo: largura intercaninos. Houve um aumento na distância intercaninos durante o tratamento para os grupos com e sem extração, com diminuição no pós-tratamento de 0,7 milímetros para o grupo com extrações, e 1,5 milímetros para o grupo sem extrações. Por outro lado, as tendências de alterações pós-tratamento de outros parâmetros como a distância intermolar, foram significativamente diferentes para o grupo com e sem extrações, havendo uma diminuição da distância intermolar no grupo das extrações de 0,7 milímetros, enquanto esta dimensão aumentou 0,9 milímetros no grupo sem extração, quando se avaliou o mesmo período.

FIDLER et $\mathrm{al}^{41}$, em 1995, avaliaram a estabilidade a longo prazo do alinhamento ântero-inferior em uma amostra de pacientes Classe II, divisão 1, tratados com sucesso (com ou sem extrações) no que se refere aos resultados oclusais 
ao final do tratamento ativo. O tempo de acompanhamento pós-contenção foi de 14 anos. Os resultados mostram uma redução da largura intercaninos (sem extrações:1,33 milímetros; com extrações: 1,75 milímetros), e comprimento do arco (sem extrações:1,21 milímetros; com extrações: 0,77 milímetros) no período póscontenção. A largura intermolares se alterou mais no grupo com extrações, quando consideroutse o período pós-contenção(sem extrações:0,13 milímetros; com extrações: 0,84 milímetros).

ARTUN; GAROL; LITTLE ${ }^{6}$, em 1996, avaliaram a estabilidade a longo prazo do alinhamento ântero-inferior em uma amostra de pacientes Classe II, divisão 1, tratados com sucesso, sendo que a extração de quatro pré-molares foi executada em 37 pacientes da amostra e 41 pacientes foram tratados sem extrações. As avaliações dos registros foram executadas no pré-tratamento, pós-tratamento, e em média 14 anos após a remoção das contenções. Os resultados mostram uma redução da largura intercaninos (sem extrações:1,33 milímetros; com extrações: 1,75 milímetros), e comprimento do arco (sem extrações:1,21 milímetros; com extrações: 0,77 milímetros) no período pós-contenção. A largura intermolares se alterou mais no grupo com extrações, quando se considera o período póscontenção(sem extrações:0,13 milímetros; com extrações: 0,84 milímetros).

\subsection{2 - Amostras tratadas com extrações no arco inferior}

SONDHI; CLEALL; BEGOLE ${ }^{116}$, em 1980, estudaram terradiografias de perfil e modelos de estudo de 53 pacientes(todas as Classes de Angle), para avaliar as interações entre mudanças dimensionais dos arcos dentários 
induzidas pelo tratamento com aparelhos da técnica do Arco de Canto completos, e a estabilidade pós-contenção destas mudanças (período de no mínimo 2 anos póscontenção). O movimento distal dos caninos não assegurou um aumento estável das largura intercaninos, que se reduziu 3,52 milímetros na pós-contenção, discordando de STRANG $^{119}$. Os autores ${ }^{116}$, não encontraram correlação entre as mudanças no comprimento do arco e mudanças de inclinação dos incisivos.

BOESE $^{20,21}$, em 1980, avaliou os resultados clínicos a longo prazo da fibrotomia supracristal e desgaste interproximal em 40 pacientes tratados ortodonticamente com extrações de pré-molares arcos inferiores, porém sem o uso de qualquer tipo de dispositivo para contenção. $\mathrm{O}$ autor ${ }^{20,21}$, concluiu que a largura intercaninos foi aumentada 0,85 milímetros durante o tratamento, e reduziu-se 1,27 milímetros ao final do tratamento, ou seja, 0,42 milímetros menor do que o valor inicial.

LITTLE; WALLEN; RIEDEL ${ }^{67}$, em 1981, avaliando 65 pacientes tratados com extração de quatro pré-molares, com um período de dez anos póscontenção, notaram que tipicamente a distância intercaninos diminuiu em média 2 milímetros após dez anos pós-contenção, com conseqüente aumento do apinhamento, sendo que isto ocorreu independente se o tratamento foi executado com expansão, constrição ou manutenção da distância intercaninos inicial. Os autores $^{67}$ afirmam não haver relação de causa e efeito, entre a mudanças de largura dos $\operatorname{arcos}$ e subsequente apinhamento de incisivos, bem como, a manutenção da distância intercaninos original não é uma garantia de estabilidade. Houve uma correlação fraca entre o grau de redução do comprimento do arco pós-contenção e a 
severidade do apinhamento pós-contenção, pois esta dimensão reduziu-se em média mais de 2 milímetros no período avaliado, sendo que apenas $27 \%$ do apinhamento foi explicado por esta diminuição no comprimento do arco.

LITTLE; RIEDEL; ARTUN ${ }^{72}$, em 1988, observaram que as mudanças oclusais, dentre elas a constrição do arco inferior (largura e comprimento) , são mais intensas na primeira década pós-contenção, porém continuam nos períodos de 10 a 20 anos pós-contenção, portanto após o final do surto de crescimento. Estas mudanças se mostram imprevisíveis e variáveis de caso para caso, não havendo como garantir a estabilidade, quando se avaliam os registros iniciais e os resultados do tratamento.

LITTLE; RIEDEL; ENGEST ${ }^{71}$, em 1990, avaliaram os registros de trinta pacientes que foram submetidos à extração seriada de dentes decíduos, mais quatro primeiros pré- molares, seguido de tratamento ortodôntico e contenção. Todos os casos eram portadores de má oclusão de Classe I ou Classe II de Angle, e o último período avaliado foi no mínimo de 10 anos após a remoção dos aparelhos de contenção. A largura intercaninos e o comprimento do arco diminuiu em 29 dos 30 casos no período de pós-contenção. Não houve diferença entre a amostra de extração seriada $^{71}$, e a amostra tratada com extrações de pré-molares após sua erupção completa $^{67}$.

McREYNOLDS; LITTLE ${ }^{80}$, em 1992 avaliaram 46 pacientes, tratados com extração de segundos pré-molares inferiores e aparelhos de Arco de Canto convencional, com pelo menos 10 anos após a eliminação dos aparelhos de contenção. O comprimento de arco diminuiu na pós-contenção, em média 2,7 
milímetros. A distância intercaninos apresentou aumento durante o tratamento, que foi seguida de diminuição na pós-contenção(-1.8 milímetros) para níveis menores do que os valores originais desta largura. Esta diminuição da distância intercaninos não foi associada com o aumento da irregularidade nos incisivos. Houve diminuição da distância intermolar no período de pós-contenção em média de 0,8 milímetros. Estes resultados, segundo os autores ${ }^{80}$, geram as seguintes implicações clínicas: contenção permanente ou longo período em casos tratados com expansão da largura intercaninos, já que esta medida mostra diminuição no período pós-contenção para valores menores do que no pré-tratamento.

DE LA CRUZ et $\mathrm{al}^{33}$, em 1995, com o propósito de se estudar a estabilidade das mudanças induzidas pelo tratamento ortodôntico na forma do arco mandibular, estudaram 87 pacientes Classe II e I de Angle tratados ortodonticamente com a extração de quatro pré-molares e acompanhados por um período médio de 15 anos pós-contenção. Os resultados mostram que o arco durante o tratamento foi levado a ter uma forma mais arredondada, seguido de uma forma mais estreitada na pós-contenção, sendo que a forma do arco tendeu a recidivar para a forma de prétratamento. Em valores numéricos temos: A largura intercaninos na amostra de Classe I, aumentou 1,4 milímetros durante o tratamento, e diminuiu 1,6 milímetros na pós contenção. A largura intermolares na amostra de Classe I, diminuiu 0,6 milímetros durante o tratamento, e diminuiu 1,2 milímetros na pós contenção. O comprimento do arco na amostra de Classe I, diminuiu 8,6 milímetros durante o tratamento, e diminuiu 2,4 milímetros na pós-contenção. A largura intercaninos na amostra de Classe II, aumentou 0,9 milímetros durante o tratamento, e diminuiu 2 milímetros na pós- contenção. A largura intermolares na amostra de Classe II, 
diminuiu 1,3 milímetros durante o tratamento, e diminuiu 1,0 milímetros na pós contenção. O comprimento do arco na amostra de Classe II, diminuiu 10,4 milímetros durante o tratamento, e diminuiu 2,3 milímetros na pós contenção. Estas mudanças estão de acordo com os trabalhos de LITTLE et al ${ }^{67}$, no qual, há uma diminuição pós-contenção da largura e do comprimento do arco, independente se a largura intercaninos original foi mantida ou aumentada durante o tratamento. Os autores concluem que quanto maior a mudança induzida pelo tratamento, maior a tendência para mudanças pós-tratamento. A forma do arco pré-tratamento parece ser o melhor guia para a estabilidade futura da forma do arco, mas a redução das mudanças induzidas pelo tratamento, não é garantia de estabilidade pós-contenção.

FREITAS; HENRIQUES; PINZAN ${ }^{40}$, em 1996, realizaram um estudo em modelos, objetivando avaliar se havia uma correlação da recidiva do apinhamento ântero-inferior, com as distâncias intercaninos, intermolar e comprimento do arco. A amostra consistiu dos modelos inferiores de 33 pacientes, com má oclusões de Classe I e Classe II, tratados ortodonticamente pela técnica do Arco de Canto Simplificada, com extrações dos primeiros pré-molares superiores e inferiores. Os modelos foram realizados no início, final, 5 e 10 anos pós-contenção. A amostra foi dividida em 2 grupos: o grupo 1, formado por 21 pacientes com uma recidiva mínima do apinhamento inferior, e o grupo 2, formado por 12 pacientes que apresentavam uma recidiva severa. $\mathrm{Na}$ análise comparativa dos modelos para ambos os grupos, os resultados evidenciaram que a distâncias intercaninos foi aumentada de forma semelhante durante o tratamento para os dois grupos (por volta de 1 milímetros), e reduziu-se na pós-contenção de maneira similar nos dois grupos , sendo que a maior redução ocorre nos primeiros cinco anos (0,80 a 1 milímetros), 
quando comparado com o período de 10 anos pós-contenção(0,5 a 0,6 milímetros). A distância intermolares diminuiu durante o tratamento para os dois grupos (de 1,6 a 2,8 milímetros), e reduziu-se pouco na pós-contenção, de maneira similar nos dois grupos. O comprimento do arco, diminuiu durante o tratamento para os dois grupos, e reduziu-se na pós-contenção de maneira similar nos dois grupos, sendo que a maior redução ocorre nos primeiros cinco anos (1,46 a 1,89 milímetros), quando comparado com o período de 10 anos pós-contenção(1 milímetros). Os autores ${ }^{40}$,concluem que as alterações pós-tratamento do comprimento e da largura dos arcos, não foram os fatores responsáveis pela maior recidiva observada no grupo 2, pois os resultados apresentaram-se estatisticamente não significantes.

VADEN; HARRIS; GARDNER ${ }^{131}$, em 1997, quantificaram as alterações nas relações dentárias em um série de casos $(n=36)$, aos 6 anos e novamente 15 anos após o tratamento, tratados com extrações de quatro pré- molares. A largura intercaninos expandida 2,6 milímetros no arco inferior, e após o tratamento metade desta expansão conseguida foi perdida. Este estreitamento na largura intercaninos inferior, poderia ser resultado de um deslocamento mesial dos caninos em função da maturação da oclusão ${ }^{74}$. A largura intermolar decresce significativamente durante o tratamento. Decréscimos mínimos na primeira $(0,46$ milímetros) e segunda reavaliações (0,49 milímetros). O comprimento do arco inferior sofreu uma redução de 5 milímetros durante o tratamento. Continua a decrescer nas reavaliações após o final do tratamento ativo $(0,78$ e 1,21 milímetros, respectivamente aos 6 e aos 15 anos pós-tratamento). 


\subsection{3 - Amostras tratadas sem extrações no arco inferior}

GLENN; SINCLAIR; ALEXANDER ${ }^{45}$, em 1987, observando uma amostra tratada sem extrações, com um período médio de 8 anos pós-contenção, notaram diminuições significativas no comprimento do $\operatorname{arco}(-2,4$ milímetros $)$ e na largura intercaninos(- 1 milímetro), de modo que $95 \%$ dos casos em que a distância intercaninos foi aumentada durante o tratamento, apresentaram diminuição no período pós-contenção, apesar de alterações mínimas do ponto de vista estatístico durante o tratamento. A largura intermolar mostrou considerável estabilidade a longo prazo, sendo aumentada 0,9 milímetros durante o tratamento, e diminuindo 0,5 milímetros na pós-contenção. As más oclusões de Classe II com ângulos ANB maiores e com menores comprimentos mandibulares mostraram, comprimento de arco diminuídos na fase de pós-contenção, sugerindo que a quantidade e a direção de crescimento facial, pode ser parcialmente responsabilizada pelas mudanças de maturação vistas no período pós-contenção.

SANDSTROM; KLAPPER; PAPACONSTANTINOU ${ }^{107}$, em 1988, estudaram o efeito da expansão maxilar, nas larguras intercaninos e intermolares durante o tratamento, e sua estabilidade após a contenção (amostra de pacientes tratados pelo Dr. Haas). A amostra consistiu de 17 casos para o estudo da distância intercaninos (média etária: 14 anos), e 22 casos sem extração para o estudo da distância intermolar (média etária: 12,6 anos). O último período avaliado foi pelo menos 2 anos pós-contenção (as contenções fixas no arco inferior foram mantidas por um período médio de 5,6 anos). A expansão da distância intercaninos foi de 2,2 milímetros durante o tratamento, e houve uma recidiva de menos 1 milímetro na pós- 
contenção (significante estatisticamente, $48 \%$ da expansão obtida foi perdida). E largura intermolar foi expandida 3,3 milímetros durante o tratamento e recidivou 0,5 milímetros na pós-contenção (recidiva não significante estatisticamente).

LITTLE; RIEDEL ${ }^{68}$, em 1989, avaliaram de 30 casos que estavam sem contenção por no mínimo 10 anos, e mostravam espaços generalizados nos dentes anteriores e ausência de apinhamento na região de caninos e pré-molares, antes do tratamento. Nesta amostra, constatourse uma redução consistente no comprimento de arco e largura intercaninos na idade adulta. A constrição da distância intercaninos ocorreu tipicamente, enquanto o comprimento do arco diminuiu em todos os casos, sendo estas diminuições foram progressivas. Para os autores $^{68}$, o grau de constrição das dimensões do arco é imprevisível, e o fato dos espaços no arco inferior não reabrirem em nenhum caso, ilustra a tendência de constrição da amostra.

No mesmo ano, LITTLE; RIEDEL, STEIN ${ }^{69}$, estudaram vinte e seis pacientes com registros obtidos antes do tratamento, após o tratamento, e no mínimo 6 anos sem contenção, sendo que estes foram tratados com aumento do comprimento do arco de pelo menos 1 milímetro durante a dentadura mista (aparelhos fixos, arcos linguais ativos, PLA, aparelhos removíveis). Todos os pacientes mostraram perda do aumento do comprimento do arco obtido durante o tratamento, com somente 6 dos 26 pacientes, mostrando algum ganho além das dimensões pré-tratamento. A diminuição em largura foi um achado constante após a contenção. A constrição pós-contenção do comprimento do arco mandibular e da largura do arco, em casos de alargamento do arco ou desenvolvimento do arco na 
dentadura mista, é mais forte e com uma tendência de recidiva clinicamente significante, do que os outros métodos de tratamento (extração de primeiros prémolares $^{67}$ e casos com espaço generalizado ${ }^{68}$ ). A recidiva no comprimento do arco se deve ao movimento mesial do molar e a inclinação lingual dos incisivos, confirmada nos achados cefalométricos ${ }^{113}$.

HIME; OWENS III ${ }^{51}$, em 1990, avaliaram a estabilidade das expansões do arco, obtidas com regulador de função (R.F.). As mudanças induzidas pelo tratamento e no período pós-contenção foram avaliadas para as larguras do arco, comprimento do arco e irregularidade de incisivos. A amostra consistiu de 11 casos tratados com aparelho de Frankel e que estava em média 4 anos e 4 meses sem receber nenhum tratamento. Resultados mostraram, de uma forma geral, uma boa estabilidade, com alguma variação individual. A largura intercaninos (aumento de 1.5 milímetros durante o tratamento; recidiva pós-contenção -0.30 milímetros), e a largura intermolar(aumento de 1,35 milímetros durante o tratamento; houve um aumento na pós-contenção $+0,25$ milímetros) mantiveram o aumento obtido durante o tratamento. A diminuição do comprimento $(-0,65$ milímetros $)$ do arco com o tratamento, continuou a ocorrer no período pós-contenção (-0,80 milímetros), embora em menor grau do que outros estudos ${ }^{45,69}$. Os resultados embasam as afirmações de Frankel com relação à estabilidade deste tipo de expansão.

SADOWSKY et $\mathrm{al}^{106}$, em 1994, estudando uma amostra de pacientes tratados sem extrações com aparelhos fixos Arco de Canto convencional, e que estavam sem contenções por no mínimo 5 anos. O tempo médio de utilização da contenção inferior fixa foi de 8.4 anos, sendo que na remoção da contenção que foi 
usada pelo menos até os dezoito anos, foi executado um leve desgaste interproximal entre os incisivos inferiores. A solução do apinhamento dos incisivos inferiores foi obtida sem avanço dos incisivos ou movimento distal do molar inferior (não houve aumento do comprimento do arco), no entanto, ambos os arcos foram expandidos transversalmente. Durante o período pós-tratamento (contenção e pós- contenção), todas as variáveis mostraram recidiva (comprimento do arco: -1 milímetro; e largura do arco inferior: caninos perderam $50 \%$ da expansão obtida durante o tratamento e os molares 34\%), embora a contenção inferior tenha sido utilizada por tempo prolongado.

WILIAMS; ANDERSEN ${ }^{135}$, em 1995, estudaram 42 crianças (23 meninos e 19 meninas) em que os incisivos inferiores tinham sido vestibularizados, ou apresentavam movimento de corpo para anterior, como parte do tratamento ortodôntico. Todos os pacientes desta amostra foram selecionados com base no seu padrão de crescimento mandibular, que previa-se através da análise da morfologia mandibular que era com rotação para anterior, e desta forma esta vestibularização seria estável nestes pacientes com este padrão de crescimento. O período de acompanhamento pós-contenção foi de no mínimo de 12 anos. Os resultados demonstram uma aceitabilidade clínica dos princípios empregados, sendo que na maioria das mudanças induzidas pelo tratamento se mantiveram bem, mesmo após a remoção das contenções. Houve, no entanto, uma tendência geral de redução da distância intercaninos (0,8 milímetros), que em média foi aumentada em 0,5 milímetros durante o tratamento. O comprimento do arco foi aumentado em média 2,6 milímetros, durante o tratamento, e na pós-contenção reduziu-se para 3,6 milímetros. A largura intermolar foi aumentada em média 1,4 milímetros, durante o 
tratamento, e na pós-contenção reduziu-se para 0,7 milímetros. A redução no comprimento do arco, não foi relacionada ao aumento da irregularidade nos incisivos inferiores.

\subsection{4 - Dimensões do arco inferior e o desenvolvimento da oclusão}

SINCLAIR; LITTLE ${ }^{115}$, em 1983 avaliaram os modelos dentários de 65 pacientes que apresentavam oclusões normais não tratadas, a fim de descrever a natureza e extensão das mudanças vistas durante o desenvolvimento da oclusão, da dentadura mista até dentição permanente nos adultos. O comprimento do arco diminuiu 2,88 milímetros, da dentadura mista (9-10 anos), até a dentição permanente jovem (12-13 anos), e diminuiu em média 1,95 milímetros, do início da dentição permanente até a fase de adulto jovem (19-20 anos). A distância intercaninos diminui 0,30 milímetros da dentadura mista (9-10 anos), até a dentição permanente jovem ( 12-13 anos), e diminuiu em média 0,44 milímetros, do início da dentição permanente até a fase de adulto jovem (19-20 anos). A distância intermolares se manteve estável da dentadura mista (9-10 anos), até a dentição permanente jovem ( 12-13 anos), e diminuiu muito pouco $(0,10$ milímetros $)$, do início da dentição permanente até a fase de adulto jovem (19-20 anos).As mudanças individuais encontradas, não foram correlacionadas com nenhum outro parâmetro medido, sugerindo que as mudanças destes parâmetros avaliados são independentes. Os autores ${ }^{115}$ concluem, que alterações na forma do arco no período de pós-contenção, em pacientes tratados ortodonticamente, não são necessariamente conseqüência da terapia ortodôntica em 
si, mas do próprio processo de maturação da oclusão destes pacientes. Notou-se esta mesma tendência em outros estudos $9,16,18,19,23,26,39,75,83,97,98,99$.

Como demonstrado nesta revisão, existem dúvidas quanto à estabilidade da correção do apinhamento ântero-inferior a longo prazo, no que diz respeito à forma de abordagem com e sem extrações de pré-molares no arco inferior, em pacientes portadores de má oclusão de Classe II de Angle. Isso se aplica especialmente em casos em que a quantidade de apinhamento é suave ou moderada, em que o fato de não se extrair pré-molares, terá como resultado, mesmo se forem utilizados procedimentos de desgastes interproximais ("stripping"), expansões no arco inferior. Estas expansões no arco inferior mediadas pelo tratamento ortodôntico, na fase de pós-contenção, seriam perdidas, e fatalmente redundariam na recidiva do alinhamento dos dentes ântero-inferiores. Por outro lado, a literatura mais dogmática, sustenta que a expansão do arco inferior somente seria estável com a extrações de pré-molares neste arco, e esta conduta proporcionaria o alcance de uma maior estabilidade da correção do apinhamento ântero-inferior, muito embora notou-se que as extrações de pré-molares não garantem uma maior a estabilidade do alinhamento ântero-inferior. Portanto, tendo em vista estas duas correntes vigentes na ciência ortodôntica, considerou-se importante uma pesquisa que comparasse a estabilidade pós-contenção da correção do apinhamento ântero-inferior, entre estas duas formas de abordagem da má oclusão de Classe II de Angle, ou seja, com a extração de dois pré-molares (sem extrações no arco inferior) ou de quatro pré- molares. Também, foi comparada a estabilidade a longo prazo, das alterações na forma do arco inferior promovida por estes dois enfoques terapêuticos da Classe II. Estes resultados auxiliarão o ortodontista em sua decisão no plano de tratamento, principalmente, já 
se levando em conta, antes mesmo de se iniciar o tratamento em si, a estabilidade que pode ser esperada para cada um dos dois tipos de abordagem da Classe II (com e sem extrações no arco inferior). 
3-Proposição 


\section{3 - PROPOSIÇÃO}

O objetivo deste trabalho é testar a seguinte hipótese nula:

"Não há diferença na quantidade de recidiva pós-contenção do apinhamento ântero-inferior e das alterações da forma do arco inferior póstratamento, para pacientes portadores de má oclusão Classe II de Angle, tratados com duas ou com quatro extrações de pré-molares”. Para tanto, serão comparados o índice de Little inferior, o comprimento e a largura do arco inferior, nas fases de prétratamento, final de tratamento e cinco anos pós-tratamento, e suas alterações entre essas fases, para os dois grupos tratados com essas diferentes abordagens. 
4-Material e Métodos 


\section{4 - MATERIAL E MÉTODOS}

\section{1 - MATERIAL}

A amostra foi obtida, na sua totalidade, a partir dos arquivos da Disciplina de Ortodontia da Faculdade de Odontologia de Baurt- Universidade de São Paulo. Os pacientes apresentavam registros completos e foram selecionados de acordo com o critério de serem portadores de no mínimo, uma má oclusão de uma meia Classe II de Angle, sendo que de acordo com a severidade, os pacientes escolhidos mostravam inicialmente, uma relação de meia Classe II até uma Classe II completa. Os pacientes deviam apresentar ao início do tratamento todos os dentes permanentes até os primeiros molares, e ausência de anodontias e supranumerários, examinados na radiografia ortopantomográfica inicial.

A amostra foi dividida em dois grupos de acordo com a modalidade de tratamento da Classe II, ou seja, tratamentos com extração de dois pré-molares superiores(grupo 1) e tratamentos executados com a extração de quatro pré-molares (grupo 2). O grupo 1 foi composto por 19 pacientes, sendo 9 do gênero masculino e 10 do gênero feminino, com média de idade de 14,04 anos e des vio padrão de 1,74 anos. O tempo médio de duração do tratamento foi de 2,41 anos (D.P.: 0,88 anos), e o tempo médio de observação pós-tratamento foi de 5,17 anos (D.P.: 2,40 anos). O grupo 2 foi composto por 47 pacientes, sendo 20 do gênero masculino e 27 do gênero feminino, com média de idade de 13,03 anos, e desvio padrão de 1,76 anos. O tempo 
médio de duração do tratamento foi de 2,70 anos (D.P.: 0,70 anos), e o tempo médio de observação pós-tratamento foi de 5,91 anos (D.P.: 2,75 anos).

Todos os pacientes foram tratados com mecânica do arco de Canto, sendo que as extrações foram executadas logo após a montagem da ancoragem, e o tratamento começou, em seguida a este procedimento. Dez dos dezenove pacientes do grupo 1, foram submetidos a técnica de desgaste interproximal preconizada por SHERIDAN $^{109}$, a fim de obter-se espaço para a correção do apinhamento inferior. Após o término do tratamento corretivo, seguiu-se a fase de contenção, que consistiu no uso, para todos os pacientes, de uma barra lingual inferior $3 \mathrm{X} 3$ colada ou com bandas, e contenção móvel tipo placa de Hawley no arco superior. Estas contenções foram usadas seguindo o protocolo recomendado pela Disciplina de Ortodontia da FOB-USP, que é de seis meses com uso contínuo, e mais seis meses de uso noturno para a placa de Hawley, e em média de 2 anos, para a contenção fixa 3 X3 colada no arco inferior, sendo que estas contenções foram removidas na seqüência.

Os dados foram coletados a partir de três modelos inferiores dos pacientes, em períodos correspondentes ao início do tratamento, final do tratamento, e período pós-tratamento médio de 5 anos, sendo este último relativo ao registro do modelo inferior sem a presença da barra lingual $(3 \times 3)$ colada. A qualidade dos resultados pós-tratamento e pós-contenção, não foram considerados no processo de seleção, ou para inclusão ou exclusão na amostra. Na verdade todos os esforços foram executados para coletar registros e dados sem influências. 


\section{2 - MÉTODOS}

\subsection{1 - Medidas no Modelo Inferior}

Para quantificar o apinhamento ântero-inferior, foi utilizado um paquímetro digital (com precisão de $0,01 \mathrm{~mm}$ ) posicionado paralelamente ao plano oclusal. Obtêm-se desta forma, o deslocamento dos cinco pontos de contato na região de canino inferior direito a canino inferior esquerdo. O somatório do deslocamento dos pontos de contato, fornece o índice de irregularidade, como descrito por LITTLE ${ }^{66}$, índice este medido para cada modelo inferior nos três períodos de tempo avaliados (figura 4.1 ).

Também foram coletadas as seguintes medidas nos três modelos inferiores de cada paciente :

- Largura intercaninos inferior: distância em milímetros (paquímetro) entre a ponta das cúspides dos caninos inferiores, ou entre as pontas de cúspide estimadas no caso em que facetas de desgaste estavam presentes (Figura 4.2).

- Comprimento do arco inferior: somatório da distância do ponto de contato anatômico mesial dos primeiros molares permanentes direito e esquerdo, ao ponto de contato dos incisivos centrais. A medida do comprimento de arco foi feita de acordo com NANCE ${ }^{84}$ (Figura 4.2). 
- Largura intermolares inferior : distância entre a a ponta da cúspide mésio-vestibular do $1^{\circ}$ molar inferior direito e a mesma referência anatômica do $1^{\circ}$ molar do lado oposto(Figura 4.2).

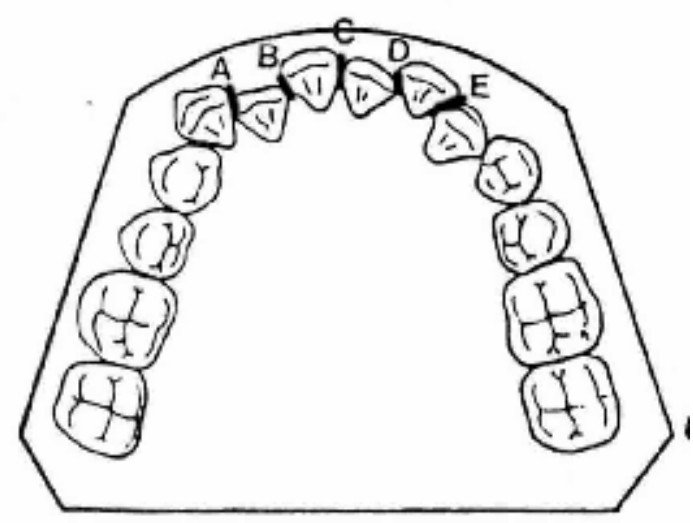

$\mathrm{A}+\mathrm{B}+\mathrm{C}+\mathrm{D}+\mathrm{E}=$ Indice de Irregularidade

FIGURA 4.1 - Técnica de medição dos modelos Reproduzido de LITTLE ${ }^{65}$

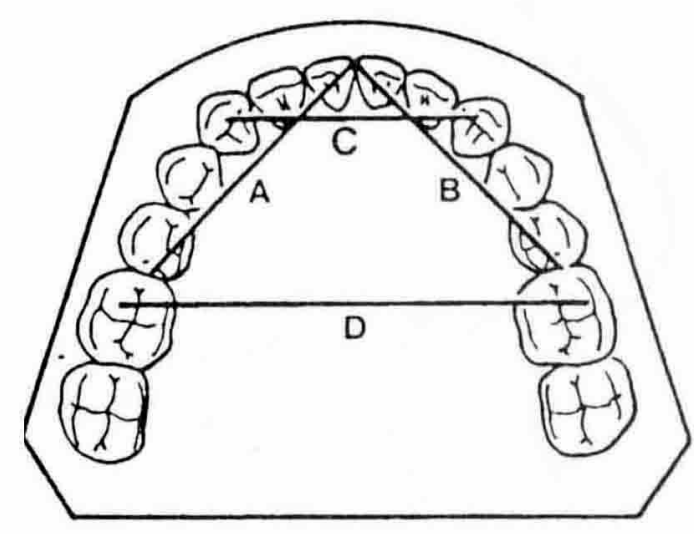

$\mathrm{A}+\mathrm{B}=$ Comprimento do Arco

$\mathrm{C}=$ Distância Intercaninos

$\mathrm{D}=$ Distância Intermolares

FIGURA 4.2 - Técnica de medição dos modelos Reproduzido de LITLE ${ }^{66}$ 


\subsection{2 - Análise Estatística}

\subsubsection{1 - Erro do Método}

Para a avaliação do erro intra-examinador, foram realizadas novamente todas as medidas nos modelos de dezesseis pacientes de ambos os grupos, selecionados aleatoriamente, somando-se um total de quarenta e oito modelos inferiores. A aplicação da fórmula proposta por DAHLBERG ${ }^{31}\left(\mathrm{Se}^{2}=\right.$ somatória $d^{2} / 2 n$ ), permitiu estimar a ordem de grandeza dos erros casuais. A obtenção dos erros sistemáticos procedeu-se pela aplicação do teste $\mathrm{t}$ pareado, de acordo com HOUSTON $^{53}$ (1983).

\subsubsection{2 - Comparação entre os Grupos}

\subsubsection{1 -Teste t para variáveis independentes}

Para a análise estatística dos dados utilizou-se $\mathrm{o}$ teste $\mathrm{t}$ para variáveis independentes. Para a utilização do teste t, torna-se necessário que a distribuição das variáveis seja normal, constatação esta, obtida pelo teste de Kolmogorov-Smirnov, para cada uma das variáveis (Índice de Little, Largura Intercaninos, Largura Intermolares e Comprimento de Arco). Portanto, o teste $\mathrm{t}$ foi utilizado para a comparação das variáveis ao inicio, ao final do tratamento e cinco anos pós-tratamento, e para comparar as alterações ocorridas entre nos três períodos avaliados, para os dois grupos. Estes testes foram realizados com o programa 
Statistica $^{\mathrm{a}}$. Os resultados foram considerados estatisticamente significantes para $\mathrm{p}<0,05$.

Como a presença de um apinhamento ântero-inferior inicial maior no grupo 2, pode influenciar na decisão de extrações no arco inferior neste grupo, bem como no comportamento dos dentes ântero-inferiores a longo prazo, realizourse a eliminação de 16 pacientes deste grupo, pacientes estes que apresentaram os maiores apinhamentos, de forma que foi estabelecido um subgrupo 2, com apinhamento inicial compatível com o grupo 1. Isto permitiu que as duas modalidades de tratamento fossem comparadas a partir de uma paridade inicial da variável em questão. O mesmo teste t foi utilizado para a comparação das variáveis supracitadas ao inicio, ao final do tratamento e cinco anos pós-tratamento, e para comparar as alterações ocorridas entre nos três períodos avaliados, para os o grupo 1 e o subgrupo 2.

${ }^{\text {a }}$ Statistica for Windows - Release 4.3B. — Copyright Statsoft, lnc. 1993. 
5-Resultados 


\section{5 - RESULTADOS}

Os resultados estão apresentados sob a forma de tabelas. Na tabela

5.1 estão dispostos os valores dos erros casuais e sistemáticos, da avaliação intraexaminador. A tabela 5.2 apresenta os resultados do teste $\mathrm{t}$ para variáveis independentes, da comparação dos grupos 1 e 2. A tabela 5.3 mostra o resultado do teste $\mathrm{t}$ independente, entre os grupos 1 e 2, para as alterações das variáveis nos diferentes período de avaliação.

Tabela 5.1 - Apresentação dos erros casuais (Dahlberg) e dos resultados do teste $\mathrm{t}$ para amostras dependentes, do teste intra-examinador.

\begin{tabular}{|c|c|c|c|c|c|c|}
\hline \multirow[t]{2}{*}{ Variáveis } & \multicolumn{2}{|c|}{$1^{a}$ medição } & \multicolumn{2}{|c|}{$2^{a}$ Medição } & \multirow[b]{2}{*}{ Dahlberg } & \multirow[b]{2}{*}{$\mathrm{p}$} \\
\hline & Média & D.P. & Média & D.P. & & \\
\hline I.de Little (I) & 3,77 & 3,15 & 3,78 & 3,23 & 0,09 & 0,92 \\
\hline $\begin{array}{l}\text { I.deLittle } \\
\text { (F) }\end{array}$ & 1,13 & 0,85 & 1,26 & 0,91 & 0,08 & 0,25 \\
\hline $\begin{array}{l}\text { I.deLittle } \\
\text { (PC) }\end{array}$ & 2,39 & 2,13 & 2,40 & 2,19 & 0,04 & 0,89 \\
\hline $3 \times 3$ (I) & 25,37 & 1,32 & 25,45 & 1,09 & 0,06 & 0,41 \\
\hline $3 \times 3(F)$ & 25,84 & 2,03 & 25,89 & 1,86 & 0,06 & 0,59 \\
\hline $3 \times 3(P C)$ & 24,78 & 2,11 & 24,78 & 1,95 & 0,03 & 0,95 \\
\hline $6 \times 6(I)$ & 36,69 & 2,49 & 36,84 & 2,44 & 0,04 & 0,06 \\
\hline $6 \times 6(F)$ & 36,20 & 2,31 & 36,39 & 2,27 & 0,09 & 0,08 \\
\hline $6 \times 6(P C)$ & 36,01 & 2,75 & 35,96 & 2,57 & 0,11 & 0,73 \\
\hline $\begin{array}{l}\text { Comp. Arco } \\
\text { (I) }\end{array}$ & 56,11 & 3,48 & 54,64 & 7,72 & 2,43 & 0,38 \\
\hline $\begin{array}{l}\text { Comp. } \\
\operatorname{Arco}(F)\end{array}$ & 51,20 & 5,2 & 51,22 & 4,97 & 1,16 & 0,94 \\
\hline $\begin{array}{l}\text { Comp. } \\
\operatorname{Arco}(P)\end{array}$ & 49,24 & 5,36 & 49,71 & 5,19 & 1,52 & 0,31 \\
\hline
\end{tabular}


Tabela 5.2 - Resultado do teste $\mathrm{T}$ independente, entre os grupos 1 e 2 .

\begin{tabular}{|c|c|c|c|c|c|c|}
\hline \multirow[t]{2}{*}{ Variáveis } & \multicolumn{2}{|c|}{ Grupo 1} & \multicolumn{2}{|c|}{ Grupo 2} & & \\
\hline & Média & D.P. & Média & D.P. & gl & $\mathrm{p}$ \\
\hline Idade & 14,04 & 1,74 & 13,03 & 1,76 & 64 & $0,04 *$ \\
\hline $\begin{array}{l}\text { Duração do } \\
\text { tratamento }\end{array}$ & 2,41 & 0,88 & 2,70 & 0,70 & 64 & 0,16 \\
\hline $\begin{array}{l}\text { Controle } \\
\text { Pós- } \\
\text { tratamento }\end{array}$ & 5,17 & 2,40 & 5,91 & 2,75 & 64 & 0,31 \\
\hline I.de Little (I) & 3,23 & 1,67 & 5,25 & 3,91 & 64 & $0,03 *$ \\
\hline $\begin{array}{l}\text { I.deLittle } \\
\text { (F) }\end{array}$ & 1,66 & 1,54 & 1,13 & 0,74 & 64 & 0,06 \\
\hline $\begin{array}{l}\text { I.deLittle } \\
(P C)\end{array}$ & 2,21 & 1,43 & 2,11 & 1,66 & 64 & 0,81 \\
\hline $3 \times 3(I)$ & 25,67 & 1,76 & 25,70 & 2,04 & 64 & 0,96 \\
\hline $3 \times 3(F)$ & 25,41 & 1,92 & 26,62 & 1,38 & 64 & $0,00 *$ \\
\hline $3 \times 3(P C)$ & 24,71 & 1,76 & 25,67 & 1,55 & 64 & $0,03 *$ \\
\hline $6 \times 6(I)$ & 39,82 & 2,98 & 38,55 & 2,31 & 64 & 0,06 \\
\hline $6 \times 6(F)$ & 39,14 & 2,51 & 36,40 & 1,98 & 64 & $0,00^{*}$ \\
\hline $6 \times 6(P C)$ & 39,26 & 3,20 & 36,51 & 2,17 & 64 & $0,00 *$ \\
\hline $\begin{array}{l}\text { Comp. Arco } \\
\text { (I) }\end{array}$ & 59,20 & 4,17 & 57,87 & 3,83 & 64 & 0,21 \\
\hline $\begin{array}{l}\text { Comp. } \\
\operatorname{Arco}(F)\end{array}$ & 59,21 & 4,24 & 49,42 & 2,99 & 64 & $0,00 *$ \\
\hline $\begin{array}{l}\text { Comp. } \\
\operatorname{Arco}(P)\end{array}$ & 57,95 & 3,99 & 47,81 & 2,92 & 64 & $0,00 *$ \\
\hline
\end{tabular}


Tabela 5.3 - Resultado do teste $\mathrm{T}$ independente, entre os grupos 1 e 2, para as alterações das variáveis nos diferentes período de avaliação.

\begin{tabular}{|c|c|c|c|c|c|c|}
\hline \multirow[t]{2}{*}{ Variáveis } & \multicolumn{2}{|c|}{ Grupo 1} & \multicolumn{2}{|c|}{ Grupo 2} & \multirow[b]{2}{*}{ gl } & \multirow[b]{2}{*}{ p } \\
\hline & Média & D.P. & Média & D.P. & & \\
\hline $\begin{array}{l}\text { I.Little } \\
(F-I)\end{array}$ & $-1,57$ & 1,81 & $-4,12$ & 3,94 & 64 & $0,00^{*}$ \\
\hline $\begin{array}{l}\text { I.Little } \\
(P C-F)\end{array}$ & 0,55 & 0,89 & 0,97 & 1,77 & 64 & 0,32 \\
\hline $\begin{array}{l}\text { I.Little (PC- } \\
\text { I) }\end{array}$ & $-1,02$ & 1,76 & $-3,14$ & 4,23 & 64 & $0,03 *$ \\
\hline $\begin{array}{l}3 \times 3 \\
(F-I)\end{array}$ & $-0,27$ & 1,49 & 0,92 & 1,87 & 64 & $0,01 *$ \\
\hline $\begin{array}{l}3 \times 3 \\
(P C-F)\end{array}$ & $-0,69$ & 0,99 & $-0,95$ & 0,98 & 64 & 0,33 \\
\hline $\begin{array}{l}3 \times 3 \\
(P C-I)\end{array}$ & $-0,96$ & 0,92 & $-0,03$ & 1,96 & 64 & 0,05 \\
\hline $\begin{array}{l}6 \times 6 \\
(F-I)\end{array}$ & $-0,68$ & 1,87 & $-2,15$ & 1,87 & 64 & $0,00^{*}$ \\
\hline $\begin{array}{l}6 \times 6 \\
(P C-F)\end{array}$ & 0,12 & 1,26 & 0,11 & 1,02 & 64 & 0,96 \\
\hline $\begin{array}{l}6 \times 6 \\
(P C-I)\end{array}$ & $-0,56$ & 1,81 & $-2,04$ & 1,90 & 64 & $0,00 *$ \\
\hline $\begin{array}{l}\text { C.A. } \\
(F-I)\end{array}$ & 0,01 & 2,31 & $-8,45$ & 2,94 & 64 & $0,00 *$ \\
\hline $\begin{array}{l}\text { C.A. } \\
(P C-F)\end{array}$ & $-1,26$ & 1,60 & $-1,60$ & 1,45 & 64 & 0,40 \\
\hline $\begin{array}{l}\text { C.A. } \\
(P C-I) \\
\end{array}$ & $-1,25$ & 2,09 & $-10,05$ & 3,11 & 64 & $0,00 *$ \\
\hline
\end{tabular}

Os resultados do teste t para variáveis independentes entre os casos com apinhamento inicial compatível do grupo 1 e subgrupo 2, estão dispostos na Tabela 5.4. A tabela 5.5, mostra o resultado do teste $t$ independente, entre o grupo 1 e subgrupo 2, com apinhamento inicial compatível, para as alterações das variáveis nos diferentes período de avaliação. 
Tabela 5.4 - Resultado do teste $\mathrm{T}$ independente, entre o grupo 1 e o subgrupo 2, com apinhamento inicial compatível.

\begin{tabular}{|c|c|c|c|c|c|c|}
\hline \multirow[t]{2}{*}{ Variáveis } & \multirow{2}{*}{$\begin{array}{r}\text { Grupo } 1 \\
\text { Média } \\
\end{array}$} & \multicolumn{3}{|c|}{ Subgrupo 2} & \multirow[b]{2}{*}{$\mathrm{gl}$} & \multirow[b]{2}{*}{$\mathrm{p}$} \\
\hline & & D.P. & Média & D.P. & & \\
\hline Idade & 14,04 & 1,74 & 12,91 & 1,74 & 48 & $0,03 *$ \\
\hline $\begin{array}{l}\text { Duração do } \\
\text { tratamento }\end{array}$ & 2,41 & 0,88 & 2,69 & 0,66 & 48 & 0,20 \\
\hline $\begin{array}{l}\text { Controle } \\
\text { Pós- } \\
\text { tratamento }\end{array}$ & 5,17 & 2,40 & 6,33 & 2,84 & 48 & 0,14 \\
\hline I.de Little (I) & 3,23 & 1,67 & 3,06 & 1,47 & 48 & 0,71 \\
\hline $\begin{array}{l}\text { I.deLittle } \\
\text { (F) }\end{array}$ & 1,66 & 1,54 & 1,03 & 0,68 & 48 & 0,05 \\
\hline $\begin{array}{l}\text { I.deLittle } \\
(P C)\end{array}$ & 2,21 & 1,43 & 2,11 & 1,88 & 48 & 0,84 \\
\hline $3 \times 3(I)$ & 25,67 & 1,76 & 26,01 & 1,54 & 48 & 0,48 \\
\hline $3 \times 3(F)$ & 25,41 & 1,92 & 26,55 & 1,20 & 48 & $0,01 *$ \\
\hline $3 \times 3(P C)$ & 24,71 & 1,76 & 25,44 & 1,35 & 48 & 0,10 \\
\hline $6 \times 6(I)$ & 39,82 & 2,98 & 38,81 & 2,38 & 48 & 0,19 \\
\hline $6 \times 6(F)$ & 39,14 & 2,51 & 36,28 & 2,03 & 48 & $0,00 *$ \\
\hline $6 \times 6(P C)$ & 39,26 & 3,20 & 36,55 & 2,14 & 48 & $0,00 *$ \\
\hline $\begin{array}{l}\text { Comp. Arco } \\
\text { (I) }\end{array}$ & 59,20 & 4,17 & 58,90 & 3,57 & 48 & 0,78 \\
\hline $\begin{array}{l}\text { Comp. } \\
\operatorname{Arco}(F)\end{array}$ & 59,21 & 4,24 & 49,35 & 2,43 & 48 & $0,00 *$ \\
\hline $\begin{array}{l}\text { Comp. } \\
\operatorname{Arco}(P)\end{array}$ & 57,95 & 3,99 & 47,40 & 2,55 & 48 & $0,00 *$ \\
\hline
\end{tabular}


Tabela 5.5 - Resultado do teste $\mathrm{T}$ independente, entre o grupo 1 e o subgrupo 2 com apinhamento inicial compatível, para as alterações das variáveis nos diferentes período de avaliação.

\begin{tabular}{|c|c|c|c|c|c|c|}
\hline \multirow[t]{2}{*}{ Variáveis } & \multicolumn{2}{|c|}{ Grupo 1} & \multicolumn{2}{|c|}{ Subgrupo 2} & \multirow[b]{2}{*}{$\mathrm{gl}$} & \multirow[b]{2}{*}{$\mathrm{p}$} \\
\hline & Média & D.P. & Média & D.P. & & \\
\hline $\begin{array}{l}\text { I.Little } \\
(F-I)\end{array}$ & $-1,57$ & 1,81 & $-2,03$ & 1,61 & 48 & 0,35 \\
\hline $\begin{array}{l}\text { I.Little } \\
\text { (PC-F) }\end{array}$ & 0,55 & 0,89 & 1,08 & 1,97 & 48 & 0,27 \\
\hline $\begin{array}{l}\text { I. Little (PC- } \\
\text { I) }\end{array}$ & $-1,02$ & 1,76 & $-0,95$ & 1,92 & 48 & 0,89 \\
\hline $\begin{array}{l}3 \times 3 \\
(F-I)\end{array}$ & $-0,27$ & 1,49 & 0,55 & 1,60 & 48 & 0,07 \\
\hline $\begin{array}{l}3 \times 3 \\
(P C-F)\end{array}$ & $-0,69$ & 0,99 & $-1,11$ & 1,04 & 48 & 0,16 \\
\hline $\begin{array}{l}3 \times 3 \\
(P C-I)\end{array}$ & $-0,96$ & 0,92 & $-0,56$ & 1,40 & 48 & 0,27 \\
\hline $\begin{array}{l}6 \times 6 \\
(F-I)\end{array}$ & $-0,68$ & 1,87 & $-2,53$ & 1,84 & 48 & $0,00 *$ \\
\hline $\begin{array}{l}6 \times 6 \\
(P C-F)\end{array}$ & 0,12 & 1,26 & 0,26 & 1,08 & 48 & 0,67 \\
\hline $\begin{array}{l}6 x 6 \\
(P C-I)\end{array}$ & $-0,56$ & 1,81 & $-2,27$ & 1,94 & 48 & $0,00 *$ \\
\hline $\begin{array}{l}\text { C. } A \text {. } \\
(F-I)\end{array}$ & 0,01 & 2,31 & $-9,55$ & 2,32 & 48 & $0,00 *$ \\
\hline $\begin{array}{l}\text { C.A. } \\
(P C-F)\end{array}$ & $-1,26$ & 1,60 & $-1,95$ & 1,05 & 48 & 0,07 \\
\hline $\begin{array}{l}\text { C.A. } \\
(P C-I)\end{array}$ & $-1,25$ & 2,09 & $-11,51$ & 1,99 & 48 & $0,00 *$ \\
\hline
\end{tabular}


6-Discussão 


\section{6 - DISCUSSÃO}

Com o propósito de facilitar o entendimento e interpretação dos resultados obtidos com esta pesquisa, serão discutidos seqüencialmente, a amostra utilizada, a metodologia empregada, a precisão da metodologia, os resultados obtidos com relação à recidiva do apinhamento nas amostras tratadas com e sem extração no arco inferior, e as alterações na forma do arco inferior (largura intercaninos, largura intermolares e comprimento de arco) no período do tratamento ortodôntico e na fase de pós-contenção, considerando-se as duas alternativas de tratamento da Classe II que estão sendo abordadas. Adicionalmente, baseado nos resultados e na literatura consultada, se discute as implicações clínicas destes achados no tratamento da má oclusão de Classe II de Angle.

\section{1 - AMOSTRA UTILIZADA}

Para obtenção da amostra foram selecionados os modelos de grupos de pacientes que apresentassem inicialmente no mínimo, uma relação molar de meia Classe II de ambos os lados, e tratados com a mecânica ortodôntica fixa com a extração de dois pré-molares superiores ${ }^{30,87}$,ou de dois pré-molares superiores e de dois inferiores ${ }^{67,131}$. Não houve a preocupação em se diferenciar se foram extraídos primeiros ou segundos pré-molares nos casos a serem avaliados, pois todos os casos preencheram os requisitos, e a probabilidade de extrações de segundos prémolares serem encontrados nos diferentes grupos era semelhante. Casos com relação 
molar de Classe II que apresentassem subdivisões foram eliminados da amostra com o objetivo de não incorporar outras variáveis que poderiam interferir nos resultados finais, uma vez que isso implicaria em mecânicas assimétricas para a correção do problema, que não se constituíam em objetivo deste estudo ${ }^{13,32,54}$. Como o objetivo era a comparação da estabilidade de dois protocolos de tratamento para a má oclusão de Classe II, principalmente da correção do apinhamento inferior, era condição imprescindível que essa discrepância sagital fosse semelhante em ambos os grupos.

Outro critério utilizado foi a presença de todos os dentes permanentes até os segundos molares. A ausência de algum dente pode, em determinadas situações, favorecer ou complicar a correção dessa má oclusão (Classe II com apinhamento ântero-inferior) e isso poderia interferir nos resultados também ${ }^{132}$.

Também foi requisito para inclusão nesta amostra, o paciente deveria ter modelo de controle pós-contenção, ou seja, sem contenção fixa 3x3 inferior por um período médio de pelo menos 3 anos.

Portanto, satisfazendo esses critérios, foram encontrados um total de 66 pacientes, sendo 19 do grupo 1 e 47 do grupo 2, dentre um total de 2.000 pacientes já tratados nos cursos de pós-graduação, especialização e atualização da Disciplina de Ortodontia da Faculdade de Odontologia de Bauru, e dois pacientes deste total foram obtidos na Universidade Estadual do Oeste do Paraná. Pode parecer pouco dentro da proporção de pacientes com má oclusão de Classe II que geralmente constituem o universo de uma clínica ortodôntica ${ }^{94}$, principalmente do grupo 1. Entretanto, deve-se lembrar que os critérios estabelecidos eliminaram uma grande 
parte dos pacientes potenciais. Adicionalmente, convém mencionar que apesar dos esforços para o arquivamento de toda documentação dos pacientes tratados na disciplina, havia alguns casos que não apresentavam todos os modelos para serem incluídos nessa avaliação. No caso do grupo 1, devido a opção terapêutica por duas extrações na Classe II ter sido aceita mais recentemente, haviam poucos modelos de controles, e aqueles que apresentavam modelos de controle, ainda tinham a contenção fixa colada no arco inferior, e desta forma não puderam ser incluídos. Notou-se um que grande número de pacientes tratados com a extração de dois prémolares, faziam parte do grupo tratado na especialização, e neste arquivo há pouco controle pós-tratamento. Mesmo fazendo contato telefônico para executar a moldagem de controle, poucos (apenas quatro), se dispuseram a vir até a faculdade para a realização deste exame.

As idades médias dos pacientes dos dois grupos apresentaram-se estatisticamente diferentes (Tabela 2). O fato do grupo com extrações dos dois prémolares superiores apresentar a média de idade ligeiramente superior ao grupo com extrações dos quatro pré-molares é compreensível. Sabe-se que quanto mais avançada a idade do paciente, mais difícil é a correção da relação ântero-posterior dos arcos dentários, porque o potencial de crescimento diminui progressivamente com a idade. Como os casos de extrações de quatro primeiros pré-molares necessitarão de uma maior correção ântero-posterior, é evidente que esse protocolo de extrações terá uma aplicação mais restrita com o avançar da idade dos pacientes. Por outro lado, o protocolo de extrações de dois pré-molares superiores pode ser utilizado mais freqüentemente em faixas etárias mais avançadas ${ }^{46,89}$. Muito embora, 
se tivesse esta diferença entre os grupos para as faixas etárias, houve uma compatibilidade para o tempo de controle pós-tratamento (tabela 2).

\section{2 - METODOLOGIA}

A melhor forma de avaliação do grau inicial de severidade da má oclusão e do resultado oclusal obtido seria evidentemente pela avaliação clínica direta de cada paciente ${ }^{62}$. A base para esta afirmativa, segundo LEWIS ${ }^{62}$ está na proximidade clínica que o profissional tem com o paciente refletindo assim mais completamente a situação da má oclusão e a necessidade de tratamento envolvida nos casos individualizados. Entretanto, esse tipo de avaliação seria praticamente impossível de ser realizada por se tratar de um estudo retrospectivo. O primeiro problema seria entrar em contato com os pacientes, após muitos anos do término de seu tratamento. Muitos podem ter mudado de endereço, telefone e até de cidade. Mesmo que se conseguisse o comparecimento de um número significante deles, a avaliação do término do tratamento estaria comprometida por possíveis recidivas que tivessem ocorrido ou ainda por perdas dentárias subsequentes ${ }^{68,132}$.

Optou-se avaliação dos modelos permite uma melhor visualização dos posicionamentos presentes, antes e após o tratamento. Por essas razões é que se optou pela avaliação dos modelos iniciais e finais e de controle dos arquivos da Disciplina de Ortodontia.

Para se avaliar o apinhamento inferior no modelo de gesso, existem várias formas $^{55,66,85}$. Entretanto, para verificação mais precisa da melhor estabilidade 
da correção do apinhamento inferior obtido entre as duas formas de tratamento selecionadas, se priorizou a forma de avaliação de modelos de gesso por meio de um índice de irregularidade de LITTLE $^{66}$, e também por meio da análise de variáveis individualmente, no mesmo modelo.

O índice de irregularidade, elaborado por LITTLE ${ }^{66}$ foi escolhido dentre outros índices apinhamento pesquisados ${ }^{55,85}$, por permitir uma avaliação em modelos de gesso, por ser altame nte reproduzível e confiável, e por ser o índice mais utilizado nos artigos relativos à recidiva do apinhamento ântero-inferior, encontrados na literatura ortodôntica. Portanto, por meio desse índice tornourse possível realizar a avaliação da severidade do apinhamento inferior previamente ao tratamento ortodôntico, a condição desta variável ao final do tratamento e em média cinco anos após o término do tratamento ativo, e as alterações ocorridas entre os períodos avaliados, para posterior comparação entre os dois grupos selecionados.

Para complementar esse estudo, foram também realizadas mensurações individuais do comprimento e da largura do arco inferior, nos três modelos de gesso estudados para cada paciente, em ambos os grupos. Essas medições individuais foram realizadas para avaliar, se havia uma diferença entre os dois protocolos de tratamento, para as alterações promovidas nestas variáveis durante o tratamento e o comportamento destas no período de pós-tratamento. 


\section{3 - PRECISÃO DA METODOLOGIA}

Foram realizadas nove mensurações em cada um dos modelos iniciais, finais e de cinco anos pós-tratamento de ambos os grupos de pacientes selecionados na amostra. Como a amostra total conta com 66 pacientes e cada paciente consta de três pares de modelos, ao final foram então medidos 198 pares de modelos, totalizando 1782 medidas.

Para avaliar os erros da metodologia, HOUSTON ${ }^{53}$ recomenda, idealmente, que as medições sejam realizadas duas vezes. Entretanto, se isto não for possível, aconselha que os modelos sejam selecionados ao acaso, da amostra total. Neste estudo, foram medidos novamente dezesseis modelos inferiores, escolhidos ao acaso, número esse julgado suficiente devido à quantidade de variáveis utilizadas e com base em estudos similares que utilizaram quantidades semelhantes.

A maior fonte de erros casuais, segundo $\operatorname{HOUSTON}^{53}$, acontece pela dificuldade de identificação de um ponto em particular ou pela imprecisão na definição de certos pontos. De uma forma geral, os erros casuais nesse trabalho foram bastante reduzidos, exceto para o comprimento do arco inicial, que foi de 2,43 milímetros, o que mesmo assim pode ser considerado bastante satisfatório, ao se comparar com a literatura ${ }^{62,122}$ (Tabela 1). O maior significado dos erros casuais refere-se ao seu poder de aumentar o desvio-padrão das médias obtidas ${ }^{31}$. Como os erros casuais para as variáveis em estudo foram bastante pequenos, conclui-se que os desvios padrão encontrados para elas sejam realmente o reflexo da variabilidade dos grupos. 
No entanto, não houve diferenças estatisticamente significantes na avaliação do erro sistemático $(\mathrm{p}<0,05)$, em nenhuma das variáveis avaliadas. Os erros sistemáticos se manifestam quando um determinado parâmetro é persistentemente sub ou superestimado, podendo ocorrer quando um pesquisador modifica a sua técnica de mensuração após certo tempo, ou então quando ele tende, subconscientemente, a direcionar os resultados de acordo com as suas expectativas em relação às conclusões do estudo ${ }^{53}$.

\section{4 - RESULTADOS}

\subsection{1 - Compatibilidade dos grupos}

Mesmo selecionando os pacientes de ambos os grupos de acordo com os critérios mencionados, há possibilidade dos mesmos apresentarem outras características que possam dificultar a mecânica selecionada. Dessa forma, com a intenção de minimizar essa possibilidade, foram comparadas as variáveis a serem estudadas, previamente ao tratamento. Percebe-se pela Tabela 2 que, com exceção do grau de apinhamento iniciais, todas as demais variáveis não apresentaram diferenças estatisticamente significantes entre os grupos. Isso demonstra um alto grau de compatibilidade entre os grupos estudados e isenção da interferência de características díspares nos resultados.

Entretanto, a diferença estatisticamente significante entre o apinhamento inicial dos grupos poderia influir na decisão do tratamento entre os dois protocolos, bem como no comportamento pós-contenção do alinhamento dos dentes 
ântero-inferiores, e conseqüentemente nos resultados dessa comparação. Por esse motivo, é que o grupo 2 foi dividido em subgrupo 2, sendo que através da eliminação dos casos mais apinhados do grupo 2, pode-se realizar o teste t entre o grupo 1 e o subgrupo 2, para dirimir qualquer dúvida que pudesse emergir, devido à essa diferença entre os graus de apinhamento iniciais (tabela 4).

\subsection{2 - Recidiva do Apinhamento Ântero-inferior}

“...nós podemos ficar orgulhosos com os resultados maravilhosos que, na maioria das vezes, somos capazes de alcançar. Mas na sequência, de que vale este prazer e satisfação temporário para nós e nossos pacientes, se encontramos em poucos anos, que a maioria dos casos, que antes nos orgulhavam, estão retrocedendo á sua má posição e desarmonia originais..." (CASE $\left.{ }^{27}, 1920\right)$

\subsubsection{1 - Apinhamento pós-contenção em tratamentos com e sem extrações no arco inferior}

Os resultados mostraram que nas amostras estudadas, não houve diferença estatisticamente significante para a recidiva do apinhamento ântero-inferior nos casos tratados com extração de apenas dois pré-molares superiores (grupo1) e o grupo tratado com a extração de dois pré-molares superiores e dois pré-molares inferiores, acompanhados por um período médio de 5 anos após o tratamento (Tabela 2 e 3). Estes achados corroboram os achados da literatura ${ }^{6,14,17,76,89}$,que comparam grupos portadores de má oclusão de Classe II, divisão 1, tratados com extração de 
quatro pré-molares e sem extrações de pré-molares, e concluem que as extrações no arco inferior não alteram de modo significativo a direção das mudanças póstratamento, principalmente alterações relativas ao alinhamento dos incisivos inferiores.

O fato das amostras tratadas com a extração de dois e quatro prémolares mostrarem quantidades médias de apinhamento inicial com diferenças estatisticamente significantes (grupo $1: 3,23$ milímetros e grupo $2: 5,25$ milímetros), poderia gerar dúvidas com relação aos resultados, já que a quantidade de apinhamento inicial, segundo alguns autores ${ }^{45,129}$, tem influencia no comportamento a longo prazo desta variável. Em outras palavras, para estes autores ${ }^{45,129}$, a severidade das mudanças pós-contenção parecer ter alguma relação com a severidade da má oclusão inicial. Desta forma, realizoutse a eliminação de 16 pacientes do grupo 2, os quais apresentavam os maiores apinhamentos antes do início do tratamento, e assim obteve-se o subgrupo 2 com apinhamentos iniciais e desvios padrões mais compatíveis com o grupo 1 , permitindo que as duas modalidades de tratamento fossem comparadas a partir de uma paridade inicial desta variável (apinhamento inferior inicial do grupo 1: 3,23 milímetros e do subgrupo 2: 3,06 milímetros).

Esta semelhança no comportamento pós-contenção para a recidiva do apinhamento ântero-inferior ocorreu da mesma forma do que quando se consideram todos os pacientes da amostra, e assim não houve diferença estatisticamente significante para a recidiva do apinhamento ântero-inferior nos casos tratados com extração de apenas dois pré-molares superiores (grupo1) e o 
subgrupo 2, tratado com a extração de dois pré-molares superiores e dois pré-molares inferiores (tabelas 4 e 5).

Trabalhos da Universidade de Illinois ${ }^{95,105,129}$ são mais otimistas com relação à recidiva, quando comparados com este estudo, pois a maioria das correções foi mantida, muito embora haja concordância com a similaridade do comportamento pós-contenção das amostras tratadas com e sem extrações de prémolares. Para UHDE, et $\mathrm{al}^{128}$, há pequenas diferenças com relação à recidiva do apinhamento ântero-inferior encontradas entre os grupos com extração $(1,27$ milímetros) e sem extração (1,11 milímetros) no arco inferior, e estas recidivas não alcançam os níveis do apinhamento original, quando avaliadas em um período de 12 a 35 anos (média de 20 anos). As amostras abordadas apresentam uma maior recidiva do apinhamento inferior, tanto para o grupo 1 (2,21 milímetros) como para o grupo 2 (2,11 milímetros), embora o tempo de controle pós-contenção seja menor que os estudos de de UHDE,et $\mathrm{al}^{129}$, SADOWSKI, et $\mathrm{al}^{95}$ e PUNEKI, et $\mathrm{al}^{105}$, o que faz crer, baseando-se nos achados de LITTLE, et $\mathrm{al}^{68,72}$, que os valores relativos a recidiva nos dois grupos deste trabalho, tenderão a aumentar com o aumento do período de acompanhamento pós-contenção, chegando a valores próximos ao do apinhamento inicial.

A semelhança do comportamento pós-contenção da amostra tratada com e sem extrações no arco inferior, não é sustentada pelos resultados obtidos por de KAHL-NIEKE, et $\mathrm{a}^{57,58}$, em 1995 , que encontrou maior recidiva no grupo tratado sem extrações (2,3 milímetros) do que no grupo tratado com extrações $(1,8$ milímetros), após 15,7 anos de acompanhamento pós-contenção. Talvez, esta 
diferença maior do índice de Little para os dois grupos, tenha ocorrido em função do tempo de proservação pós-contenção, que tem 10 anos a mais do que este estudo, tempo este no qual poderiam vir à tona diferenças entre os grupos.

Cabe ressaltar que não se encontrou nenhum trabalho na literatura, que compare casos de Classe II tratados com extrações de dois e quatro pré-molares, e assim, utilizourse para esta discussão, somente artigos que comparam e estabilidade do tratamento da má oclusão de Classe II, abordada com e sem a extração de prémolares.

\subsubsection{2 - Apinhamento pós-contenção em tratamentos com extrações no arco inferior}

“ a irregularidade de incisivos na maioria das vezes se desenvolve após a contenção, principalmente no arco inferior." (LITTLE et $\mathrm{al}^{62}$; LOMBARDI ${ }^{74}$; SADOWSKI et $\mathrm{al}^{105}$, REITAN $^{96}$, THILANDER $\left.^{124}\right)$.

Esta afirmação confirmou-se na amostra de 47 pacientes Classe II tratados com extração no arco inferior, na qual o apinhamento inicial de 5,25 milímetros (índice de Little), recidivou para 2,11 milímetros ao final de 5 anos póstratamento (tabela 2). Esta recidiva na direção do apinhamento inicial é um fenômeno marcante encontrado na literatura, sendo que quanto maior o tempo de acompanhamento pós-contenção, mais próximo dos valores iniciais de apinhamento está a recidiva $49,72,61,80,84,89,95,131$. Esta tendência foi também encontrada por ARTUN, et al $^{6}$ e ROSSOUW et $\mathrm{al}^{102}$, sendo que, apesar dos autores terem formado as 
amostras em questão, com pacientes que ao final do tratamento ortodôntico apresentavam oclusões ideais, mesmo assim, não encontraram boa estabilidade a longo prazo no alinhamento ântero-inferior. Ressalte-se, que nos critérios de seleção da amostra tratada com quatro extrações de pré-molares neste estudo, não foi utilizado o quesito de qualidade de finalização ortodôntica. Muitos do 47 casos tratados com extração de quatro pré-molares, foram utilizados por BRAMBILLA ${ }^{22}$, que concluiu que a qualidade de finalização de casos de Classe II tratados com a extração de quatro pré-molares é inferior àqueles tratados com a extração de dois pré-molares.

Em alguns casos, o valor do índice de irregularidade póscontenção, supera a irregularidade inicial da má oclusão, como nos casos de extração seriada avaliados 10 anos pós-contenção por LITTLE, et al ${ }^{68}$, sendo que neste artigo, o autor refuta a abordagem precoce do apinhamento ântero-inferior, através dos procedimentos de extração seriada, como método para se aumentar a estabilidade das correções. Recidivas semelhantes foram encontradas nas amostras tratadas com extração de pré-molares nos estudos ${ }^{1,26}$.

Comparando-se planejamentos que combinam diferentes padrões de extrações no arco inferior para a correção do apinhamento inferior, a extração de um incisivo ou de dois incisivos, seria segundo Riedel, et $\mathrm{al}^{100}$, a escolha que proporciona a maior estabilidade pós-contenção, principalmente quando comparada com a extração de primeiros e segundos pré-molares ${ }^{67,72,80}$. Deve ser lembrado, que para a seleção da amostra utilizada neste trabalho de má oclusão de Classe II tratada 
com a extração de quatro pré-molares, não se fez distinção entre pacientes que tiveram seus primeiros ou segundos pré molares inferiores extraídos.

A amostra do estudo VADEN et $\mathrm{al}^{131}$, apresenta similaridade à deste estudo, com relação ao apinhamento inicial, e como também a quantidade de recidiva do apinhamento de incisivos é semelhante (tabelas 2 e 3). Esta comparação demonstra que se o tempo de acompanhamento pós-contenção desta amostra for aumentado, espera-se um aumento quantitativo no índice de irregularidade de incisivos, corroborando os achados de LITTLE et $\mathrm{al}^{72}$.

Em alguns trabalhos, o valor da recidiva do apinhamento inferior é clinicamente insignificante, ou seja, representam irregularidade dos incisivos inferiores, abaixo de 3,5 milímetros ${ }^{66}$, mostrando um otimismo dos autores com relação à recidiva ${ }^{14,20,21,76,82,90,102,105,129}$. Em alguns destes trabalhos ${ }^{14,20,21,90,105}$, foram utilizadas técnicas de fibrotomias circunferenciais e de desgaste interproximal, o que pode ter levado à esta maior estabilidade melhores resultados. $\mathrm{O}$ trabalho mais otimista com relação à recidiva, é o de $\mathrm{BOESE}^{20,21}$, que mostra uma recidiva do apinhamento de 0,62 milímetros, num período de 9 anos pós-contenção.

$\mathrm{Na}$ amostra deste trabalho que foi tratada com extrações de quatro pré-molares, não foi executado nenhum dos procedimentos supracitados.

Estes trabalhos estão aqui qualificados como otimistas $^{14,20,21,76,82,90,102,105,129}$, pois em alguns deles a recidiva relatada esteve abaixo das alterações decorrentes do processo normal de crescimento e desenvolvimento crânio-facial esperado, que corresponde a um aumento no apinhamento que normalmente ocorre durante a adolescência e idade adulta precoce para os indivíduos 
normais não tratados ${ }^{19,26,75,115}$. Para HIXON; HOROWITZ ${ }^{52}$, o tratamento ortodôntico pode alterar o curso das contínuas mudanças fisiológicas e possivelmente, por um tempo, mesmo revertê-las. No entanto, na seqüência ao tratamento ativo e o período de contenção, o processo de desenvolvimento e maturação da oclusão é retomado, levando inclusive a um aumento na irregularidade dos incisivos inferiores.

Comparando-se os resultados desta amostra com extrações (grupo 2) com os de LITTLE, et $\mathrm{al}^{67,72}$, que estudaram casos com extrações de 4 primeiros pré-molares, nota-se uma menor recidiva quando se avalia o apinhamento póscontenção (tabela 2). Isto pode ser devido à quantidade de apinhamento inicial ser menor neste trabalho do que na amostra estudada pelos autores ${ }^{67,72}$, e o período de acompanhamento pós-tratamento ser somente de 5 anos, enquanto os autores seguiram seus pacientes por períodos de dez a vinte anos.

\subsubsection{3 - Apinhamento pós-contenção em tratamentos sem extrações no arco inferior}

A literatura em geral, mostra a mesma tendência encontrada nesta amostra de 19 pacientes Classe II, tratados sem extração no arco inferior, na qual o apinhamento inicial de 3,77 milímetros (índice de Little), recidivou para 2,39 milímetros ao final de 5 anos pós-tratamento (tabela 2 e 3). Esta recidiva na direção do apinhamento inicial é um fenômeno marcante, sendo que quanto maior o tempo de acompanhamento pós-contenção, mais próximo dos valores iniciais de apinhamento está a recidiva $\cdot 45,89,129,134,135$. 
Em algumas amostras encontradas na literatura, o valor do índice de irregularidade pós-contenção supera a irregularidade inicial da má oclusão, como nos casos tratados sem extração, e que apresentavam diastemas ao início do tratamento, avaliados 14,3 anos pós-contenção por LITTLE, et a $6^{68}$. Situação encontrada por ARTUN et $\mathrm{al}^{6}$, CARTER et $\mathrm{al}^{26}$, LUPPANAPORNLARP et $\mathrm{al}^{76} \mathrm{e}$ LITTLE, et $\mathrm{al}^{69}$.

SADOWSKI, et $\mathrm{al}^{106}$, encontrou um alinhamento dos incisivos inferiores na fase de pós-contenção que julgou relativamente bom (recidiva mínima), e creditou este resultado ao tempo de contenção aumentado, que foi em média de 8 anos de contenção. A contenção prolongada, durante todo o período de crescimento da adolescência seria, segundo os autores ${ }^{19,26,75,115}$ vantajosa, pois os incisivos tendem a apinhar durante este período, mesmo se não receberam tratamento ortodôntico. Saliente-se que a amostra de Classe II tratada com a extração de dois pré-molares superiores, utilizou contenção fixa colada de canino a canino inferior, por um tempo médio de dois anos pós-tratamento ativo, e portanto segundo SADOWSKI et al ${ }^{106}$, este tempo de contenção deveria ser aumentado, para que fosse obtido uma melhoria nos índices de estabilidade.

Os resultados da amostra sem extrações no arco inferior (grupo 1), são similares a GLENN, et $\mathrm{al}^{45}$, quando se avalia a melhora do apinhamento global (tabela 3 e 5), diferentemente de $\mathrm{KAPLAN}^{59}$, que mostrou um grupo tratado sem extrações com apinhamento pós-contenção maior do que o apinhamento visto ao início do tratamento. 
Os resultados mais otimistas encontrados na literatura para pacientes Classe II tratados sem extração são os de DUGONI, et $\mathrm{al}^{34}$, nos quais um apinhamento inicial de 7,81 milímetros foi corrigido com a utilização do espaço livre de Nance ("Leeway Space"), com desgastes interproximais e cirurgia periodontal (fibrotomia circunferencial supracristal). Houve uma recidiva de 2,65 milímetros após 5 anos de período de pós-contenção. BISHARA, et al $^{19}$, relata recidiva para apenas 1,3 milímetros, mas deve-se considerar que, o período de dois anos póscontenção utilizado em seu trabalho, é muito curto.

Para LITTLE, et $\mathrm{al}^{72}$, a contenção permanente, ou no mínimo o uso periódico de contenção removível, talvez por toda a vida, continua a ser o método sugerido para evitar a recidiva. Os pacientes e seus pais precisão entender as nossas limitações e os seus papéis na manutenção dos resultados do tratamento. Os autores afirmam ainda que os pacientes passam por um processo fisiológico de constrição do arco, e aumento do apinhamento inferior, e somente por meios de contenção artificial pode-se garantir o sucesso pós-tratamento.

\subsection{3 - Alterações da Largura intercaninos durante e após o tratamento Ortodôntico}

“...a largura intercaninos deveria permanecer inviolável." (STRANG $^{119}, 1932$; SHAPIRO ${ }^{108}, 1974$ McCAULEY $^{77}, 1944$; EL-MANGOURY ${ }^{36}$, 1979 ; JOHNSON ${ }^{56}$, 1977; BOESE ${ }^{20,21}, 1980$; GARDNER; CHACONAS ${ }^{42}, 1976$; GLENN $^{45}, 1987$; STEADMAN ${ }^{118}, 1961$; UHDE $\left.^{129}, 1983\right)$ 
“A distância intercaninos não deve ser alterada, e a largura intercaninos inferior deve ser usada como referência, em torno da qual devemos construir o arco maxilar." (McCAULEY ${ }^{76}, 1944$ )

"largura intercaninos inferior é um guia infalível para o equilíbrio muscular que dita a expansão nesta área”. $\left(\mathrm{STRANG}^{119}, 1932\right)$

\subsubsection{1 - Alterações da largura intercaninos inferior em tratamentos com e sem extrações}

Analisando-se os resultados obtidos, verificou-se uma diferença estatisticamente significante entre os grupos tratados com a extração de apenas dois pré-molares superiores (grupo1), e o grupo tratado com a extração de quatro prémolares (grupo 2), com relação ao comportamento para a distância intercaninos durante a terapia ortodôntica, com uma diminuição desta dimensão no grupo 1 (-0,27 milímetros), e um aumento na amostra tratada com extração (1,87 milímetros), como mostra a tabela 5.3 e 5.5. Isso demonstra que precauções foram tomadas no grupo sem extrações no arco inferior, no sentido de se evitar durante o tratamento, a expansão transversal dos caninos, visto que neste grupo, dez dos dezenove pacientes, foram submetidos à desgaste interproximal na região de incisivos inferiores, para acomodar o apinhamento ântero-inferior prévio ao tratamento. Já o aumento na largura intercaninos para o grupo 2, é explicado pelo posicionamento distal dos caninos inferiores, ocupando o espaço da extração e consequentemente aumentando esta dimensão do $\operatorname{arco~inferior~}^{119}$. 
Porém estas alterações distintas para os dois grupos que são observadas durante o tratamento, não refletiram em comportamentos distintos para a distância intercaninos entre os dois grupos, no período pós-contenção (Tabelas 3 e 5). Em outras palavras, a largura intercaninos não mostrou diferença estatisticamente significante entre os grupos, quando se considerou o período pós-contenção, sendo que esta variável diminuiu no grupo 1 (-0,69 milímetros) e no grupo 2 (-0,95 milímetros), confirmando os achados na literatura da tendência de constrição desta medida na fase de pós-contenção, perdendo-se a expansão ganha durante o tratamento, como resultado da recidiva dos caninos em direção à sua posição original, independente se o tratamento foi executado com ou sem extrações de prémolares no arco inferior ${ }^{72,91,108,129}$. GARDNER; CHACONAS ${ }^{42}$, encontraram uma maior constrição pós-contenção na largura intercaninos para o grupo tratado com extrações.

LITTLE, et al $^{72}$, afirma que esta constrição da largura intercaninos é progressiva, principalmente na primeira década pós-tratamento. Na Segunda década pós-contenção, segundo os autores ${ }^{72}$, a constrição continua, porém em menor grau.

Como visto na tabela 3 , quando se considera todo o intervalo de tempo avaliado, ou seja, do início do tratamento até o período de pós-contenção, o grupo 1 mostrou uma tendência de maior constrição da distância intercaninos (0,96milímetros), quando comparado com o grupo 2 (-0,3 milímetros), embora esta diferença não tenha sido estatisticamente significante. A mesma tendência se nota, 
quando se compara as alterações da distância intercaninos na pós-contenção para o grupo 1 e o subgrupo 2 (tabela 4 e 5 ).

\title{
6.4.3.2 - Alterações da largura intercaninos inferior em tratamentos com extrações no arco inferior
}

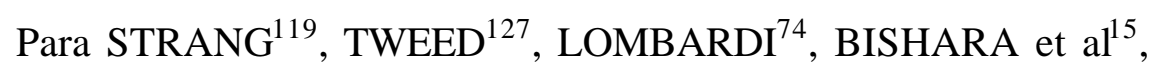
os casos tratados com extrações normalmente apresentam expansão da distância intercaninos, de forma que os caninos são distalizados para os espaços das extrações, ocupando assim regiões mais largas da arcada dentária, e somente assim, lançando-se mão das extrações, esta expansão das distância intercaninos seria estável.
\end{abstract}

Nesta amostra tratada com extrações no arco inferior, a distância intercaninos mostrou um aumento médio durante o tratamento (0,92 milímetros), aumento este corroborado em toda literatura compulsada ${ }^{40,67,72,131}$. Na pós-contenção esta variável decresceu na amostra estudada (-0,95 milímetros), corroborando a literatura, que mostra diminuições similares, que progressivamente aumentam com o aumento do intervalo de observação pós-contenção ${ }^{40,62,72,131}$.

Alguns artigos mostram casos tratados com extração no arco inferior, nos quais a constrição pós-contenção da distância intercaninos, leva a valores menores do que os valores iniciais da má oclusão ${ }^{6,25,40,49,84,125,129}$. Observa-se que esta amostra com extrações no arco inferior (grupo 2), apresenta resultados das alterações durante o tratamento e pós-contenção para a distância intercaninos 
similares aos estudos de $\mathrm{BOESE}^{20,21}$, que também mostra valores pós-contenção inferiores ao valor da distância intercaninos original.

Outros artigos mostram, a manutenção da expansão conseguida durante o período de tratamento na distância intercaninos, embora haja diminuição desta variável na fase de pós-contenção ${ }^{15,42,76,82,89,116}$. SONDHI et al $^{116}$, ainda concluiram que o movimento distal dos caninos, não assegurou um aumento estável das largura.

Somente o artigo de BISHARA; CUMMINS; ZAHER ${ }^{14}$, mostrou diminuição da largura intercaninos em casos tratados com a extração de pré-molares durante o tratamento, da ordem de 1,35 milímetros, e que continuou a decrescer na fase de pós-contenção (0,7 milímetros).

Com relação ao tipo de má oclusão, vários autores têm afirmado que a expansão intercaninos pode ser bem tolerada na Classe II divisão 2 com extrações ${ }^{108}$, mais do que em casos de pacientes Classe I. Achado não corroborado por UHDE, et $\mathrm{al}^{129}$, quando estes compararam pacientes Classe I e Classe II, não notaram diferença com relação à estabilidade para a expansão da distância intercaninos.

\subsubsection{3 - Alterações da largura intercaninos inferior em tratamentos sem extrações}

“A expansão lateral do arco inferior, comumente falha, e o arco dentário tipicamente retorna ao tamanho e forma pré-tratamento, e assim deveria-se 
usar a forma do arco pré-tratamento como um guia para a forma do arco." (LITTLE et $\left.\mathrm{al}^{70}, 1990\right)$

“a expansão excessiva deveria ser evitada, em especial se a discrepância entre o tamanho dentário e do arco existir, desta forma esta seria uma indicação para se reduzir o número de dentes." (NANCE $\left.{ }^{85}, 1947\right)$

Já, STEADMAN ${ }^{118}$, WALTER $^{133}$, HERBERGER $^{51}$, acreditam que um aumento moderado na largura intercaninos poderia ser tolerada e mantida, se houvesse um equilíbrio com a função muscular e o crescimento do paciente, muito embora o próprio STEADMAN ${ }^{118}$ tenha sugerido que se evitassem expansões com o tratamento, para se evitar recidivas.

A corrente ideológica que advoga a não expansão da distância intercaninos inferior, tem mencionado exceções potenciais à suas regras, mais notavelmente, vários autores tem afirmado que a expansão intercaninos pode ser bem tolerada na Classe II ${ }^{113}$, Classe II divisão $2^{108}$, mais do que em casos de pacientes Classe I. Para LITTLE, et al ${ }^{67}$, não há diferença estatisticamente significante, no comportamento a longo prazo, da distância intercaninos nos diferentes grupos de má oclusão.

Embora o grupo 1 tenha sido tratado com esforços para manter a distância intercaninos, sem que esta fosse expandida durante o tratamento, pela utilização de desgaste interproximal (tabela 2 e 3), há uma tendência pós-tratamento de constrição desta distância, achados que são coincidentes com os de LITTLE, et $\mathrm{al}^{67}$. No grupo tratado sem extrações no arco inferior, houve uma pequena constrição da largura intercaninos durante o tratamento $(-0,27$ milímetros $)$, medida esta que 
continuou a decrescer no período pós-contenção (-0,69 milímetros). Assim a manutenção da largura intercaninos inicial, não é garantia de estabilidade póscontenção (tabelas 2,3,4,5).

LITTLE, et $\mathrm{al}^{67,72}$; SINCLAIR, et $\mathrm{al}^{115}$ afirmam que há um processo de constrição tardia dos arcos dentários, em pacientes tratados e não tratados, que deve ser considerado como fazendo parte das mudanças normais de desenvolvimento. Porém em pacientes tratados, dois componentes devem ser considerados: o processo fisiológico de maturação, e as mudanças reativas (recidiva) propriamente ditas. Assim, para a distância intercaninos, a taxa de diminuição é três vezes mais rápida no grupo tratado, do que em pacientes normais não tratados ${ }^{115}$.

Por outro lado outros autores, mostram uma tendência de se expandir a distância intercaninos inferior, quando se aborda o apinhamento inferior sem lançar mão de extrações ${ }^{6,14,34,42,45,76,89,106,129,134,135 .}$ Esta tendência de expansão se mostra maior, nos casos com apinhamento maior.

A diminuição da largura intercaninos pós-contenção é um achado comum na literatura, sendo que esta variação é maior nos casos mais expandidos durante o tratamento, e também nos casos com maior acompanhamento cronológico pós-contenção. A constrição da distância intercaninos nesta amostra é compatível com os trabalhos de JOHNSON JÚNIOR ${ }^{56}$, WILLIAMS, et al ${ }^{135}$ e GARDNER; CHACONAS $^{43}$. Casos que experimentaram mais expansão durante o tratamento, acabaram por ter constrições superiores a 1 milímetro na fase de pós-contenção ${ }^{6,14,26 \text {, }}$ 34,45,76,89,106, 129,134, chegando a valores próximos aos da largura intercaninos inicial. 
Para VADEN et $\mathrm{al}^{131}$, pacientes que tiveram as maiores diminuições nas larguras do arco após o tratamento, também tenderam a experimentar os maiores aumentos no apinhamento ântero-inferior. As alterações na larguras intercaninos inferior foram significativamente correlacionadas com o aumento na irregularidade dos incisivos inferiores.

Já SANDSTROM, et $\mathrm{al}^{107}$, mostraram a manutenção de uma expansão de 1,1 milímetros na distância intercaninos inferior, sendo que os autores afirmam que esta manutenção foi possível devido à expansão simultânea do arco superior. WALTER ${ }^{133}$, concluiu que a afirmação de que o arco dentário não pode ser permanentemente alongado ou alargado é incorreta. LOMBARDI ${ }^{74}$ e PEAK $^{91}$ sustentam que quanto mais se expande o arco inferior mais apinhados os casos se tornam após o tratamento.

\subsection{4 - Alterações da Largura intermolares durante e após o tratamento Ortodôntico}

“... a largura intermolar é uma dimensão que não deveria ser alterada de seu tamanho original." (STRANG $\left.{ }^{19}, 1932 ; \operatorname{McCAULEY}^{77}, 1944\right)$.

"um aumento na largura intermolar poderia ser tolerado se moderado e em equilíbrio com a função muscular e o crescimento." (STEADMAN $^{118}, 1961$; WALTER $\left.{ }^{133}, 1953\right)$. 


\subsubsection{1 - Alterações da Largura intermolares em tratamentos com e sem extrações no arco inferior}

Os resultados mostram que durante o tratamento houve uma diminuição da distância intermolar para os dois grupos, sendo de 0,68 milímetros para o grupo 1, e de 2,15 milímetros para o grupo 2, mostrando uma diminuição significativamente maior do ponto de vista estatístico, no grupo com quatro extrações de pré-molares (tabelas 2,3,4,5). Isto se deve a mesialização dos molares para regiões mais estreitas do arco dentário, durante o fechamento dos espaços das extrações inferiores no grupo 2 .

No entanto durante a fase de pós-contenção, houve um pequeno aumento na largura intermolar, sendo que este aumento se mostrou similar para os dois grupos. Esta semelhança de comportamento dos grupos tratados com e sem extrações no arco inferior na fase de pós-contenção, para a largura intermolares também foi um achado de outros trabalhos ${ }^{42,108,129}$, embora estes trabalhos mostrem uma diminuição desta dimensão no período pós-contenção. UHDE et $\mathrm{al}^{129}$, relacionaram esta diminuição pós-contenção da distância intermolares, com o aumento desta distância durante o tratamento.

Alguns artigos mostram comportamento diferente quando se comparam casos tratados com e sem extrações, e quando se leva em conta a estabilidade a longo prazo da largura intermolar ${ }^{20,21,108,133}$. Nos casos com extrações, a distância intermolar diminui durante o tratamento e continua a decrescer na póscontenção; nos casos sem extrações, houve um uma manutenção desta distância 
durante o tratamento e em alguns casos aumento na distância intermolar na fase de pós-contenção ${ }^{20,21,108,133}$.

Para UHDE, et $\mathrm{al}^{129}$, as poucas mudanças que foram observadas durante e após o tratamento, tendem a sustentar o conceito da estabilidade da distância intermolar, em especial nos casos de Classe II, os quais mantiveram pequenos aumentos na largura intermolar, no período pós-contenção ${ }^{133}$.

\subsubsection{2 - Alterações da Largura intermolares em tratamentos com extrações no arco inferior}

Durante o tratamento houve uma diminuição da distância intermolar (-2,15 milímetros), que se deve à mesialização dos molares para regiões mais estreitas do arco dentário, durante o fechamento dos espaços das extrações $^{6,26,40,42,76,80,84,89,91108,131}$ (tabela 2 e 3).

No entanto nesta amostra, há durante a fase de pós-contenção, um pequeno aumento na largura intermolar ( 0,11 milímetros) para o grupo 2 . Este resultado contraria os autores $6,40,80,91,108,129,131$, que mostram uma diminuição póscontenção da distância intermolar. $\mathrm{CARTER}^{26}$ et al, demostraram que a largura intermolar tendem a diminuir durante o período de pós-contenção, sendo esta constrição diretamente proporcional ao tempo de controle pós-contenção. Outros autores, como este trabalho, mostram um aumento ou manutenção pós-contenção da distância intermolares na pós-contenção ${ }^{14,42,76,84,89}$, aumento este não compatível com 
a constrição da distância intermolares, mostradas nos pacientes normais não $\operatorname{tratados}^{26,75,115}$.

\subsubsection{3 - Alterações da Largura intermolares em tratamentos sem extrações no arco inferior}

Durante o tratamento houve uma pequena diminuição da distância intermolares para o grupo 1 (-0,68 milímetros). Estes achados são corroborados pela literatura ${ }^{26,76}$. Porém, no geral, os trabalhos com amostras sem extração 6,14,34,42,45,89,106,114,135, mostram um aumento da distância intermolares durante o tratamento, expansão transversal que é executada com o intuito de prover espaço para o alinhamento dos dentes apinhados.

No entanto durante a fase de pós-contenção, há um pequeno aumento na largura intermolar (0,12 milímetros), o que concorda com os autores que mostram uma tendência de manutenção ou aumento da distância intermolares na póscontenção ${ }^{34,42,76,89}$. Embora tenha-se este pequeno aumento na distância intermolares, sabe-se que a tendência, em estudos de indivíduos normais não tratados é de que haja uma diminuição tênue nesta ${ }^{14,26,115}$. Também há esta tendência, em amostras tratadas sem extração no arco inferior, em que esta distância foi aumentada durante o tratamento $^{91,108}$, de forma que largura intermolar tende a retornar a suas dimensões pré-tratamento, principalmente se foi expandida durante a terapia.

Esta diminuição pós-contenção da distância intermolar, aumenta com o aumento do tempo de proservação pós-contenção $6,14,26,45,106,108,129,133,135$. 
Para VADEN et $\mathrm{al}^{131}$, as avaliações da recidiva na largura intermolares são confundidas com estas alterações normais mediadas pelo envelhecimento. As larguras do arco também diminuem com a idade, e isto também faz parte do processo de envelhecimento, que está documentado nas amostras de pacientes tratados e não tratados. Para o autor ${ }^{131}$, as reduções parecem ser devidas a migração mesial dos dentes. A documentação do componente anterior de forcas durante a mordida e outras funções orais ${ }^{117}$, sugere a provável causa da mesializacão.

Ainda para VADEN, et $\mathrm{al}^{131}$, pacientes que tiveram as maiores diminuições nas larguras do arco após o tratamento também tenderam a experimentar os maiores aumentos no apinhamento ântero-inferior.

\subsection{5 - Alterações do comprimento do arco durante e após o tratamento Ortodôntico}

\subsubsection{1 - Alterações do comprimento do arco em tratamentos com em sem extrações no arco inferior}

As diferenças no comprimento do arco, nos grupos com e sem extrações durante o tratamento, são facilmente explicadas, segundo SHAPIRO ${ }^{108}$. Se dentes são extraídos, se espera que o comprimento do arco diminua de forma significativa. $\mathrm{Na}$ amostra com quatro extrações (grupo 2), houve uma diminuição de 8,45 milímetros, e na amostra extrações de apenas dois pré-molares (grupo 1), houve uma manutenção do comprimento do arco durante o tratamento(tabelas 2 e 3). 
Na pós-contenção os dois grupos não mostraram diferenças na diminuição do comprimento do arco, corroborando os achados de LITTLE et $\mathrm{al}^{72} \mathrm{e}$ GARDNER; CHACONAS ${ }^{42}$ que afirmam: "um fator que se mostra consistentemente previsível, é a diminuição contínua do comprimento do arco mandibular, que ocorre com o tempo, na seqüência a remoção das contenções”. Para o grupo 1 a diminuição pós-contenção do comprimento do arco foi de 1,26 milímetros e para o grupo 2 foi de 1,60 milímetros, diferença esta que, não apresenta relevância do ponto de vista estatístico (tabelas 2 e 3).Esta similaridade foi também evidente quando se comparou o grupo 1 e o subgrupo 2 (tabelas 4 e 5).

Desta forma, as reduções do comprimento de arco encontradas neste trabalho, são um pouco menores do que os estudos de pacientes normais não $\operatorname{tratados}^{115}\left(-2,0\right.$ milímetros) e casos com extrações 10 anos sem contenção ${ }^{67,72}(-2,5$ milímetros), porém deve ser considerado, que o tempo pós-contenção da amostras de Classe II ,tratadas com a extração de dois e quatro pré-molares , é a metade do que os trabalhos referidos, e portanto com o aumento do tempo de controle destas amostras, se espera uma perda ainda maior no comprimento do arco, principalmente como reflexo do processo de maturação oclusal, que atua sobre o comprimento de $\operatorname{arco}^{115}$.

Com relação à influência do tratamento ortodôntico sobre a maturação facial e oclusal, HIXON; HOROWITZ ${ }^{52}$ afirmaram: "o tratamento ortodôntico pode alterar o curso das contínuas mudanças fisiológicas e possivelmente, por um tempo, mesmo revertê-las. No entanto, na seqüência ao tratamento ativo e o período de contenção, o processo de desenvolvimento e a maturação é retomado". 


\subsubsection{2 - Alterações do comprimento do arco em tratamentos com extrações no arco inferior}

A maioria dos autores $6,40,42,49,67,76,80,84,89,102,131$, afirmam que o comprimento do arco inferior durante o tratamento, diminuiu em função das extrações. Neste trabalho encontrou-se uma diminuição média de 8,45 milímetros no comprimento do arco durante o tratamento, na amostra tratada com extrações no arco inferior (tabelas 2 e 3 ).

Na pós-contenção desta amostra, houve uma contínua diminuição no comprimento do arco da ordem de 1,60 milímetros, para o período médio de 5,91 anos de controle pós-tratamento. Na literatura, observa-se este comportamento em amostras com extrações, e a diminuição no comprimento de arco é tanto maior quanto maior é o tempo de controle pós-contenção $6,40,42,49,67,76,80,84,89,102,131$.

Para LITTLE et $\mathrm{al}^{67}$, houve uma correlação fraca entre o grau de redução do comprimento do arco pós-contenção, e a severidade do apinhamento póscontenção, com apenas $27 \%$ do apinhamento sendo explicado pela diminuição no comprimento do arco.

\subsubsection{3 - Alterações do comprimento do arco em tratamentos sem extrações no arco inferior}

Este trabalho, assim como em outros ${ }^{6,34,42,45,76,129,133}$, que utilizam amostra de casos tratados sem extração no arco inferior, mostrou alterações mínimas do ponto de vista estatístico durante o tratamento para o comprimento do arco. Isto ocorreu possivelmente em função do desgaste interproximal realizado em alguns 
pacientes (10 dos 19 pacientes do grupo 1), de forma que não se permitiu um aumento no comprimento do arco, pela projeção para vestibular dos incisivos inferiores.

Estes resultados diferem das amostras com apinhamento tratadas sem extrações, nas quais há um aumento do comprimento do arco durante o tratamento $^{89,106,134}$. Para ROSSOUW, et $\mathrm{al}^{102}$, o aumento do comprimento do arco durante o tratamento com vestibularização de incisivos pode ser um fator que contribui para a recidiva do apinhamento inferior, principalmente quando há um movimento anterior, além dos limites da estabilidade durante o tratamento, ou por causa da componente anterior de força, após a remoção do aparelho (incisivos superiores e o músculo orbicular do lábio, não permitem que os incisivos inferiores permaneçam inclinados para vestibular). LITOWITZ, et al ${ }^{67}$, afirma que incisivos que foram vestibularizados, tendem a retornar a sua angulação original de antes do tratamento.

MILLS $^{81}$, indica a vestibularização de incisivos inferior em casos de pacientes com sucção digital, que tinham os dentes lingualizados pelo hábito, e uma vez que este hábito foi removido, os incisivos voltam a inclinação normal. Casos de Classe II divisão 1, com interposição do lábio inferior que forçam uma posição lingualizada dos incisivos inferiores, e da mesma forma quando removido o hábito, os incisivos voltam a sua inclinação normal. Casos com Classe II divisão 2 onde os incisivos inferiores estão lingualizados pelo cíngulo dos incisivos superiores, o que é eliminado pela redução da sobremordida. 
Nesta amostra, embora tenha tido esforços para não aumentar o comprimento do arco através da vestibularização dos incisivos, mesmo assim ocorreu uma recidiva do apinhamento ântero-inferior, após 5,17 anos de acompanhamento pós-tratamento (tabelas 2 e 3 ).

Diminuições significativas foram vistas no comprimento do arco (1,26 milímetros), durante a fase de pós-contenção, nesta amostra, o que é também constatado ao se examinar a literatura ${ }^{6,26,34,42,45,76,89,106,129,133,135}$, sendo que esta diminuição pós-contenção é maior nas amostras que foram observadas por maiores períodos . As larguras do arco também diminuem com a idade, e isto também faz parte do processo da maturação da oclusão, que está documentado nas amostras de pacientes tratados e não tratados ${ }^{131 .}$

Desta forma há uma similaridade em natureza e quantidade, para o comportamento pós-contenção do comprimento de arco de pacientes tratados sem extrações no arco inferior, com normais não tratados (-2,0 milímetros) ${ }^{14,26,115}$.

Para VADEN, et $\mathrm{al}^{131}$, as reduções pós-contenções no comprimento do arco, corroboram estudos de amostras tratadas e não tratadas ortodonticamente. As reduções no comprimento do arco parecem ser devidas a migração mesial dos dentes. A documentação da componente anterior de forcas durante a mordida e outras funções orais ${ }^{117}$, sugere a provável causa da mesialização, e conseqüente diminuição do comprimento do arco. 


\subsection{6 - Implicações Clínicas}

Pelos resultados obtidos, não houve evidência de que há uma diferença na recidiva do apinhamento ântero-inferior, em pacientes portadores de má oclusão de Classe II de Angle, tratados com a extração de dois ou quatro prémolares.

De uma forma geral, sabe-se que a realização da extração de somente dois pré-molares superiores está geralmente indicada, quando não há apinhamento ou discrepância cefalométrica no arco dentário inferior ${ }^{13,46,87}$. A utilização da mecânica de extrações de quatro pré-molares na Classe II, está geralmente indicada quando o arco inferior apresenta apinhamento dentário, discrepância cefalométrica ou uma combinação destas características, para os pacientes que ainda se encontram na fase de crescimento ${ }^{7,46}$.

Com base nos resultados obtidos nesse trabalho, essas indicações devem ser revistas. A indicação de extrações de dois pré-molares superiores na Classe II sem apinhamento inferior ou discrepância cefalométrica não parece carecer de uma revisão, pelos resultados obtidos. Entretanto, o mesmo não se aplica para as indicações do protocolo de extrações de quatro pré-molares, principalmente se o problema do arco inferior for apenas um apinhamento leve ou moderado, já que, considerando-se a recidiva do apinhamento inferior, não houve diferença deste tipo de abordagem, para a abordagem com extrações somente de dois pré-molares superiores.

Entende-se que essa tendência existe na Ortodontia desde o desenvolvimento da mecânica com extrações dentárias, por Tweed. O autor 
recomendava que os incisivos inferiores deveriam estar verticalizados na base apical, com a finalidade de proporcionar maior estabilidade nos casos finalizados ${ }^{127,128}$. Tweed também sugeria que os primeiros molares deveriam terminar em uma relação de Classe I, como em uma oclusão normal ${ }^{127,128}$.

Assim a mecânica ortodôntica nesses casos foi utilizada por muito tempo. Entretanto, estudos posteriores demonstraram que a verticalização dos incisivos inferiores na base apical não é garantia de uma maior estabilidade do alinhamento desses dentes ${ }^{67,86}$, e também parece ser a tendência das amostras aqui estudadas. Mais tarde, os ortodontistas também chegaram a um consenso de que se poderia tratar um caso somente com extrações superiores e terminar com os molares em Classe II ${ }^{46,64,104,137}$. O risco de se abordar a classe II com quatro extrações, somente com o intuito de promover a correção cefalométrica, é de um término ortodôntico oclusal insatisfatório, devido à ausência da correção completa da relação de Classe II nos segmentos posteriores, se houver uma má colaboração do paciente em utilizar os reforços de ancoragem extrabucais ${ }^{22}$.

Por outro lado, se o arco dentário inferior apresentar apinhamento, a solução do problema torna-se um pouco mais complicada. Se o apinhamento for leve, uma abordagem sem extrações poderá ser utilizada no arco inferior e o apinhamento ser resolvido com desgaste interproximal $9^{91,108,109,110}$. Outra solução consiste em se realizar uma disjunção palatina no arco superior, associada a uma desinclinação para vestibular dos dentes posteriores inferiores, com finalidade de propiciar o espaço necessário para o correção do apinhamento desse $\operatorname{arco}^{107}$. 
Quando o apinhamento for moderado, a situação torna-se mais difícil. A solução poderá consistir em se empregar o desgaste interproximal $^{91,108,109,110}$ e a disjunção palatina do arco superior associada a uma desinclinação para vestibular dos dentes posteriores inferiores ${ }^{51,107}$, para resolver o problema do apinhamento do arco inferior. Uma solução alternativa para o apinhamento inferior, que pode ser utilizada nas duas situações anteriores, consiste em se causar uma ligeira protrusão dos incisivos inferiores, principalmente se estes se encontram retroposicionados e inclinados para lingual ${ }^{81}$. Nestas situações, acredita-se que haveria estabilidade da posição obtida, pois os dentes teriam sido verticalizados em sua base apical, de acordo com o preconizado ${ }^{78,127,128}$. Contudo, em alguns casos de apinhamento moderado, em que os incisivos não se encontram lingualizados, e sabendo-se do aumento da dificuldade para a correção da discrepância ântero-posterior que seria acarretada pela extração de quatro prémolare ${ }^{22}$, poderia se recorrer a uma protrusão dos incisivos inferiores para a solução do apinhamento ${ }^{45,69,105}$. Essa protrusão somente poderia ser realizada se não produzisse algum efeito desfavorável no perfil mole, como protrusão indesejável, com conseqüente ausência de selamento labial ${ }^{88}$. Uma das principais críticas que esse procedimento geralmente recebe é de que haverá uma grande tendência à recidiva destes dentes pela pressão exercida pelo lábio inferior ${ }^{46,81,104}$. Acontece que o paciente que apresenta uma má oclusão de Classe II, divisão 1, evidencia em geral, uma grande sobressaliência anterior que invariavelmente recebe a interposição do lábio inferior. Nessa situação, é evidente que o lábio inferior está exercendo uma força intensa para lingual nesses dentes e eles tendem a sofrer uma maior retrusão com o tempo, sob ação do hábito ${ }^{81}$. Todavia, quando a má oclusão é devidamente 
corrigida, não haverá uma sobressaliência e o lábio inferior não se interporá entre os incisivos ${ }^{6,81}$ Aliás, em uma oclusão normal, o lábio inferior apoia-se ligeiramente no incisivo superior ${ }^{88}$. Portanto, a força que o lábio inferior exercerá nos incisivos inferiores, para lingual, será até menor do que antes do tratamento. Por esse motivo é que a protrusão dos incisivos inferiores, nessas situações, não estaria predisposta a um maior risco de recidiva. Outras alternativas para se assegurar a estabilidade em casos nos quais os incisivos inferiores foram protruídos, seria a adesão a um protocolo rígido de contenção fixa inferior, o que segundo SADOWSKI, et al ${ }^{106}$, aumenta a estabilidade da correção do apinhamento ântero-inferior em casos sem extrações.

A oportunidade de se realizar uma protrusão dos incisivos inferiores é maior quando se trata de uma má oclusão de Classe II, divisão $2^{30}$. Geralmente nesses casos os incisivos inferiores estão lingualizados e apresentando graus moderados de apinhamento. Além disso, o mento é bem definido e a altura facial ântero-inferior (AFAI) está diminuída. Portanto, a protrusão dos incisivos inferiores ajudará a aliviar o apinhamento inferior, e propiciará um melhor suporte para o lábio inferior, minimizando a possibilidade de diminuir ainda mais a AFAI. Nos casos de Classe II, divisão 2, SALZMANN ${ }^{104}$ alerta ainda que e extração de prémolares no arco inferior pode conduzir a um trauma ósseo, e consequente insucesso no tratamento.

Ressalte-se que no grupo 1 deste trabalho, os pacientes tratados sem extração no arco inferior, tiveram seus apinhamentos suaves (3,23 milímetros), corrigidos com a manutenção da forma do arco, já que tanto a distância intercaninos, 
como a distância intermolares e o comprimento do arco, não se alteraram durante o tratamento, provavelmente resultado dos desgastes interproximais realizados nestes pacientes. Todavia, cinco anos pós-tratamento, notou-se uma constrição no arco inferior, acompanhada de um aumento na irregularidade dos incisivos inferiores , comportamento este idêntico, do ponto de vista estatístico ao dos pacientes que foram tratados com extrações de quatro pré- molares (grupo 2).

Nos casos extremos, em que o apinhamento no arco inferior é acentuado, geralmente não haverá um outro recurso que elimine totalmente esse problema a não ser a extração de dois pré-molares inferiores. Nesse caso, é imprescindível que o paciente esteja ainda em fase de crescimento, e seja um bom colaborador em utilizar os recursos de reforço de ancoragem extrabucais, para que seja possível se corrigir toda a má oclusão satisfatoriamente. Principalmente a discrepância ântero-posterior completa da Classe II. São essas características acentuadas da má oclusão de Classe II, que tornam esse problema no adulto, passível de solução somente com uma combinação ortodôntico-cirúrgica ${ }^{94}$. Alternativamente, com o desenvolvimento dos mini-implantes, pode ser que essa má oclusão possa ser corrigida satisfatoriamente, mesmo em adultos, sem a necessidade do tratamento combinado ortodôntico-cirúrgico ${ }^{29}$.

Esses resultados, e considerações não tem a intenção de sugerir que o tratamento da Classe II não deva, ou não possa ser realizado, com extrações de quatro pré-molares nos pacientes em crescimento, mas sim de alertar para o fato de que as extrações no arco inferior não aumentam a estabilidade da correção do apinhamento inferior, quando se opta por esse protocolo de tratamento. Por outro 
lado, os resultados sugerem e corroboram a tendência contemporânea, de não se realizar extrações com a intenção única de corrigir discrepâncias cefalométricas $^{30,64,67,86,137}$. Primeiramente, porque não se deve procurar encaixar os pacientes dentro de valores considerados como padrões, e secundariamente porque a verticalização dos dentes na base apical não irá garantir uma maior estabilidade dos resultados $30,64,67,86,104,113,137$.

Essa tendência contemporânea, de não se realizar extrações com a intenção primordial de corrigir discrepâncias cefalométricas, parece ter se manifestado na amostra selecionada, porque verificourse que a maior parte dos casos do grupo 2 consistia de pacientes tratados há mais tempo, em comparação aos casos do grupo 1 (Apêndices). Isso demonstra que o Departamento de Ortodontia da FOBUSP segue as tendências atuais da especialidade.

Foi possível observar neste estudo, que os valores obtidos de toda a amostra, revelaram uma tendência à recidiva semelhante dos casos tratados de má oclusão de Classe II tratados com o protocolo de extrações de dois pré-molares superiores, e de quatro pré-molares. Além desta característica, o fato de se extrair pré-molares ou não no arco inferior, não influenciou, nestes pacientes, o comportamento pós-contenção das larguras ou do comprimento do arco, já que as duas modalidades de tratamento mostraram igualdade do ponto de vista estatístico, para as alterações destas variáveis quando este período de tempo (5 anos póstratamento) foi avaliado. 


\subsection{7 - Sugestões para trabalhos futuros}

- Realizar uma comparação cefalométrica entre esses grupos.

- Avaliar amostra com extração de dois pré-molares, com uma irregularidade de incisivos inferiores maior que 3,5 milímetros, já que a amostra abordada neste trabalho (grupo 1) apresentava índice de Little aceitável do ponto de vista clínico (3,23 milímetros).

- Aumentar o tempo de acompanhamento pós-contenção para estas mesmas modalidades de tratamento. 
7-Conclusões 


\section{7 - CONCLUSÕES}

Com base nos resultados apresentados a hipótese nula foi aceita porque:

O índice de Little inferior pós-contenção e a sua alteração passados cinco anos do término do tratamento ativo, bem como as alterações pós-contenção na forma do arco inferior no grupo de Classe II tratado com extrações de dois prémolares superiores, foram semelhantes, do ponto de vista estatístico, aos grupo de Classe II, tratados com extrações de quatro pré-molares. 
Referências Bibliográficas 


\section{REFERÊNCIAS BIBLIOGRÁFICAS*}

AL YAMI, E.A.; KUIJPERS-JAGTMAN, A.M.; VAN'T HOF, M.A. Stability of orthodontic treatment outcome: follow-up until 10 years postretention. Amer. J. Orthodont. Dentofac. Orthop., v.115, n. 3, p.300-4, Mar. 1999.

2 ALEXANDER, R.G.; SINCLAIR, P.M.; GOATES, L.J. Diagnosis and treatment planning for adult nonsurgical patient. Amer. J. Orthodont. Dentofac. Orthop., v.89, n.2, p.95-112, Feb.1986.

3 ANGLE, E.H. Treatment of malocclusion of the teeth. Angle's System, p.479$89 ; 502-5 ; 514-7,1907$.

4 ANGLE, E.H. The latest and best in orthodontic mechanism. Dent. Cosmos, v.70, n.12, p.1143-5, Dec.1928.

5 ARTUN J.; KROGSTAD, O.D.; LITTLE. R.M. Stability of mandibular incisors following excessive proclination: study in adults with surgically treated mandibular prognathism. Angle Orthodont., v.60, n.2, p. 99-106, Summer 1990.

6 ARTUN J.; GAROL, J.D.; LITTLE. R.M. Long-term stability of mandibular incisors following sucessful treatment of class II, division 1, malocclusions. Angle Orthodont., v.66, n.3, p. 229-38, 1996.

\footnotetext{
* Normas recomendadas para uso no âmbito da Universidade de São Paulo, com base no documento "Referências Bibliográficas: exemplos", emanados do Conselho Supervisor do Sistema Integrado de Bibliotecas da USP, em reunião de 20 de setembro de 1990.
} 
7 ARVYSTAS, M.G. Nonextraction treatment of class II, division 1 malocclusions. Amer. J. Orthodont., v.88, n.5, p.380-95, Nov. 1985.

8 BAUMIRIND, S. et al. The decision to extract: part II. Analysis of clinician's stated reasons for extraction. Amer. J. Orthodont. Dentofac. Orthop. v.109, n.4, p.393-402, Apr. 1996.

9 BARROW. D.B.; WHITE, J.R. Developmental changes of the maxillary and mandibular dental arches. Angle Orthodont., v.22, n.1, p.41-6, Jan. 1952.

10 BEGG, P.R. Begg orthodontic theory and technique. 2.ed., Philadelphia, WB Saunders, 1971. 676p.

11 BEGOLE, E.A.; SADOWSKI, C. Methodology for evaluating long-term stability of dental relationships after orthodontic treatment. Semin. Orthodont., v.5, n.3, p.142-50, Sept.1999.

12 BEGOLE, E.A.; FOX, D.L.; SADOWSKY, C. Analysis of change in arch form with premolar expansion. Amer. J. Orthodont. Dentofac. Orthop. v.113, n.3, p.307-15, Mar. 1998.

13 BISHARA, S.E.; CUMMINS, D.M.; JACOBSEN, J.R. The morphologic basis for the extraction decision in class II division 1 malocclusions: a comparative study. Amer. J. Orthodont. Dentofac. Orthop., v.107, n.2, p. 129-35, Feb. 1995.

14 BISHARA S.E.; CUMMINS, D.M.; ZAHER, A.R. Treatment and posttreatment changes in patients with Class II, division 1 malocclusions 
after extraction and nonextraction treatment. Amer. J. Orthodont. Dentofac. Orthop., v.111, n.5, p.18-27, Jan.1997.

15 BISHARA, S.E. et al. Stability of intercanine width,overbite and overjet correction. Amer. J. Orthodont., v.63, n.6, p.588-95, June 1973.

16 BISHARA, S.E. et al. Changes in the maxillary and mandibular tooth size-arch length relationship from early adolescence to early adulthood. Amer. J. Orthodont. Dentofac. Orthop., v.95, n.1, p.46-59, Jan. 1989.

17 BISHARA S.E. et al. Comparison of the dental arch changes in patients with Class II, division 1 malocclusions: extraction vs nonextraction treatments. Angle Orthodont., v.64, n.5, p.351-8, 1994.

18 BISHARA, S.E. et al.. Changes in the dental arches in dentition between 25 and 45 years of age. Angle Orthodont., v.66, n.6, p.417-22, 1996.

19 BISHARA, S.E. et al. Arch width changes from 6 weeks to 45 years of age. Amer. J. Orthodont. Dentofac. Orthop., v.11, n.4, p.401-9, Apr. 1997.

20 BOESE, L.R. Fiberotomy and reaproximation without lower retention, nine years in retrospect: part I. Angle Orthodont., v.50, n.2, p.88-97, Apr. 1980.

21 BOESE, L.R. Fiberotomy and reaproximation without lower retention, nine years in retrospect: part II. Angle Orthodont., v.50, n.3, p.169-78, July 1980. 
22 BRAMBILLA, A.C. Comparação dos resultados oclusais do tratamento da

Classe II realizado com extrações de dois pré-molares, com a terapêutica utilizando as extrações de quatro pré-molares. 2002. /no prelo/

23 BROWN, V.P.; DAUGAARD-JENSEN, I. Changes in the dentition from the early teens to the early twenties. Acta odont. scand., v.9, n.3, p. 177-92, 1951.

24 BRUSOLA, J.C.A. et al. Ortodoncia clinica. Barcelona, Salvat Editores, 1989, 509p.

25 BURKE, S.P. et al.. A meta-analysis of mandibular intercanine width in treatment and postretention. Angle Orthodont., v.68, n.1 , p.53-60, 1997.

26 CARTER, G.A.; McNAMARA JÚNIOR., J.A. Longitudinal dental arch changes in adults. Amer. J. Orthodont. Dentofac. Orthop., v.114, n.1, p.88-99, July 1998.

27 CASE, C. Principles of retention in orthodontia, Amer. J. Orthodont. Oral Surg., p.3-34, Nov.1920.

28 CASE, C. The question of extraction in orthodontia., Amer. J. Orthodont. v.50, n.9, p.660-91, Sept.1920.

29 CELENZA, F.; HOCHMAN, M.N. Absolute Anchorage in orthodontics: direct and indirect implant-assisted modalities. J. clin. Orthodont., v.34, n.7, p.397-402, July 2000 . 
30 CLEALL, J.F.; BEGOLE, E.A. Diagnosis and treatment of class II, division 2 malocclusion. Angle Orthodont., v.52, n.1, p.38-60, Jan.1982.

31 DAHLBERG, G. Statistical methods for medical and biological students. New York, Interscience, 1940.

32 DAINESI, E.A. Comparação entre o tratamento da Classe II subdivisão, com extrações simétricas e assimétricas. 2001./no prelo/

33 DE LA CRUZ A., et al. Long-term changes in arch form after orthodontic treatment and retention. Amer. J. Orthodont. Dentofac. Orthop., v.107, n.5, p. 518-30, May 1995.

34 DUGONI, E.A. et. al. Early mixed dentition treatment: postretention evaluation of stability and relapse. Angle Orthodont.,v.65, n.5, p.311-20, 1995.

35 EDWARDS, J.G. Circumferential supracrestal fiberotomy in alleviating relapse. Amer. J. Orthodont. Dentofac. Orthop., v.93, n.5, p.380-7, May 1988.

36 EL-MANGOURY, N.H. Orthodontic relapse in subjects with varying degrees of anteroposterior and vertical dysplasia. Amer. J. Orthodont., v.75, n.5, p.548-61, May 1979.

37 FASTLICHT, J. Crowding of mandibular incisors. Amer. J. Orthodont., v.58, n.4, p.156-63, July 1970.

38 FOSTER, T.D. A textbook of orthodontics. Oxford, Blackwell Scientific Publications, 1975, p.209-23. 
39 FOSTER, T.D., HAMiltON, M.C., LAVELLE, C.L. A study of dental arch crowding in four age groups. Dent. Pract. dent. Rec. ,v.21, n.1, p.9-12, Sept. 1970.

40 FREITAS, M.R.; HENRIQUES, J.F.C.; PINZAN, A. Estudo em modelos da recidiva do apinhamento ântero-inferior em pacientes tratados ortodonticamente, com extrações dos primeiros pré-molares, 5 e 10 anos pós-contenção. Ortodontia, v.29, n.1, p.19-30, jan./abr. 1996.

41 FIDLER, B.C., et al. Long-term stability of mandibular of Angle class II, dividion 1, malocclusions with successful occlusal results at end of active treatment. Amer. J. Orthodont. Dentofac. Orthop., v.107, n.3, p.276-85, Mar. 1995.

42 GARDNER, S.D.; CHACONAS, S.J. Posttreatment and postretention changes following orthodontic therapy. Angle Orthodont., v.46, n.2, p.151-61, Apr. 1976.

43 GEBECK, T.R.; MERRIFIELD, L.L. Orthodontic diagnosis and treatment analysis - concept and values: part II special article. Amer. J. Orthodont. Dentofac. Orthop, v.107, n.5, p.541-7, May 1995.

44 GEBECK, T.R.; MERRIFIELD, L.L. Orthodontic diagnosis and treatment analysis - concept and values: part I special article. Amer. J. Orthodont. Dentofac. Orthop., v.107, n.4, p.434-43, Apr. 1995. 
45 GLENN, G.; SINCLAIR, P.M.; ALEXANDER, R.G. Nonextraction orthodontic therapy: posttreatment dental and skeletal stability. Amer. J. Orthodont. Dentofac. Orthop., v.92, n.4, p.321-8, Oct. 1987.

46 GRABER, T.M. Current orthodontic concepts and techniques. Philadelphia, W.B. Saunders company, v.1, 988p.

47 GRABER, T.M. Maxillary second molar extraction in class II malocclusion. Amer. J . Orthodont., v.56, n.4, p. 331-53, Oct. 1969.

48 HAHN, G.W. Retention - the stepchild of orthodontia. Angle Orthodont., v.14, p.312, 1944.

49 HARUKI, T., LITTLE R.M. Early versus late treatment of crowded first premolar extraction cases: postretention evaluation of stability and relapse. Angle Orthodont., v.68, n.1, p.61-8, Feb.1998.

50 HERBERGER, R.J. Stability of mandibular intercuspid width after long periods of retention. Angle Orthodont., v.51, n.1, p.78-83, Jan. 1981.

51 HIME, D.L.; OWENS III, A.H. Stability of arch-expansion effects of Fränkel appliance therapy. Amer. J. Orthodont. Dentofac. Orthop., v.98, n.5, p.437-45, Nov. 1990 .

52 HOROWITZ, S.L.; HIXON, E.H. Physiologic recovery following orthodontic treatment. Amer. J. Orthodont., v.55, n.1, p.1-4, Jan. 1969.

53 HOUSTON, W.J.B. Analysis of errors in orthodontic measurements. Amer. J. Orthodont., v.83, n.5, p.382-90, May 1983. 
54 JANSON, G. Estudo tridimensional das assimetrias dentárias e esqueléticas na má oclusão de classe II subdivisão. Bauru, 1998. 271p. Tese (Livre Docência) - Faculdade de Odontologia de Bauru, Universidade de São Paulo.

55 JOHAL, A.S.; BATTAGEL, J.M. Dental crowding: a comparison of three methods of assessment. Europ. J. Orthodont., v.19, n.4, p.543-51, Oct.1997.

56 JOHNSON, K Cases six years postretention. Angle Orthodont., v.47, n.3, p.210-21, July 1977.

57 KAHL-NIEKE, B.; FISCHBACH, H.; SCHWARZE, C.W. Post-retention crowding and incisor irregularity: a long-term follow-up evaluation of stability and relapse. Brit. J. Orthodont., v.22, n.3 , p. 249-57, Aug. 1995.

58 KAHL-NIEKE, B.; FISCHBACH, H.; SCHWARZE, C.W. Treatment and postretention changes in dental arch width dimensions - a long-term evaluation of influencing cofactors. Amer. J. Orthodont. Dentofac. Orthop., v.109, n.4 , p.368-78, Apr . 1996.

59 KAPLAN, R. Mandibular third molars and postretention crowding. Amer. J. Orthodont., v.66, n.4, p.411-30, Oct. 1974.

60 LAMARQUE, S. The importance of occlusal plane control during orthodontic mechanotherapy - clinician's corner. Amer. J. Orthodont. Dentofac. Orthop., v.107, n.5, p.548-58, May 1988. 
61 LENZ, G.J.; WOODS, M.G. Incisal changes and orthodontic stability. Angle Orthodont., v.69, n.5, p.424-32, Oct. 1999.

62 LEWIS, E.A.. Reability and validity of clinical assessments of malocclusion.. Amer. J. Orthodont. , v.81, n.6, p.473-7, June 1982.

63 LISCHER, B.E. Principles and methods of orthodontics. Philadelphia, Lea \& Febiger, 1912.

64 LITT, et al. Class II division 2 malocclusion. To extract or not extract? Angle Orthodont., v.54, n.2, p.123-38, Apr.1984.

65 LITOWITZ, R. A study of the movements of certain teeth during and following orthodontic treatment. Angle Orthodont. v.18, n.3, p.113-31, 1948.

66 LITTLE, R.M. The irregularity index: a quantitative score of mandibular anterior alignment. Amer. J. Orthodont., v.68, n.5, p.554-63, Nov. 1975.

67 LITTLE, R.M.; WALlEN, T.; RIEDEL, R.A. Stability and relapse of mandibular anterior alignment-first premolar extraction cases treated by traditional edgewise orthodontics. Amer. J. Orthodont., v.80, n.4, p. 34965, Oct. 1981.

68 LITTLE, R.M.; RIEDEL, R.A. Postretention evaluation of stability and relapse - Mandibular arches with generalized spacing. Amer. J. Orthodont. Dentofac. Orthop. , v.95, n.1, p.37-41, Jan. 1989. 
69 LITTLE, R.M.; RIEDEL, R.A.; STEIN, A. Mandibular arch length increase during the mixed dentition: postretention evaluation of stability and relapse. Ame r. J. Orthodont. Dentofac. Orthop. , v.97, n.5, p. 393-404, May 1990.

70 LITTLE, R.M. Stability and relapse of mandibular anterior alignment: University of Washington studies. Brit. J. Orthodont., v.17, n.3, p.235-41, Aug. 1990.

71 LITTLE, R.M.; RIEDEL, R.A.; ENGEST, E.D. Serial extraction of first premolars - postretention evaluation of stability and relapse. Angle Orthodont., v.60, n.4, p.255-62, Winter 1990.

72 LITTLE, R.M.; RIEDEL, R.A.; ARTUN, J. Changes in mandibular anterior alignment 10 to 20 years postretention. Amer. J. Orthodont. Dentofac. Orthop., v.93, n.5, p.423-28. May 1988.

73 LITTLE, R.M. Stability and relapse of mandibular anterior alignment: University of Washington studies. Semin. Orthodont., v.5, n.3, p.191-204, Sept. 1999.

74 LOMBARDI, A.R. Mandibular incisor crowding in completed cases. Amer. J. Orthodont., v.61, n.4, p.374-83, Apr. 1972.

75 LUNDSTROM, A. Changes in crowding and spacing of the teeth with age. Dent. Pract., v.19, n.4, p. 218-24, 1968. 
76 LUPPANAPORNLARP, S.; JOHNSTON JÚNIOR, L.E. The effects of premolar-extraction: a long-term comparison of outcomes in "clear-cut" extraction and nonextraction class II patients. Angle Orthodont. , v.63 , n.4, p.257-72, Winter 1993.

77 McCAUley, D.R. The cuspid and its function in retention. Amer. J. Orthodont., v.30, n.3,p.196-205,1944.

78 MARGOLIS, H.I. The axial inclination of the mandibular incisors. Amer. J. Orthodont. oral Surg., v.29, n.10, p.571-91, Oct. 1943.

79 McDOWELL, C.S. Completing the patient in THIOP with no balancing interforces. J. clin. Orthodont., v.4, n.4, p.207-15, Apr. 1970.

80 McREYNOLDS, D.C.; LITTLE, R.M. Mandibular second premolar extractio postretention evaluation of stability and relapse. Angle Orthodont., v.61, n.2, p.133-44, Summer 1991.

81 MILLS, J.R.E. The long-term results of the proclination of lower incisors. Brit. Dent. J. v.120, n.8, p.355-63, Apr. 1966.

82 MIYAZAKI, H., et al. Occlusal stability after extraction orthodontics therapy in adult and adolescent patients. Amer. J. Orthodont. Dentofac. Orthop., v.114, n.5, p.530-7, Nov. 1998.

83 MOORREES, C.F.A.; CHADHA, M.J. Available space to the incisors during dental development, Angle Orthodont., v.35, n.1, p.12-22, 1965. 
84 MORO, A. Estudo da recidiva em pacientes com má oclusão de Classe II, tratados pela técnica do arco de canto com extrações de pré-molares pertencentes às categorias de crescimento de Petrovic. Bauru, 2001 306p. Tese (Doutorado) - Faculdade de Odontologia de Bauru, Universidade de São Paulo.

85 NANCE, H.N. The limitations of orthodontic treatment - Mixed dentition diagnosis and treatment. . Amer. J. Orthodont. oral Surg., v.33, n.3, p.177-223, 1947.

86 OLIVEIRA JÚNIOR, G. et al. Estudo da recidiva do apinhamento ânteroinferior de casos tratados com extrações de quatro primeiros pré-molares e mecânica do Arco de Canto. Ortodontia, v.24, n.1, p.24-30, jan./abr.1991.

87 OWMAN, G.; BJERKLIN, K., KUROL, J. Mandibular incisor stabilityafter orthodontic treatment in the upper arch. Europ. J. Orthodont., v.11, n.3, p.271-82, Aug.1989.

88 PARK, Y.C.; BURSTONE, C.J. Soft-tissue profile - fallacies of hard-tissue standards in treatment planning. Amer. J. Orthodont. Dentofac. Orthop., v.90, n.1, p.52-62, July 1986.

89 PAQUETTE, D.E.; BEATTIE, J.R.; JOHNSTON JÚNIOR., L.E. A long-term comparison of nonextraction and extraction edgewise therapy in borderline class II patients . Amer. J. Orthodont. Dentofac. Orthop., v.102, n.1, p.1-14, July 1992. 
90 PERSSON, M.; PERSSON E.C.; SKAGIUS, S. Long-term spontaneous changes following removal of all first premolars in class I cases with crowding. Europ. J. Orthodont., v.11, n.3 , p.271-82, May 1989.

91 PEAK, J.D. Cuspid Stability. Amer. J. Orthodont., v.42, n.7, p. 608-14 , July 1956.

92 PECK,S.; PECK, H. Crown dimension and mandibular incisor crowding. Angle Orthodont., v.42, n.2, p.148-53, Apr. 1972.

93 PETROVIC, A.; STUTZMANN, J. Aspectos referentes ao melhor momento para o tratamento ortodôntico. Ortodontia, v.26, n.1, p.4-13, jan./abr. 1993.

94 PROFFIT, W.R.; FIELDS, H.W. Ortodontia contemporânea. Rio de Janeiro, Guanabara-Koogan, 1995, 2.ed., 596 p.

95 PUNEKY, P.J.; SADOWSKY, C.; BEGOLE, E.A. Tooth morphology and lower incisor alignment many years after orthodontic therapy. Amer. J. Orthodont., v.86, n.4, p.299-305, Oct., 1984.

96 REITAN, K. Clinical and histologic observations on tooth movement during and after orthodontic treatment. Amer. J. Orthodont., v.53, n.10, p.72145, Oct. 1967.

97 RICHARDSON, M.E. Late lower arch crowding: the role of differential horizontal growth. Brit. J. Orthodont., v.21, n.4, p.379-85, Nov. 1994. 
98 RICHARDSON, M.E. The etiology of late lower arch crowding alternative to mesially directed forces: a review. Amer. J. Orthodont. Dentofac. Orthop., v.105, n.6, 592-7, June 1994.

99 RICHARDSON, M.E. A review of changes in lower arch alignment from seven to fifty years. Semin. Orthodont., v5, n.3, p.151-9, Sept. 1999.

100 RIEDEL R.A.; LITTLE R.M.; BUI T.D. Mandibular incisor extraction postretention evaluation of stability and relapse. Angle Orthodont., v.62, n.2, p.103-16, Summer 1992.

101 ROCKE, R.T. An American Board of Orthodontics case report. Amer. J. Orthodont. Dentofac. Orthop., v.100, n.1, p.84-90, July 1991.

102 ROSSOUW, P.E., et al. A longitudinal evaluation of the anterior border of dentition. Amer. J. Orthodont. Dentofac. Orthop., v.104, n.2, p.146-52, Aug. 1993.

103 RUBIN, R.M. Comments on high angle Class II cases.. Amer. J. Orthodont. Dentofac. Orthop., v.101, n.3, p. 22A-4A, July 1992.

104 SALZMANN, J.A. Practice of orthodontics. Philadelphia, J.B. Lippincott Company, 1966, v.2, p.701-24.

105 SADOWSKY, C.; SAKOLS, E.I. Long-term assessment of orthodontic relapse. Amer. J. Orthodo nt. , v.82, n.6 , p.456-63, Dec. 1982. 
106 SADOWSKY C., et al. Long-term stability after orthodontic treatment: Nonextraction with prolonged retention. Amer. J. Orthodont. Dentofac. Orthop., v.106, n.3, p. 243-49, Sept.1994.

107 SANDSTROM, R.A.; KLAPPER, L.; PAPACONSTANTINOU, S. Lower arch expansion concurrent with rapid maxillary expansion. Amer. J. Orthodont. , v.94 , n.4 , p.296-302, Oct.1988.

108 SHAPIRO, P.A. Mandibular dental arch form and dimension _ treatment and postretention changes. Amer. J. Orthodont, v.66, n.1, p.58-70, July 1974.

109 SHERIDAN, J.J. Air-rotor stripping. J. clin. Orthodont. v.19, n.1, p.43-59, Jan. 1985.

110 SHERIDAN, J.J. Air-rotor stripping update. J. clin. Orthodont. v.21, n.11, p.781-8, Nov. 1987.

111 SHERIDAN, J.J; HASTING, J. Air-rotor stripping and lower incisor extraction treatment. J. clin. Orthodont. v.36, n.1, p18-24, Jan. 1992.

112 SHEPARD, E.E. The philosophy of the twin wire appliance. Amer. J. Orthodont. V.55, n.6, p.688-704, June 1969.

113 SHIELDS T., LITTLE R., CHAPKO M. Stability and relapse of mandibular anterior alignment: a cephalometric appraisal of first premolar extraction cases treated by traditional edgewise orthodontics. Amer. J. Orthodont. v.87, n.1, p.27-38, Jan. 1985. 
114 SILLMAN, J.H. Dimensional changes of the dental arches: longitudinal study from birth to 25 years. Amer. J. Orthodont. v.50, n,11, p.824-41, 1964.

115 SINCLAIR, P.M.;LITTLE, R.M. Maturation of untreated normal occlusion. Amer. J. Orthodont., v.83, n.2, p. 114-23, Feb. 1983.

116 SONDHI, A.; CLEALL, J.F.; BEGOLE, E.A. Dimensional changes in the dental arches of orthodontically treated cases. Amer. J. Orthodont., v.77, n.1, p.60-74, Jan. 1980.

117 SOUTHARD, T.E.; BEHRENTS, R.G.; TOLLEY, E.A. The anterior component of occlusal force - Part 2: Relationship with dental malalignment. Amer. J. Orthodont. Dentofac. Orthop., v.97, n.1, p.41-4, Jan. 1990.

118 STEADMAN, R.S. Changes of intermolar and intercuspid distances following orthodontic treatment. Angle Orthodont., v.31, n.4, p.207-15, Oct. 1961.

119 STRANG, R.H.W. The fallacy of denture expansion as a treatment procedure. Angle Orthodont., v.19, n.1, p.12-22, Jan. 1949.

120 STRANG, R.H.W. Factors of influence in producing a stable result in the treatment malocclusion.. Amer. J. Orthodont. oral Surg. , v.32, p.31332, 1946.

121 SWANSON, W.D.; RIEDEL, R.A.; D`ANNA, J.A. Postretention study: incidence and stability of rotated teeth in humans. Angle Orthodont. , v.45, n.3, p.198-203, July 1975. 
122 TANG, E.L.K.; WEI, S.H.Y. Recording and measuring malocclusion. Amer.

J. Orthodont. Dentofac. Orthop., v.103, n.4, p.344-51, Apr. 1993.

123 TERRY, H.K. The labiolingual appliance. Amer. J. Orthodont. , v.55, n.6, p.714-33, 1969.

124 THILANDER, B. Biological basis for orthodontic relapse. Semin. Orthodont., v.6, n.3, p.195-205, Sept. 2000.

125 TOIGO, E.; MANDETTA, S. Estudo das alterações das dimensões e formas dos arcos dentários, ocorridas no final e cinco anos pós-tratamento, em pacientes com má oclusão de classe II, divisão 1, tratados com extrações de pré-molares pela técnica de arco de canto. Ortodontia, v.33, n.2, p.2035, maio/ago. 2000.

126 TUlLEY, W.J.; CAMPBELL A.C. A manual of practical orthodontics. Bristol, John Wright and Sons., p.203-10; 218-21. 1965.

127 TWEED, C.H. Indication for extraction of teeth in orthodontic procedures. Postretention study: incidence and stability of rotated teeth in humans. Amer. J. Orthodont. oral Surg. , v.30, p.405-28, 1944.

128 TWEED, C.H. The application of the edgewise arch in the treatment of malocclusions: Part II. Angle Orthodont. , v.11, n.1, p.12-67, Jan. 1941.

129 UHDE, M.D.; SADOWSKY, C.; BEGOLE E.A. Long-term stability of dental relationships after orthodontic treatment. Angle Orthodont. , v.53, n.3, p. 240-52, July 1983. 
130 VADEN, J.L.; HARRIS, E.F.; BEHRENTS, R.G. Adult versus adolescent Class II correction: a comparison- case report. Amer. J. Orthodont. Dentofac. Orthop., v.107, n.6. p.651-61, June 1997.

131 VADEN, J.L.; HARRIS, E.F.; GARDNER, R.L.Z. Relapse revisited . Amer. J. Orthodont. Dentofac. Orthop., v.111, n.5, p.543-553, May 1997.

132 VADEN, J.L.; KISER, H.E.. Straight talk about extraction and non-extraction: a differential diagnostic decision. Amer. J. Orthodont. Dentofac. Orthop., v.109, n.4, p.445-52, Apr. 1996.

133 WALTER D.C. Changes in the form and dimensions of dental arches resulting from orthodontic treatment. Angle Orthodont., v.23, n.1, p.3-18, 1953.

134 WEILAND, F.J. The role of occlusal discrepancies in the long-term stability of the mandibular arch. Europ. J. Orthodont., v.16, n.6, p.521-9, Dec. 1994.

135 WILIAMS, S.; ANDERSEN, C.E. Incisor stability in patients with anterior rotational mandibular growth. Angle Orthodont, v.65, n.6, p. 431-42, 1995.

136 WOODSIDE D.G.; ROSSOUW, P.E.; SHEARER, D. Postretention mandibular incisor stability after premolar serial extractions. Semin. Orthodont. , v.5, n.3, p.181-90. Sept. 1999.

137 YAMAGUCHI, K.; NANDA, R.S. The effects of extraction and nonextraction treatment on the mandibular position. Amer. J. Orthodont. Dentofac. Orthop., v.100, n.5, p.443-52, Nov.1991. 
Abstract 


\begin{abstract}
STABILITY OF THE LOWER ANTERIOR CROWDING CORRECTION, IN

ANGLE CLASS II MALOCCLUSION PATIENTS TREATED WITH TWO

AND FOUR PREMOLARS EXTRACTIONS.
\end{abstract}

The purpose of this research was to compare the relapse of the lower anterior teeth's crowding corrrection in patients with Class II malocclusions, that were treated with either, two or four premolar extraction therapies. Group 1 consisted of 19 patients ( 9 boys e 10 girls) treated with two premolar extraction, and group 2 consisted of 47 patients (20 boys e 27 girls) treated with four premolar extraction. The initial mean age of the first group was 14,04 years, and the initial mean age for group two was 13,03 years. Little's Irregularity Index was used to assess the crowding in the pre-treatment, end of active treatment and five years posttreatment diagnostic casts of each case. Individual variables of the mandibular arch, such as intercanine width, intermolar width and arch lenght, were also evaluated. Independent $t$ tests were used to compare the differences of the variables between the groups. Results demonstrated that there were no statistically significant difference between the incisor alignment relapse in the groups. Also the posttreatmet constriction of the mandibular arch (width and lenght), was statistically the same for both groups. Therefore, it was concluded that the treatment of Class II malocclusion with two premolar extraction, provides the same stability for lower incisor's irregularity corrrection, as the treatment with four premolar extraction. 
Apêndice 


\section{Universidade de São Paulo Faculdade de Odontologia de Bauru}

Al. Dr. Octávio Pinheiro Brisolla, 9-75 - Bauru-SP - CEP 17012-901 - C.P. 73

PABX (0XX14)235-8000 - FAX (0XX14)223-4679

Comitê de Ética em Pesquisa

Processo nO ODON-3042002

Bauru, 25 de abril de 2002.

Senhor Professor,

O projeto de pesquisa encaminhado a este Comité de Ética denominado "Estabilidade da correção do apinhamento ântero-inferior na má oclusão de Classe II de Angle tratada com extração de dois e quatro pré-molares", que será desenvolvido por Mauro Carlos Agner Busato sob a orientação ", foi enviado ao relator para avaliação".

Na reuniäo de 24 de abril, o parecer do relator, aprovando o projeto, foi aceito pelo Comitê, considerando que não existem infraçőes éticas pendentes.

Informamos que após o envio do trabalho concluído, este comitê enviará o parecer final que será utilizado para publicaçăo do trabalho.

Atenciosamente,

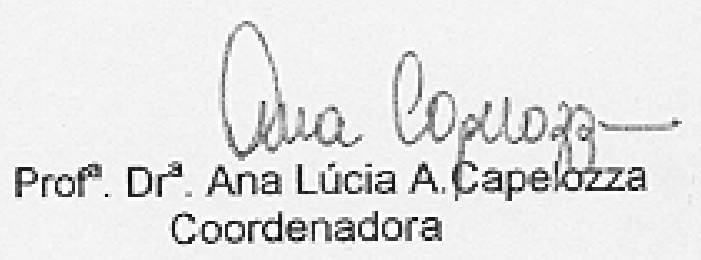

II.mo.Senhor

Prof Dr Guilherme dos Reis Pereira Janson. 